\title{
Biotic and Abiotic Interactions of Deep-Sea Hydrothermal \\ Vent-Endemic Fish on the East Pacific Rise
}

\author{
By
}

\author{
Kate Lynn Buckman
}

B.A., Smith College, 2001

Submitted in partial fulfillment of the requirements for the degree of

Doctor of Philosophy

at the
MASSACHUSETTS INSTITUTE OF TECHNOLOGY
and the

WOODS HOLE OCEANOGRAPHIC INSTITUTION

September 2009

(C) 2009 Kate L. Buckman

All rights reserved.

The author hereby grants to MIT and WHOI permission to reproduce and to distribute publicly paper and electronic copies of this thesis document in whole or in part in any medium now known or hereafter created.

Signature of Author

$$
\text { ก } \cap
$$

Joint Program in Oceanography/Applied Ocean Science and Engineering Massachusetts Institute of Technology and Woods Hole Oceanographic Institution

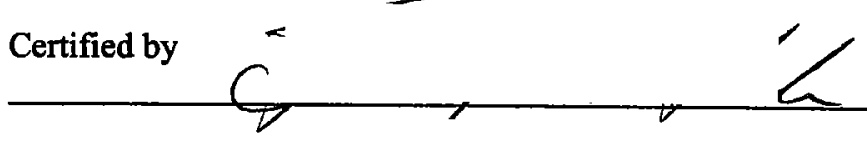

10 August 2009

Accepted by

)

Dr. Timothy M. Shank Thesis Supervisor

Dr. Simon R. Thorrold Chair, Joint Committee for Biology 


\section{Grampy and Karen}

who believed that I could do it,

but didn't get to see me finish;

and for

my Family

who just want me to be happy. 


\title{
Biotic and Abiotic Interactions of Deep-Sea Hydrothermal
}

\author{
Vent-Endemic Fish on the East Pacific Rise
}

\author{
By \\ Kate Lynn Buckman \\ Submitted to the Department of Biology \\ on 10 August 2009, in partial fulfillment of the \\ requirements for the degree of Doctor of Philosophy
}

\begin{abstract}
A study of the ecology of fish endemic to hydrothermal vents on the East Pacific Rise was undertaken utilizing a variety of techniques, focusing on the bythitid Thermichthys hollisi. Stable isotope and gut content analyses were used to elucidate prey choice and trophic relationships. Otolith chemical signatures were investigated to determine whether this technique could be utilized to examine life history strategy and habitat use.

Chemical characteristics of preferred fish habitat and gene expression responses habitat chemistry were explored. Gut contents indicated that $T$. hollisi specimens were actively feeding upon a combination of brachyuran crabs, Alvinocaris shrimp, polychaetes, and zoarcid fish with the majority of fish containing evidence of crustacean prey. Carbon, nitrogen, and sulfur stable isotopic measurements support a chemosynthetically based prey source and place $T$. hollisi in the uppermost trophic levels of vent communities. The influence of exposure to hydrothermal fluids was apparent in otoliths from both species of vent fish, most noticeably within the relatively elevated $\mathrm{Sr}: \mathrm{Ca}$ and depleted $\mathrm{Mg}: \mathrm{Ca}$ ratios. Otolith chemistry suggested that the zoarcid Thermarces cerberus experiences greater direct exposure to diffuse fluids than does $T$. hollisi, which is concurrent with apparent habitat preferences. Isotopic patterns across the span of the otolith suggested that $T$. cerberus spends its entire life within the vent system. In contrast, it appeared that T. hollisi exists outside of the influence of hydrothermal activity for some early portion of its life-cycle. Time-lapse photography and in situ electrochemistry indicated that $T$. hollisi are preferentially utilizing fish holes where there are elevated temperatures and sulfide levels, and variable oxygen levels in comparison to ambient bottom water. A fragment of $\mathrm{Cu}, \mathrm{Zn}$ superoxide dismutase was successfully amplified from $T$. hollisi mRNA, but there were no differences in expression levels between tissue types or among individuals within the small sample examined. In general, it appears that $T$. hollisi is both influenced by and may exert a greater influence on hydrothermal vent communities to a greater degree than initially hypothesized.

Thesis Supervisor: Timothy M. Shank

Title: Associate Scientist, Biology Department, Wood Hole Oceanographic Institution
\end{abstract}




\section{Acknowledgements}

This thesis could not have been accomplished without the support of a variety of people who have been there for me both personally and professionally throughout the past six years. My advisor, Tim, has provided me with innumerable opportunities to expand my horizons, and has always allowed me the freedom to pursue my own interests, even if the road I wanted to go down was not what many would have viewed as the logical choice. When he realized that yes, I really only wanted to work on fish, he helped make that dream a reality. He and the rest of my committee: Simon, Mark, Leona, and George, have always been helpful, supportive, and willing to answer any questions that I might have for them, even if it was not their area of expertise, and for that I thank them.

My lab has seen a constant flow of students, volunteers, and guests throughout my time at WHOI, and I have always enjoyed and benefitted from my interactions with them. Abby, Walter, and Diane provided great support as we all struggled to figure out graduate school and life as scientists, and were always willing to lend a hand or an ear at sea or in the lab. Rhian has proved to be a steadfast and true friend from the very beginning, and I'm not sure what I would have done without her support and encouragement. Breea can always be counted on for an intellectual discussion, a compassionate ear, or a good laugh; she always seems to know what is needed. There are too many more to name individually, but members of the Shank Lab, I thank you for your help and enthusiasm over the years.

I was privileged to spend a substantial amount of time at sea as a graduate student, and field work remains one of my chief joys as a scientist. I cannot express enough how grateful I am to the crew of the Atlantis and the members of the Alvin group that I have worked with over the years for helping me with my research, and for being good shipmates and good friends. Jay Burnett, Waldo Wakefield, Harvey Walsh and Scot Birdwhistell provided valuable samples, support, time, and discussion.

My fellow JP students form a community that is truly special, and I thank them all for their uniqueness and passion. The 2003 cohort of biologists, Ari, Annette, Adam, Sarah, and Stacy has been through it all together, and survived. Liz, Dreux, Mike, Annette and Louie have all provided intellectual and emotional support, especially with the dratted pcr. Words cannot adequately define the quality of friends I have found in Annette, Dreux, Liz, Liz, Katie, Rhian and Chris. I would not have made it through grad school without them. I am also eternally grateful to Dan and CL and Breck and BL for taking me into their homes and making me a part of their families. For all those who I have inadvertently omitted, know that your friendship and encouragement has been appreciated.

Support for my graduate research and education came from a variety of sources and the work contained within could not have been completed without their generous aid. I was the recipient of a 2003 MIT Presidential Fellowship, a 2004-2007 National Defense 
Science and Engineering Graduate Fellowship, and received support from the Woods Hole Oceanographic Institution Academic Programs Office as well as National Science Foundation's Office of Polar Programs (ANT-073965) support to TMS. Funding for my research was provided in part by the National Science Foundation (OCE-032726 and OCE-0324232), the National Oceanic and Atmospheric Administration's Office of Ocean Exploration and Research (Award Nos. NA03OAR4600110, NA16RP2390, and NA 04OAR4600049) support to TMS and a 2008 Lerner-Gray Grant for Marine Research from the Lerner Gray Memorial Fund of the American Museum of Natural History support to KLB.

And last, but always first in my heart, I would like to thank my family for their unwavering love, encouragement, and faith in me. They have supported me in every endeavor and provided me with every opportunity to foster my interests and passions throughout my whole life. They make every trip home something to look forward to, have always expressed interest in my work, and make me want to make them proud. It is because of their humor, intelligence, tolerance, integrity, uniqueness and love that I have made it this far. Mom, Pop, Andy, Gram, and Grampy and our myriad of furry family; thanks, and I love you. 


\section{TABLE OF CONTENTS}

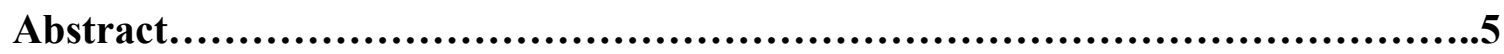

Chapter 1 An introduction to Hydrothermal vents and their associated Fish

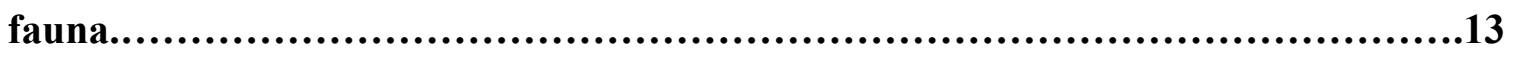

$\begin{array}{ll}\text { Section } 1.1 \text { Hydrothermal Vents } & 13\end{array}$

Section 1.2 East Pacific Rise 15

Section 1.3 Vent Vertebrates $\quad 19$

Section 2.4 Goals of Thesis 23

References 25

Chapter 2 Trophic Ecology of the Hydrothermal Vent Fish Thermichthys

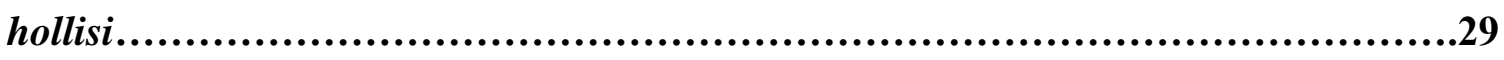

Section 2.1 Introduction $\quad 29$

2.1.1 Fish at Hydrothermal Vents 31

2.1.2 Gut content and Stable Isotope Dynamics 35

2.1.3 Stable Isotope Studies at Hydrothermal Vents 37

Section 2.2 Methods 39

2.2.1 Specimen Collection and Sample Sites 39

2.2.2 Gut Content Analysis $\quad 44$

2.2.3 Stable Isotope Analysis 45

Section 2.3 Results 47

2.3.1 Gut Content Analyses 47

2.3.2 Isotope Analyses 51

$\begin{array}{ll}\text { Section 2.4 Discussion } & 60\end{array}$

References $\quad 66$ 
Chapter 3 Otolith Isotope Chemistry of Hydrothermal Vent Fish: Insights into Habitat Use and Life History

Strategy...................................................................... 71

$\begin{array}{ll}\text { Section 3.1 Introduction } & 71\end{array}$

$\begin{array}{ll}\text { Section 3.2 Methods } & 79\end{array}$

3.2.1 Otolith processing 79

3.2.2 ICPMS Analysis $\quad 80$

Section 3.3 Results 83

Section 3.4 Discussion 96

$\begin{array}{ll}\text { References } & 105\end{array}$

Chapter 4 A preliminary exploration of gene expression in the hydrothermal vent

fish Thermichthys hollisi.................................................... 107

$\begin{array}{ll}\text { Section 4.1 Introduction } & 107\end{array}$

$\begin{array}{ll}\text { Section 4.2 Methods } & 110\end{array}$

4.2.1 Fish Collection and Preservation 110

4.2.2 Electrochemical Measurements 111

4.2.3 Time Lapse Photography 112

4.2.3 RNA Extraction and RT-PCR 116

$\begin{array}{ll}\text { Section } 4.3 \text { Results } & 120\end{array}$

4.3.1 Electrochemical measurements $\quad 120$

4.3.2 Image analysis 124

4.3.3 Gene expression and relationship 125

$\begin{array}{ll}\text { Section 4.4 Discussion } & 131\end{array}$

$\begin{array}{ll}\text { References } & 136\end{array}$

Chapter 5 Summary of Findings...................................................141

$\begin{array}{ll}\text { References } & 147\end{array}$ 


\section{List of Figures}

1.1 Global vent locations 17

$1.2 \quad 9^{\circ} \mathrm{N}$ segment of the East Pacific Rise 18

2.1 Typical habitats of Thermarces cerberus and Thermichthys hollisi 34

2.2 Suction sampler 41

$2.3 \quad 9^{\circ} \mathrm{N}$ segment of the East Pacific Rise with major sampling locations $\quad 42$

2.4 Image of polychaete chaetae 49

2.5 Image of crustacean exoskeleton from gut contents $\quad 50$

2.6 Image of shrimp and zoarcid from gut contents 50

2.7 Uncorrected and lipid-normalized carbon isotopic values for fish tissues 53

2.8 Stable isotope values from L vent fauna 54-55

2.9 Potential trophic levels as indicated by stable isotope data 56

2.10 Stable isotope values for all data $\quad$ 57-58

2.11 Isosource output for T. hollisi liver data 59

$\begin{array}{ll}2.12 & \text { Hypothesized trophic network at vents }\end{array}$

$3.1 \quad$ Otolith within fish 81

3.2 Polished otolith example $\quad 82$

3.3 Ablated otolith example 82

3.4 Box plot of $\mathrm{Li}: \mathrm{Ca}, \mathrm{Ba}: \mathrm{Ca}, \mathrm{Sr}: \mathrm{Ca}$ and $\mathrm{Mg}: \mathrm{Ca}$ data from all fish types $\quad 86$

3.5 Box plot of $\mathrm{Cd}$ :Ca and some rare earth elements for vent fish 87

3.6 Box plot of elements present in 50-90\% of non-vent samples 88

$\begin{array}{lll}3.7 & \text { Li:Ca otolith data } & 89\end{array}$

$\begin{array}{lll}3.8 & \text { Sr:Ca otolith data } & 90\end{array}$

3.9 Cd:Ca otolith data 91

$\begin{array}{lll}3.10 & \text { Ba:Ca otolith data } & 92\end{array}$

$3.11 \mathrm{Mg}:$ Ca otolith data 93

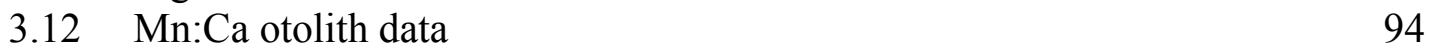

3.13 Rare earth element otolith data 95

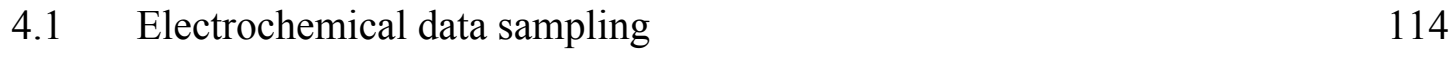

$\begin{array}{lll}4.2 & \text { Time-lapse camera system on seafloor } & 114\end{array}$

4.3 Example of time-lapse photo of fish hole 115

$\begin{array}{lll}4.4 & \text { E-chem temperature data } & 121\end{array}$

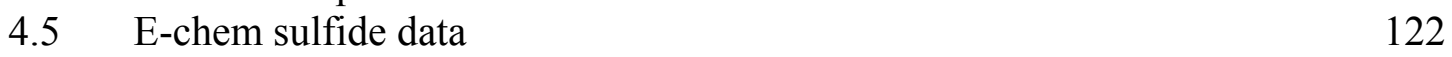

$\begin{array}{lll}4.6 & \text { E-chem oxygen data } & 123\end{array}$

$\begin{array}{lll}4.7 & \text { Image analysis fish abundance data } & 124\end{array}$

$\begin{array}{lll}4.8 \mathrm{Cu}, \mathrm{Zn}-\mathrm{SOD} \text { protein alignment } & 127\end{array}$

$4.9 \mathrm{Cu}, \mathrm{Zn}$-SOD nucleotide neighbor-joining tree 128

$4.10 \mathrm{Cu}, \mathrm{Zn}$-SOD amino acid neighbor-joining tree 129

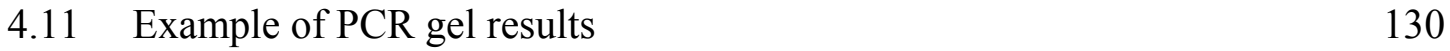

$\begin{array}{ll}4.12 \text { Relative SOD expression } & 130\end{array}$

$\begin{array}{lll}5.1 & \text { Summary figure } & 143\end{array}$ 


\section{List of Tables}

2.1 Example of effect of predatory fish on surrounding ecosystem 31

2.2 Mean isotopic values for all samples 43

2.3 Gut content results 48

3.1 Element abundances in hydrothermal vent fluids $\quad$ 75-77

4.1 All primers tested and BLAST results 118

$\begin{array}{lll}4.2 & \text { T. hollisi primers } & 119\end{array}$ 


\section{Chapter One}

\section{An Introduction to Hydrothermal Vents and their associated Fish fauna}

\subsection{Hydrothermal Vents}

Deep-sea hydrothermal vents exist throughout the global ocean at tectonically and volcanically-active mid-ocean spreading centers and subduction zones, where nutrientrich fluids emanate from the seafloor (Figure 1.1). Vent ecosystems occur in a variety of geological settings and support communities based on chemoautotrophic primary production. Vent biological communities were discovered in 1977 at the Galápagos rift, with the discovery of black smokers and their associated fauna on the East Pacific Rise following shortly after (Lonsdale, 1977; Ballard \& Grassle, 1979). This discovery changed the face of deep-sea research, leading to a greater understanding of the heat fluxes, element cycling, geology, chemistry, and biology of the deep ocean.

Hydrothermal fluids are generated when seawater percolates down through the porous oceanic crust, is heated by proximity to magma chambers, and subsequently altered through water-rock reactions. The resultant hydrothermal fluids are typically hot, acidic, enriched in sulfides and a variety of other elements and elemental compounds (strontium, cadmium, iron, lithium) and depleted in magnesium (Edmond et al., 1982; Von Damm, 1995). The hot, buoyant fluids rise up through the crust and are discharged through high-temperature direct flow chimneys (Haymon et al., 1993) or can mix with seawater subsurface and trickle out through cracks or porous substrates as diffuse flow (Edmond et al., 1979). The mixing of super-heated hydrothermal fluids with seawater 
causes metal sulfides and minerals to precipitate and form the distinctive and picturesque sulfide chimneys that are the conduits of high-temperature fluids. Lower-temperature diluted or diffuse flow fluids maintain a chemical composition distinct from that of seawater. Chemical species such as hydrogen sulfide and methane within these fluids support the chemosynthetic-based biological communities that are found in conjunction with active venting (Jannasch, 1979; Johnson et al., 1988). Though the presence of hydrothermal fluids is necessary for endemic life at vents, prolonged exposure to components of the fluids may simultaneously be stressful or harmful for the vent macrofauna. Numerous studies have been dedicated to studying the biology of various vent fauna and the diverse physiological and ecological adaptations these fauna have to their environment (Childress \& Fisher, 1992; Hourdez \& Lallier, 2007).

\subsection{East Pacific Rise}

This thesis focuses on the resident biological communities of the fast-spreading East Pacific Rise (EPR). Basalt-hosted hydrothermal vents such as those on the EPR are characterized by hot $\left(2-400^{\circ} \mathrm{C}\right)$, acidic ( $\left.\mathrm{pH} \sim 2-5.6\right)$, heavy metal and sulfide (3$110 \mathrm{mmol} / \mathrm{kg} \mathrm{H}_{2} \mathrm{~S}$ ) rich fluids, though the actual fluid composition varies both spatially and temporally (Johnson et al., 1988; Van Dover, 2000; Kelley et al., 2002). The greatest abundance and diversity of vent faunal species is located in lower temperature diffuse flow areas. Diffuse flow fields have cooler fluids (usually lower than $30^{\circ} \mathrm{C}$ ), containing lower concentrations of sulfides and metals than direct flow environments such as black smokers (Kelley et al., 2002). Along with sulfides, other key fluid components are 
methane $\left(\mathrm{CH}_{4}\right)$, hydrogen $(\mathrm{H})$, and metals such as copper $(\mathrm{Cu})$, iron $(\mathrm{Fe})$, manganese (Mn), and lead $(\mathrm{Pb})$ (Van Dover, 2000; Kelley et al., 2002). The seawater provides organisms with oxygen, while the hydrothermal fluid provides the necessary substrates $\left(\mathrm{H}_{2} \mathrm{~S}, \mathrm{CH}_{4}\right)$ for chemosynthesis. In part, the degree of mixing and exposure to venting fluid in conjunction with individual species physiologies determines whether or not an organism is able to exist in these habitats (Luther et al, 2001).

The focus of this study, the $9^{\circ} 45-50^{\prime} \mathrm{N}$ segment of the EPR (Figure 1.2), has been studied extensively. Two known eruptive events, one in April of 1991 (Haymon et al., 1991; Haymon et al., 1993; Von Damm et al., 1995) and another in late 2006 (Tolstoy et al., 2006; Soule et al., 2007), have been observed, allowing for a greater understanding of the geological, chemical and biological interactions at vents, as well as providing a unique opportunity to observe biological succession in the vent ecosystem following a catastrophic event. In 1991 the high temperature fluids immediately following the eruption were high in sulfide $(41 \mathrm{mmol} / \mathrm{kg})$, carbon dioxide $(15.5 \mathrm{mmol} / \mathrm{kg})$, and methane $(0.19 \mathrm{mmol} / \mathrm{kg})$ (Von Damm, 2000; Lilley and Olson, 2001). These values decreased as time post-eruption increased, forming a temporally and spatially diverse patchwork of chemistries within the region, yet all vent fluids remained elevated in basic properties relative to non-vent deep-sea environments.

Just as the age of a vent field influences fluid chemical composition, it also affects community composition and abundance. On the EPR, successionally younger biological communities are initially dominated by Tevnia tubeworms, but soon become overtaken by Riftia tubeworms. Older communities and areas where flow conditions tend to be less 
vigorous host bathymodiolid mussels and vesicomyid clams (Shank et al., 1998). All of the above mentioned organisms are primarily if not totally dependent upon a symbiosis with chemoautotrophic symbionts for nutrition. These structural species provide habitat for a suite of other vent-endemic fauna such as limpets, amphipods, crabs, polychaetes, and fish that may or may not directly utilize chemoautotrophic microbes for nutrition, but are ultimately dependent upon this carbon fixation process for sustenance (Govenar et al., 2005).

Chemosynthetic production forms the base of all trophic interactions within the system, and it is unusual for non-vent fauna to take advantage of the high productivity and large biomass present within a vent field. This may in part be due to an inability of non-vent fauna to adapt to and offset the affects of the shifting and potentially harmful chemical environment, including potential prey items that may be unpalatable or unsafe due to their habitat and physiology (Childress \& Fisher, 1993; Kicklighter et al., 2004). All vent fauna have some sort of adaptation to meet the challenges present within their habitat, including the presence of high levels of hydrogen sulfide, high concentrations of heavy metals, and low levels of oxygen, all of which can be toxic. Vent fauna are uniquely suited to deal with these challenges, utilizing behavioral, structural, metabolic, and even gene level adaptations to allow them to survive and thrive. For example, the tubeworm Riftia has a unique hemoglobin that allows for the simultaneous transfer of hydrogen sulfide for the symbiont and oxygen for the host (Arp \& Childress, 1983; Zal et al., 1998). Some organisms have enzymes that are able to function at higher 


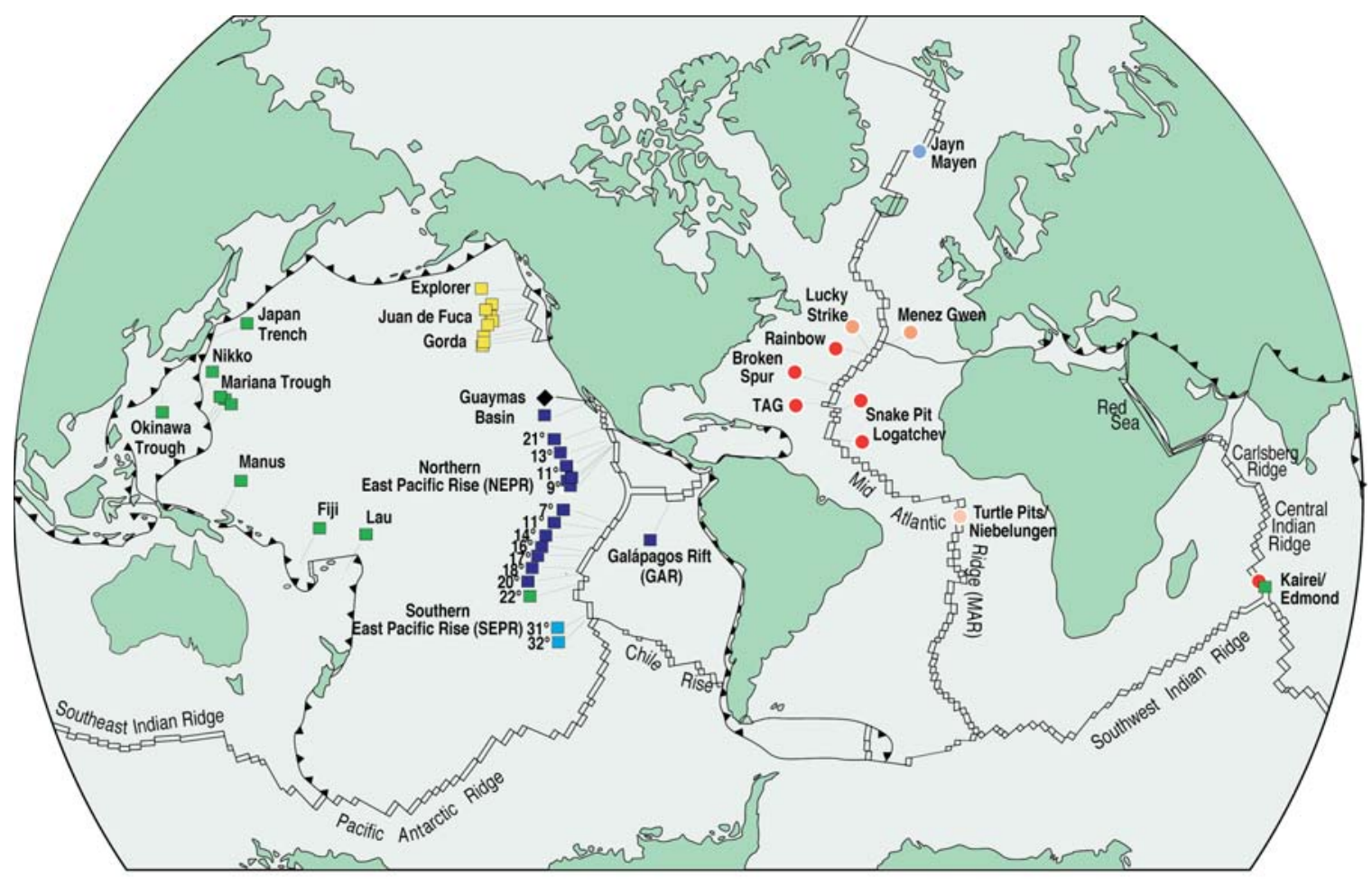

Figure 1.1 Areas of known venting around the world. 


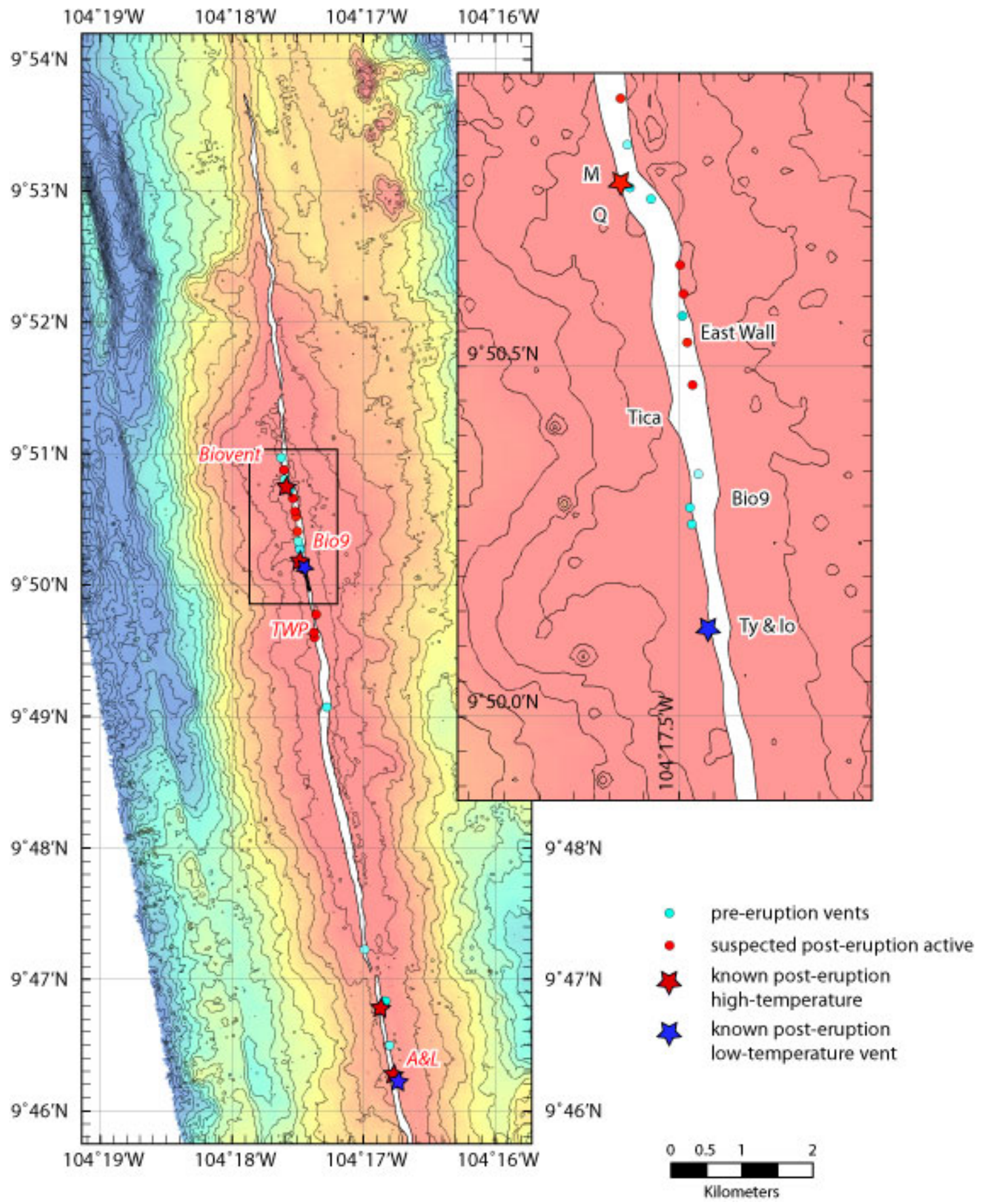

Figure $1.29^{\circ} \mathrm{N}$ segment of the East Pacific Rise with known pre- and post-eruption (2006) vent sites indicated. The enlarged box encompasses the BioGeoTransect. 
temperatures than the same enzyme in non-vent fauna (Dahlhoff \& Somero, 1991). Paralvinella grasslei, a polychaete worm, is thought to shed potential toxins such as sulfides along with its mucous, and numerous other behavioral and physiological adaptations of vent fauna have been examined (Van Dover, 2000). Despite the growing body of knowledge regarding vent-endemic invertebrate adaptations, life histories, and community dynamics, little is known regarding the ecology of fish species who are also important member of these deep-sea communities.

\subsection{Vent Vertebrates}

To date numerous fish species have been observed in association with hydrothermal vents worldwide (Geistdoerfer, 1996; Tunnicliffe, 1991), though a lack of captured specimens has made comprehensive species identifications difficult to achieve. Desbruyères et al. (2006) list nineteen species of fish from ten families as being associated with hydrothermal venting worldwide, with at least another six species waiting description. Of the nineteen listed, nine are considered endemic to hydrothermal vents. Individual species from the family Zoarcidae dominate both the associated fauna and endemic fauna categories (Biscoito et al., 2002). Along the Mid-Atlantic Ridge, the zoarcid Pachycara thermophilum is most commonly observed at vent communities while species such as the morid Lepidion schmidti have been seen in proximity to venting areas, but are likely not dependent exclusively upon vent ecosystems for either food or habitat (Geistdoerfer, 1994; Saldanha \& Biscoito, 1997). Similarly, on the EPR, a number of species have been observed near vents, including liparids, macrourids, synaphobranchids, 
and ophidiids, but only two (with a potential third) are currently considered endemic to the chemosynthetic communities (Desbruyères et al., 2006). These are the zoarcid Thermarces cerberus (Rosenblatt \& Cohen, 1986) and the bythitid Thermichthys hollisi (Cohen et al., 1990). While considerably more research has focused on understanding vent invertebrate communities and adaptations to the environment, there is some general knowledge regarding these two species of vent-endemic fish.

Thermarces cerberus is a member of the family Zoarcidae, commonly called eelpouts. Zoarcid individuals are often rare, though this family has been highly successful at colonizing the deep continental shelves of northern-hemispheric oceans (Anderson, 1994). At vents, T. cerberus is typically found in diffuse flow areas colonized by tubeworms or mussels, with numerous individuals residing amongst the tubeworm tubes (Geistdoerfer \& Seuront, 1995). A similar species (Thermarces andersoni Rosenblatt \& Cohen, 1986) has also been described from Pacific vents, but it is unclear whether the two are actually separate species. Numerous small and presumably young zoarcid individuals were observed after both the 1991 and 2006 eruptions (Shank et al., 1998; pers. obs.). T. cerberus is known to prey mainly upon limpets and small crustaceans with a preference shown for the large lepetodrilid limpet individuals (Sancho et al., 2005), while Pond et al. (2008) found that T. cerberus fatty acid signatures were consistent with a diet composed of vent invertebrates. Exclusion studies suggest that $T$. cerberus may play a role in structuring the invertebrate community composition through their selective predation (Micheli et al., 2002). They are thought to be potentially welladapted to exposure to warm diffuse fluids as their lactate dehydrogenase has a higher 
functional temperature tolerance than that of most other deep-sea fish, including the other vent endemic species along the EPR, Thermichthys hollisi (Dahlhoff et al., 1990).

Less is known regarding the ecology of the bythitid Thermichthys hollisi. The family Bythitidae encompasses numerous live-bearing fishes and its members inhabit a wide range of environments, from tropical reefs and freshwater caves to the continental slopes and mesopelagic areas, and employ a variety of life strategies (Cohen et al., 1990). Originally described from a single individual from the Galápagos, $T$. hollisi was previously named Bythites hollisi (Cohen et al., 1990). Upon further examination of individuals of the genus Bythites, it was proposed that Bythites hollisi be designated into a new, distinct genus, Thermichthys, in reference to their habitat (Neilsen \& Cohen, 2002; Neilsen \& Cohen, 2005). Speculation regarding T. hollisi's prey preferences is scant and anecdotal within the literature (Ballard \& Grassle, 1979; Desbruyères et al., 2006). One early study suggested on the basis of behavioral observations that perhaps the fish employs a symbiosis with chemoautotrophs for nutrition, as was being recognized in multiple invertebrate species at the time (Hessler \& Smithey, 1984), while others suggested that they feed upon the microbial community (Ballard \& Grassle, 1979; Grassle, 1985). Counter to these hypotheses are additional anecdotes: whereby an observer in a submersible saw a bythitid attempt to consume what may have been a zoarcid (Desbruyères et al., 2006) and another paper claimed they are carnivorous or detritivorous (Geistdoerfer, 1998). The inclusion of a single individual from the Galápagos in a stable isotope study suggests that $T$. hollisi is positioned higher in the trophic network than a species wholly dependent upon chemoautotrophs (Fisher et al., 
1994). Fundamental questions regarding the feeding habits, trophic interactions, and impact upon vent community composition of $T$. hollisi remain unanswered, yet are integral to understanding the whole of vent community ecology.

Members of the family Bythitidae are often viviparous, and T. hollisi is no exception; live-bearing broods of up to an estimated 10,000 young (Wourms \& Moser, 1991). There is no knowledge of life-history strategy for these fish, and whether young settle at vents or migrate to them is a matter for debate. Despite numerous studies investigating larval dispersal and connectivity of invertebrates at vents (Tyler \& Young, 2003; Shank \& Halanych, 2007), this area has not been explored for vent vertebrates. Similarly, adaptation of vent vertebrates to conditions experienced within venting communities is not well defined. Geistdoerfer (1996) noted that vertebrates adapted to life at vents do not differ physically from similar non-vent species, leading to speculation that any adaptations must be at a biochemical or genetic level. To date only one study has attempted to explore T. hollisi adaptation to vent life at this level. As previously mentioned, an study of enzyme function including one $T$. hollisi individual suggests that they are less well adapted to a high temperature lifestyle (Dahlhoff et al., 1990), which may partially explain why they are typically observed in the periphery of vent fields or in enigmatic aggregations in collapse pits and cracks termed "fish holes", and not directly in active diffuse flow as is Thermarces cerberus. Yet these fish are found at venting environments and nowhere else, and what habitat conditions they are experiencing and selecting, as well as their physiological tolerances, responses, and adaptations to their 
environment remain areas of exploration in order to elucidate the role of fish within the hydrothermal vent ecosystem.

\subsection{Goals of thesis}

The ecology of vent invertebrates have been well-researched for the past thirty years, yet despite their potential ecological importance, there is little direct knowledge of the ecology and impact of fishes within hydrothermal vent ecosystems. It is the goal of this thesis to provide fundamental insights into the ecology and adaptation of ventendemic vertebrate fauna, specifically to explore the function and role of fish that are found in these environments on the East Pacific Rise, with a particular emphasis on the bythitid Thermichthys hollisi. This goal is approached from three main directions; a study of the trophic ecology of T. hollisi through stable isotope and gut content analysis to establish trophic interactions and impact on vent ecosystem structure; a study of otolith chemistry to provide the first evidence of life history strategies and habitat use in ventendemic fish; and an exploration of the characterization and expression of stressinducible genes to get a first look at vertebrate gene-level adaptation to the venting environment. 


\section{Chapter 1 References}

Anderson ME (1994) Systematics and osteology of the Zoarcidae (Teleostei: Perciformes). Ichthy Bull 60:1-116.

Arp AJ, Childress JJ (1983) Sulfide binding by the blood of the hydrothermal vent tube worm Riftia pachyptila. Science 219: 295-297.

Ballard RD, Grassle JF (1979) Return to oases of the deep. Nat Geo 156(5): 680-705.

Biscoito M, Segonzac M, Almeida AJ, Desbruyères D, Geistdoerfer P, Turnipseed M, Van Dover C (2002) Fishes from the hydrothermal vents and cold seeps - An update. Cah Biol Mar 43: 359-362.

Childress JJ, Fisher CR (1992) The biology of hydrothermal vent animals: physiology, biochemistry, and autotrophic symbiosis. Oceanogr Mar Biol A Rev 30: 337-341.

Cohen DM, Rosenblatt RH, Moser HG (1990) Biology and description of a bythitid fish from deep-sea thermal vents in the tropical eastern Pacific. Deep-Sea Res 37(2): 267-283.

Dahlhoff E, Schneidemann S, Somero GN (1990) Pressure-Temperature Interactions on $\mathrm{M}_{4}$-Lactate Dehydrogenases From Hydrothermal Vent Fishes: Evidence for Adaptation to Elevated Temperatures by the Zoarcid Thermarces andersoni, but not by the Bythitid, Bythites hollisi. Biol Bull 179: 134-139.

Desbruyères D, Segonzac M, Bright M (Editors; 2006) Handbook of Deep-Sea Hydrothermal Vent Fauna. Second completely revised edition. Denisia 18: 544pp.

Edmond JM, Measures C, McDuff RE, Chan LH, Collier R, Grant B, Gordon LI, Corliss JB (1979) Ridge crest hydrothermal activity and the balances of the major and minor elements in the ocean: The Galapagos data. Earth Plan Sci Lett 46: 1-18.

Edmond JM, Von Damm KL, McDuff RE, Measures CI (1982) Chemistry of hot springs on the East Pacific Rise and their effluent dispersal. Nature 297(5863): 187-191.

Fisher CR, Childress JJ, Macko SA, Brooks JM (1994) Nutritional interactions in Galapagos Rift hydrothermal vent communities: inferences from stable carbon and nitrogen isotope analyses. Mar Ecol Prog Ser 103: 45-55.

Geistdoerfer P (1994) Pachycara thermophilum, une nouvelle espece de poisson Zoarcide des sites hydrothermaux de la dorsale medio-Atlantiqu. Cybium 18(2): 109-115.

Geistdoerfer P (1996) L'ichthyofaune des ecosystems associés à l'hydrothermalisme océanique : état des connaissances et résultats nouveaux. Oceanologica Acta 19(5): 539-548.

Geistdoerfer P (1998) Fish fauna of chemoautotrophic marine communities. Ann Inst Oceanogr Paris 74(2): 201-215.

Geistdoerfer P, Seuront L (1995) Redescription and biology study of Thermarces cerberus (Zoarcidae) of hydrothermal vents of the East Pacific Ridge. Cybium 19(2): 167-178.

Govenar B, Le Bris N, Gollner S, Glanville J, Aperghis AB, Hourdez S, Fisher CR (2005) Epifaunal community structure associated with Riftia pachyptila in chemically different hydrothermal vent habitats. Mar Ecol Prog Ser 305: 67-77. 
Grassle JF (1985) Hydrothermal vent animals; distribution and biology. Science 229(4715): 713-717.

Haymon RM, Carbotte S, Wright D, Beedle N, Johnson F, Fornari DJ, Von Damm KL, Brebmeier J, Lilley M, McLaughlin E, Olson E, Edmond J, Perfit MR, Smith M, Shanks WC III, Lutz, R, Seewald J, Reudelhuber D (1991) Active eruption observed on the East Pacific Rise. Earth in Space 4(4): 5pp.

Haymon RM, Fornari DJ, Von Damm KL, Lilley MD, Perfit MR, Edmond JM, Shanks WC III, Lutz RA, Grebmeier JM, Carbotte S, Wright D, McLaughlin E, Smith M, Beedle N, Olson E (1993) Volcanic eruption of the mid-ocean ridge along the East Pacific Rise crest at 9 degrees $45-52$ 'N; direct submersible observations of seafloor phenomena associated with an eruption event in April, 1991. Earth Planet Sci Lett 119(1-2): 85-101.

Hessler RR \& Smithey WM (1984) The distribution and community structure of megafauna at the Galapagos Rift hydrothermal vents. In: Rona PA, Boström K, Laubier L, Smith KL (eds) Hydrothermal processes at seafloor spreading centers. NATO Conference Series IV, v.12. Plenum Press, NY pp. 735-770.

Hourdez S, Lallier FH (2007) Adaptations to hypoxia in hydrothermal-vent and cold-seep invertebrates. Rev Env Sci Bio/Tech 6(1-3): 143-159.

Jannasch HW (1979) Chemosynthetic production of biomass: an idea from a recent oceanographic discovery. Oceanus 22(4): 59-63.

Johnson KS, Childress JJ, Hessler RR, Sakamoto-Arnold CM, Beehler CL (1988) Chemical and biological interactions in the Rose Garden hydrothermal vent field, Galapagos Spreading Center. Deep-Sea Res I 35(10-11): 1723-1744.

Kelley DS, Baross JA, Delaney JR (2002) Volcanoes, Fluids, and Life at Mid-Ocean Ridge Spreading Centers. Annu Rev Earth Planet Sci 30: 385-491.

Kicklighter CE, Fisher CR, Hay ME (2004) Chemical defense of hydrothermal vent and hydrocarbon seep organisms: a preliminary assessment using shallow-water consumers. Mar Ecol Prog Ser 275: 11-19.

Lilley MD, Olson EJ (2001) Methane and Hydrogen in Active Hydrothermal Systems. Eleventh Annual V. M. Goldschmidt Conference 3682.pdf.

Lonsdale P (1977) Clustering of suspension-feeding macrobenthos near abyssal hydrothermal vent at oceanic spreading centers. Deep-Sea Res 24: 857-863.

Luther GW III, Rozan TF, Taillefert M, Nuzzio DB, Di Meo C, Shank TM, Lutz RA, Cary SC (2001) Chemical speciation drives hydrothermal vent ecology. Nature 410: 813-816.

Micheli F, Peterson CH, Mullineaux LS, Fisher CR, Mills SW, Sancho G, Johnson GA, Linihan HS (2002) Predation structures communities at deep-sea hydrothermal vents. Ecol Mono 72(3):365-382.

Neilsen JG, Cohen DM (2002) Notes on Bythites (Pisces, Bythitidae), with a new genus for B. hollisi. Arch Fish Mar Res 50(1): 49-54.

Nielsen JG, Cohen DM (1973) A review of the viviparous ophidioid fishes of the genera Bythites Reinhardt and Abythites new (Pisces, Ophidioidei). Steenstrupia 3: 71-88. 
Nielsen JG, Cohen DM (2005) Thermichthys (Bythitidae), replacement name for preoccupied Gerhardia Nielsen \& Cohen, 2002 and a second specimen of Thermichthys hollisi from the Southeast Pacific. Cybium 29(4): 395-398.

Rosenblatt RH, Cohen DM (1986) Fishes living in deepsea thermal vents in the tropical eastern Pacific, with descriptions of a new genus and two new species of eelpouts (Zoarcidae). Trans San Diego Soc Nat Hist 21(4): 71-79.

Saldanha L, Biscoito M (1997) Fishes from the Lucky Strike and Menez Gwen hydrothermal vent sites (Mid-Atlantic Ridge). Bol Mus Munic Funchal 49: 189206.

Sancho G, Fisher CR, Mills S, Micheli F, Johnson GA, Lenihan HS, Peterson CH, Mullineaux LS (2005) Selective predation by the zoarcid fish Thermarces cerberus at hydrothermal vents. Deep-Sea Res I 52:837-844.

Shank TM, Fornari DJ, Von Damm KL, Lilley MD, Haymon RM, Lutz RA (1998) Temporal and spatial patterns of biological community development at nascent deep-sea hydrothermal vents (950'N, East Pacific Rise). Deep-Sea Res II 45: 465-515.

Shank TM, Halanych KM (2007) Toward a mechanistic understanding of larval dispersal: insights from genomic fingerprinting of the deep-sea hydrothermal vent tubeworm Riftia pachyptila. Mar Ecol 28(1): 25-36.

Soule SA, Fornari DJ, Perfit MR, Rubin KH (2007) New insights into mid-ocean ridge volcanic processes from the 2005-2006 eruption of the East Pacific Rise, 9 degrees 46'N-9 degrees 56'N. Geology 35(12): 1079-1082.

Tolstoy M, Cowen JP, Baker ET, Dornari DJ, Rubin KH, Shank TM, Waldhauser F, Bohnenstiehl DR, Forsyth DW, Holmes RC, Love B, Perfit MR, Weekly RT, Soule SA, Glazer B (2006) A sea-floor spreading event captured by seismometers. Science 314(5807): 1920-1922.

Tunnicliffe V (1991) the biology of hydrothermal vents: Ecology and evolution. Oceanogr Mar Biol Annu Rev

Tyler PA, Young CM (2003) Dispersal at hydrothermal vents: a summary of recent progress. Hydrobiologia 503(1-3): 9-19.

Van Dover CL (2000) The Ecology of Deep-Sea Hydrothermal Vents. Princeton University Press, Princeton, NJ. 424pp.

Von Damm KL (1995) Controls on the Chemistry and Temporal Variability of Seafloor Hydrothermal Fluids. In: Humphris SE, Zierenberg RA, Mullineaux LS, Thomson RE (eds) Seafloor Hydrothermal Systems Physical, Chemical, Biological, and Geological Interactions. AGU pp 222-247.

Von Damm KL (2000) Chemistry of hydrothermal vent fluids from $9^{\circ}-10^{\circ} \mathrm{N}$, East Pacific Rise: "Time zero," the immediate post eruptive period. J Geophys Res 105(B5): $11203-11222$.

Von Damm KL, Oosting SE, Kozlowski R, Buttermore LG, Colodner DC, Edmonds HN, Edmond JM, Grebmeier JM (1995) Evolution of East Pacific Rise hydrothermal vent fluids following a volcanic eruption. Nature 375: 47-50.

Wourms JP, Moser HG (1991) Viviparity in the Galapagos thermal vent fish, Bythites hollisi (Ophidiiformes). Am Soc Zool. 
Zal F, Leize E, Lallier FH, Toulmond A, Van Dorsselaer A, Childress JJ (1998) SSulfohemoglobin and Disulfide Exchange: The Mechanisms of Sulfide Binding by Riftia pachyptila Hemoglobins. PNAS USA 95(15): 8897-9002. 


\title{
Chapter Two
}

\section{Trophic Ecology of the Hydrothermal Vent Fish Thermichthys hollisi}

\begin{abstract}
Dietary preferences and trophic interactions of the vent fish Thermichthys hollisi were explored using a combination of gut content and stable isotope analyses. Gut contents indicated that $T$. hollisi specimens were actively feeding upon a combination of brachyuran crabs, Alvinocaris shrimp, polychaetes, and zoarcid fish with the majority of fish containing evidence of various crustacean prey. Carbon, nitrogen, and sulfur stable isotopic measurements of $T$. hollisi tissues and potential prey items support a chemosynthetically based prey source and place T. hollisi in the uppermost trophic levels of vent communities. Liver and muscle tissue exhibited significantly different carbon and sulfur isotopic values, which may be indicative of a dietary shift. The implications of $T$. hollisi predation upon vent community composition and structure are discussed.
\end{abstract}

\subsection{Introduction}

Energy transfer through an ecosystem as a result of trophic interactions and dynamics is a ubiquitous factor affecting the function of all marine systems. At midocean ridge venting ecosystems, the flow of energy through the biological system is inherently linked to geological and chemical processes, ultimately generated from energy and material from the mantle of the earth itself. Marine ecologists have made it a fundamental goal to understand this flow of energy through ecosystems, and in the case of mid-ocean ridge ecosystems, understanding the complex linkages between planetary processes and biological communities is a goal of national research programs such as Ridge 2000 (www.ridge2000.org). Microbial - invertebrate trophic linkages at midocean ridges have been investigated for thirty years, forming the basis for energetic models that are currently being refined. A fundamental question still remaining is how the energy and mass at these lower levels is transferred to higher-level consumers (e.g. 
predatory fish) and the surrounding deep-sea and how these interactions affect the community as a whole.

The influence of species interactions on ecosystem structure and/or function has been documented in numerous environments, ranging from temperate coastal (Bologna, 2007) to tropical (Carpenter, 1988) to polar areas (Barrett \& Krasnov, 1996). More specifically, the ability of predators to both directly and indirectly influence the composition and structure of ecosystems has long been acknowledged (the concept of tropho-dynamics in Lindeman, 1942). The classic study of sea otter predation on urchin populations within Pacific kelp forests (Estes et al., 1978) illustrates how the actions of a single predator can impact an entire ecosystem.

In numerous aquatic ecosystems, fish often occupy high trophic levels. Many economically important fish species play a role in the structuring of ecosystems, making an understanding of their role in trophic and ecosystem dynamics and energy transfer valuable for both conservation and management decisions. Diverse habitats such as coral reefs, seamounts, estuaries, and deep-sea environments all contain examples of how predatory fish both directly and indirectly influence their environment (Table 2.1). Not only the presence of predators, but the density and diversity of predatory species may affect the rest of the ecosystem (Guidetti, 2007). The collapse of the North Atlantic cod fishery lead directly to an increase in shrimp and snow crab, and a shift from demersal to pelagic fish species (Savenkoff et al., 2007; Worm \& Myers, 2003; Bundy, 2005). This shift in dominant species has been implicated as the driving force behind changes in species composition and abundance of sediment fauna (Quijon \& Snelgrove, 2005), 
providing another example of how predation can play a major, though perhaps indirect, role in shaping the surrounding ecosystem.

Table 2.1 Examples of direct and indirect effects of fish predation.

\begin{tabular}{|l|l|l|l|l|}
\hline Fish species & habitat & directly affects & indirectly affects & study \\
\hline $\begin{array}{l}\text { Cynocion regulus \& } \\
\text { Paralichthys dentatus }\end{array}$ & $\begin{array}{l}\text { eelgrass } \\
\text { beds }\end{array}$ & $\begin{array}{l}\text { shrimp, crabs and } \\
\text { smaller fish }\end{array}$ & benthic species & Bologna, 2007 \\
\hline kelp perch \& señorita & kelp forest & mesograzers & $\begin{array}{l}\text { kelp } \\
\text { invertebrate } \\
\text { recruitment }\end{array}$ & $\begin{array}{l}\text { Davenport \& } \\
\text { Anderson, } \\
2007\end{array}$ \\
\hline Salvelinus fontinalis & $\begin{array}{l}\text { boreal } \\
\text { stream }\end{array}$ & invertebrates & algae & $\begin{array}{l}\text { Bechara et al., } \\
\text { 2007 }\end{array}$ \\
\hline $\begin{array}{l}\text { Paralichthys albigutta } \\
\text { \& spot }\end{array}$ & estuary & & $\begin{array}{l}\text { Terrebillid } \\
\text { polychaetes }\end{array}$ & $\begin{array}{l}\text { Gloeckner \& } \\
\text { Luczkovich, } \\
\text { 2008 }\end{array}$ \\
\hline $\begin{array}{l}\text { foraging herbivores } \\
\text { (e.g. acanthurids) }\end{array}$ & coral reef & macroalgae & coral & $\begin{array}{l}\text { Ceccarelli et } \\
\text { al., 2005 }\end{array}$ \\
\hline seabream \& wrasse & $\begin{array}{l}\text { rocky } \\
\text { sublittoral }\end{array}$ & sea urchins & & Guidetti, 2007 \\
\hline
\end{tabular}

\subsubsection{Fish at Hydrothermal Vents}

Despite evidence that organisms such as fish may play a significant role in structuring community composition through predation, higher trophic level interactions have not been extensively explored in deep-sea systems, and in particular, in chemosynthetic vent environments known to support high biomass (but see Sancho et al., 2005; Micheli et al., 2002; MacAvoy et al., 2002). Ecological studies on the East Pacific Rise (EPR) have typically focused on understanding bottom-up controls of community structure through fluid chemistry (Shank et al., 1998; Luther et al., 2001) and species colonization (Mullineaux et al., 2000), with less attention paid to top-down regulation through predation. Yet predation has been hypothesized to play a structural role in these 
communities as well. On the EPR, there are two species of vent-endemic fish: the zoarcid Thermarces cerberus, and the bythitid Thermichthys hollisi. T. cerberus is typically found in close association with diffuse fluid flow, among individuals of the vestimentiferan tubeworm Riftia pachyptila, or the mussel Bathymodiolus thermophilus. In contrast, $T$. hollisi is often observed on the periphery of vent fields and in enigmatic aggregations referred to as "fish holes" with no visible fluid flow or associated fauna (Figure 2.1). The effects of $T$. cerberus predation on the surrounding community are evident within the epifaunal communities nearest to active vents. When T. cerberus was excluded, the invertebrate species that showed the greatest increases were those most often preyed upon by the zoarcid, including the gastropods Cyathermia naticoides and Lepetodrilus elevatus, and the amphipod Ventiella sulfuris (Micheli et al., 2002). T. cerberus may have effects on community structure through feeding habits that are selective for both species and size (Sancho et al., 2005), with preference shown for the larger limpets. It has been hypothesized that T. cerberus exhibits control over invertebrate settlement and recruitment though its selective predation.

Thermichthys hollisi, which lives in a slightly different micro-environment than the Thermarces cerberus may exhibit a similar structural impact upon its prey species. Currently, there is an absence of basic ecological knowledge of this species, including the identity of preferred prey species. There are no direct studies of T. hollisi feeding preferences, yet they are referenced as being carnivorous or detrivorous (Geistdoerfer, 1998) with anecdotal evidence that they may feed upon other fish (Desbruyères et al., 2006). 
This study specifically aims to investigate the feeding ecology of Thermichthys hollisi and to better understand what potential role this species may play in structuring vent community dynamics. Gut content analyses and stable isotope measurements were employed in order to accomplish these aims. 


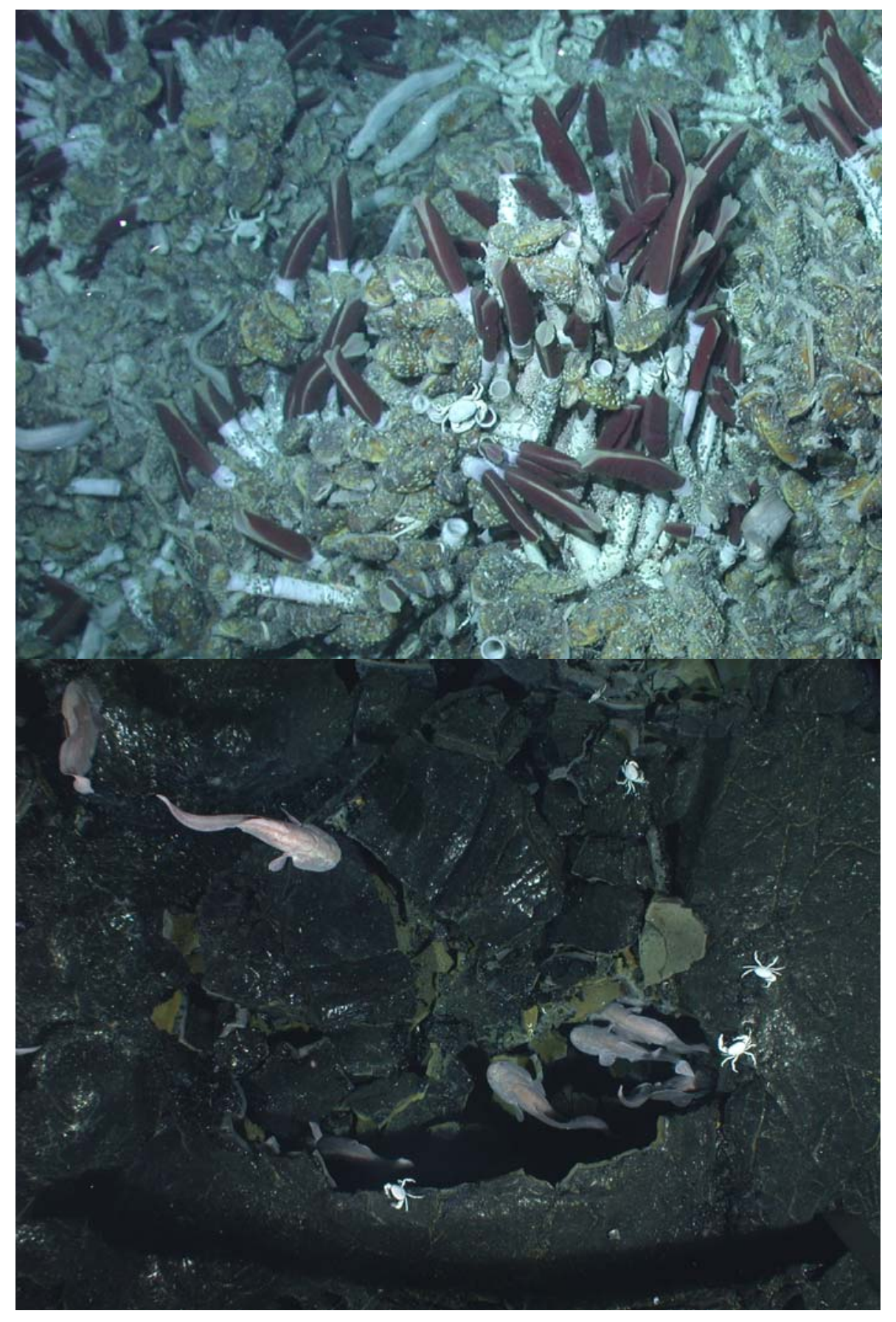

Figure 2.1 Thermarces cerberus and Thermichthys hollisi in their typical habitat. The zoarcid (upper panel) is commonly associated with tubeworm communities in diffuse flow areas while the bythitid (lower panel) is more often seen in the periphery or in collapse pits. 


\subsubsection{Gut Content and Stable Isotope Dynamics}

Gut content analyses have historically been a relatively simple way to determine the diet of fish. However, there are some caveats that warrant consideration. Opportunistic or sit-and-wait predators, including many deep-sea fish, do not feed regularly. When examining fish that employ such a feeding strategy, the probability of finding an empty gut is high. Herbivorous fish and some benthic feeders consume items that are difficult to identify before they are consumed and particularly difficult after they have been chewed and swallowed (Hadwen et al., 2007). Despite these potential pitfalls, gut content analyses remain an important component in determining the feeding ecology of fishes. When used in combination with stable isotope analyses, feeding habits (both long and short term), and their potential affect upon the surrounding community may be established.

Stable isotopes have been utilized for many years in ecological research (DeNiro \& Epstein, 1978; Peterson \& Fry, 1987; Hobson, 1999). The relative predictability of fractionation effects, consistent cross-species and cross-environment behaviors and trends of stable isotopes have made them useful in determining trophic relationships, tracking migrations (Clark et al., 2006), identifying feeding grounds, and quantifying dietary contributions (McConnaughey and McRoy, 1979) across many taxa in both terrestrial and aquatic environments (reviewed in Gannes et al., 1998 and Hobson, 1999). In trophic studies, carbon and nitrogen are the most commonly utilized elements, but sulfur isotopes have also proven useful in clarifying trophic relationships and contributions, especially in 
reducing environments such as marsh sediments or hydrothermal vents (Yamanaka et al., 2003; MacAvoy et al., 2005).

The ratio of ${ }^{13} \mathrm{C}$ to ${ }^{12} \mathrm{C}$ is established during carbon fixation by primary producers such as plants, algae, and microbial organisms. Different carbon fixation pathways result in different ratios, and these unique signatures are transferred relatively unchanged $(\sim 1 \%$ per trophic level) throughout the trophic network. $\delta^{13} \mathrm{C}$ (the ratio of ${ }^{13} \mathrm{C}$ to ${ }^{12} \mathrm{C}$ in a sample relative to that in a standard) can therefore be useful in establishing the base of a food web. Higher level predators such as fish can exhibit intermediate values which may indicate the utilization of multiple carbon sources. For example, Winemiller et al. (2007) were able to distinguish primary production sources ( $\mathrm{C} 4$ plants, $\mathrm{C} 3$ plants, etc.) using carbon isotopes, but were unable to fully resolve which were consumed by marsh invertebrates and fish due to overlapping signatures.

Nitrogen isotopes have been shown to fractionate more substantially during trophic interactions. Light isotopes are preferentially utilized, leading to approximately 3-5\% enrichment in whole body samples per trophic level (Minigawa \& Wada, 1984). Nitrogen tracks proteins well and is often used to indicate potential trophic level. Tissue analyzed, turnover rate, and amino acid composition, and lipid content can each affect the measured isotope ratios and the fractionation rates, and must therefore be considered when analyzing data.

Multiple species of sulfur are found in the marine environment, the most common and biologically relevant in the open ocean being sulfate. Average seawater sulfate has an isotopic value of approximately 21\%o (Rees et al., 1978). Phytoplankton take up and 
utilize sulfate resulting in a 0 to $-3 \%$ fractionation. This signature is retained throughout successive trophic levels with no appreciable trophic fractionation (Fry et al., 1983). Due to the homogenous nature of sulfur signatures in the open ocean, $\delta^{34} \mathrm{~S}$ is of limited use in ecological studies of strictly pelagic species. However, in environments such as nearcoastal, estuarine areas or reducing environments such as vents of tidal mud flats, sulfur isotopes have proven useful. The lack of trophic fractionation makes sulfur particularly useful for understanding trophic and feeding dynamics of fauna, and through them, migratory dynamics in environments with variable sulfur signature inputs (MacAvoy et al., 1998).

For all elements, the rate of turnover may have an effect on which target tissues are most useful. MacAvoy et al. (2001) and Tarboush et al. (2006) have found that sulfur turnover in tissues may be slow enough to underestimate dietary shifts, especially if prey species are migratory. In appropriate habitats, where sulfur water signatures vary, sulfur isotopes, in combination with other stable isotopes can be a powerful tool to study trophic influence and through these results, a means to learn about ecological processes such as migration, life history strategies, and nutritional dependence.

\subsubsection{Stable Isotope Studies at Hydrothermal Vents}

Stable isotope studies have been conducted in hydrothermal vent and cold-seep environments since shortly after their discovery (Rau \& Hedges, 1979). These studies have been conducted across ocean basins in dissimilar locations including the Louisiana slope (Brooks et al., 1987), the Galápagos (Fisher et al., 1994), the Juan de Fuca ridge 
(Bergquist et al., 2007), the Mid-Atlantic Ridge (Colaco et al., 2002), the Indian Ocean (Van Dover, 2002) the Japan subduction zone (Saino \& Ohta, 1989), and the East Pacific Rise (Van Dover \& Fry, 1994). General trends found across most of these locales indicate that many vent systems host similar biogeochemical processes (Van Dover \& Fry, 1994). The above studies were able to verify the presence of local sources of carbon and nitrogen at the vents, showing that vent organisms are not dependent upon surface primary production (Rau, 1981; Williams et al., 1981; Van Dover \& Fry, 1989). Chemoautotrophic microbes, the primary producers at vents, discriminate against ${ }^{13} \mathrm{C}$ (Fisher et al., 1990), thus organisms harboring chemoautotrophic symbionts, such as the tubeworm Riftia pachyptila or the mussel Bathymodiolus thermophilus, tend to have depleted carbon signatures relative to "typical" or non-chemosynthetic deep-sea fauna. Typical non-vent deep-sea invertebrate stable isotope values have been reported as ranging from -22 to $-17 \%$ for carbon and 11 to $16 \%$ for nitrogen (Brooks et al., 1987; Van Dover \& Fry, 1989). Though non-symbiont-containing vent invertebrates display a large range in carbon isotope values that at times include those of non-vent fauna (Van Dover \& Fry, 1989, Fisher et al., 1994), nitrogen values are generally depleted relative to non-vent fauna (Van Dover \& Fry, 1989; Van Dover \& Fry, 1994). Fisher et al. (1994) hypothesize that vent invertebrates all have a nitrogen value of less than $11 \%$, making nitrogen a good indicator of vent dependent fauna.

Sulfur isotopes have also been shown to be useful in indicating which species are dependent upon vent "produced" nutrition (MacAvoy et al., 2005). Hydrothermal fluids are in general depleted relative to seawater, with values ranging from -3 to $8 \%$ (Shanks et 
al., 1995). Vent endemic fauna mirror these values and seem to center around 0\%o (Mizota, 1997). Organisms with thiotrophic symbioses generally have tissue sulfur values less than 5\%, indicating their dependence upon the symbiosis, and thus in turn, the depleted sulfide available in the environment (Vetter and Fry, 1998). Dependence upon the primary production of chemosynthesis versus photosynthesis can also be reflected in tissues of scavengers and predators. Carbon, nitrogen, and sulfur tissue isotopic values of fish and invertebrates living near a hydrocarbon seep in the Gulf of Mexico indicated chemosynthetic input and trophic export from the seeps (MacAvoy et al., 2002).

The combination of gut content analyses and stable isotope measurements will allow for an exploration of the dietary preferences and trophic relationships of the vent fish Thermichthys hollisi. As presumed top predators, these fish have the potential to significantly affect community structure and composition, making the ecology of $T$. hollisi of importance to understanding hydrothermal vent community ecology and the transfer of energy through this community and to the surrounding deep-sea.

\subsection{Methods}

\subsubsection{Specimen collection and sample sites}

Thermichthys hollisi specimens were collected using a thruster powered suction sampler designed by The Deep Submergence Lab at WHOI (Figure 2.2). The sampler consisted of an initial collection chamber attached to a spare thruster with a unidirectional door on the opposite end of the chamber. This door opened into a second chamber where 
collected fish were stored for transport to the surface. A large flexible tube ran from the initial collection chamber, ending in a funnel-shaped attachment with a T-handle for the Alvin manipulators to grasp. The thruster was run in one direction to slurp fish through the tube into the initial chamber, and then the direction reversed to push the fish through the door into the final chamber to prevent damaging them during the subsequent collection of additional fish.

The sampler was mounted on the basket of the submersible DSV Alvin during dive 4317 at $\mathrm{L}$ vent $\left(9^{\circ} 46.256 \mathrm{~N}, 104^{\circ} 16.776 \mathrm{~W}\right)$ on the East Pacific Rise (Figure 2.3). Fish were collected from multiple collapse pits ("fish holes") surrounding the main hydrothermal chimney at the site by approaching a fish hole, stabilizing the submarine, inserting the sampler into the fish hole and turning it on. The fish did not seem to react to the presence of the sub until they were physically touched with the sampler. In total 26 Thermichthys hollisi individuals were collected from L vent. Multiple tissue type samples were dissected from each individual and frozen separately. One individual was collected from L vent using a net during dive 4293 and frozen whole. The digestive tract of this individual was subsequently dissected out and examined while still frozen. Invertebrate and Thermarces cerberus specimens used in this study were collected from various locations on the EPR (Table 2.2) during multiple cruises in order to account for the range of prey fish may be encountering. Invertebrates were collected using Alvin manipulator grab samples and slurp samples and placed in a biobox for recovery. These specimens were sorted, identified and frozen at $-80^{\circ} \mathrm{C}$ while at sea. 


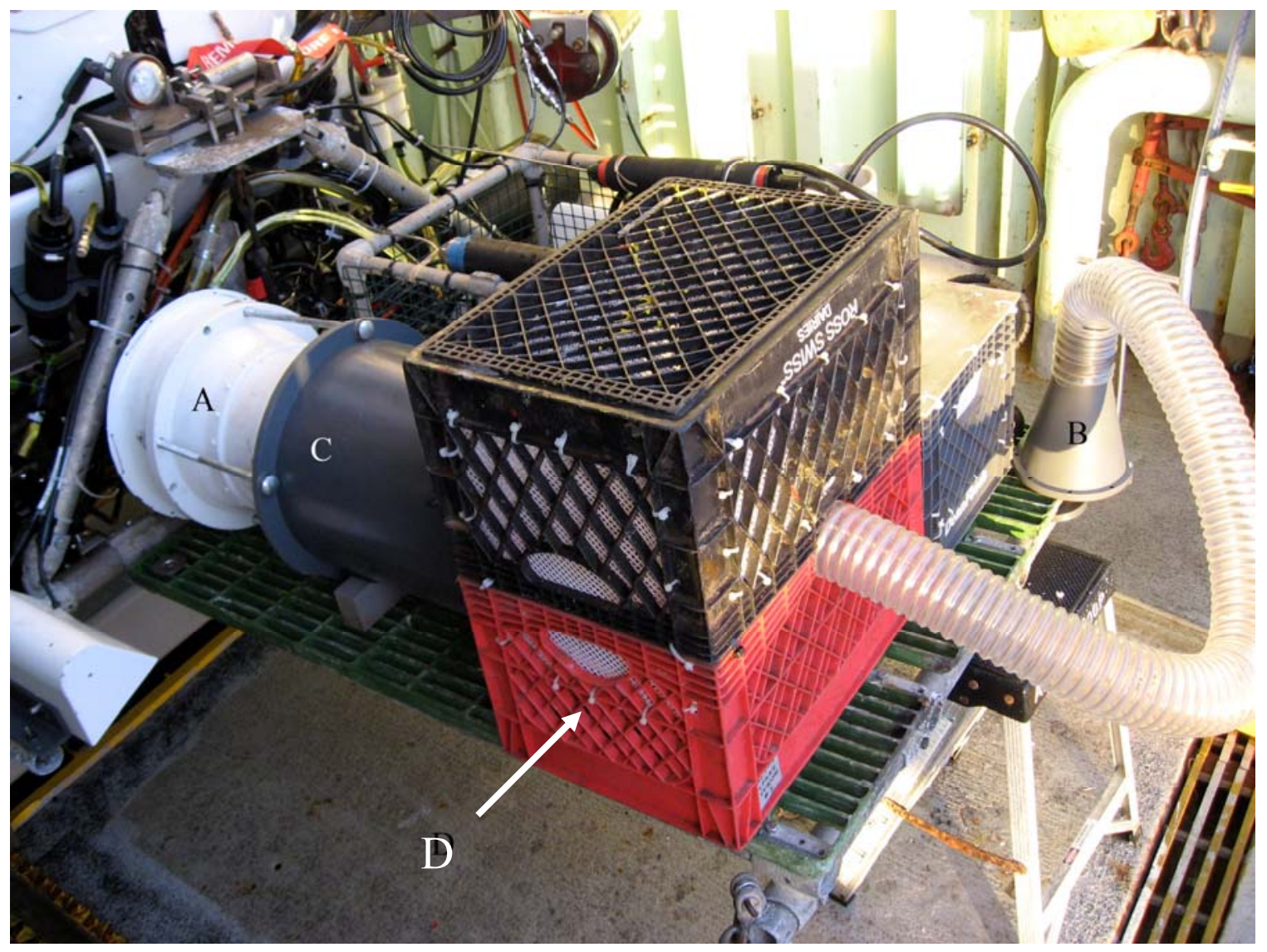

Figure 2.2 The "super-sucker" mounted on the Alvin basket for deployment. A. reversible direction Alvin thruster B. nozzle with T-handle for ease of slurping C. initial collection chamber with trap door into D. final collection and recovery chamber 


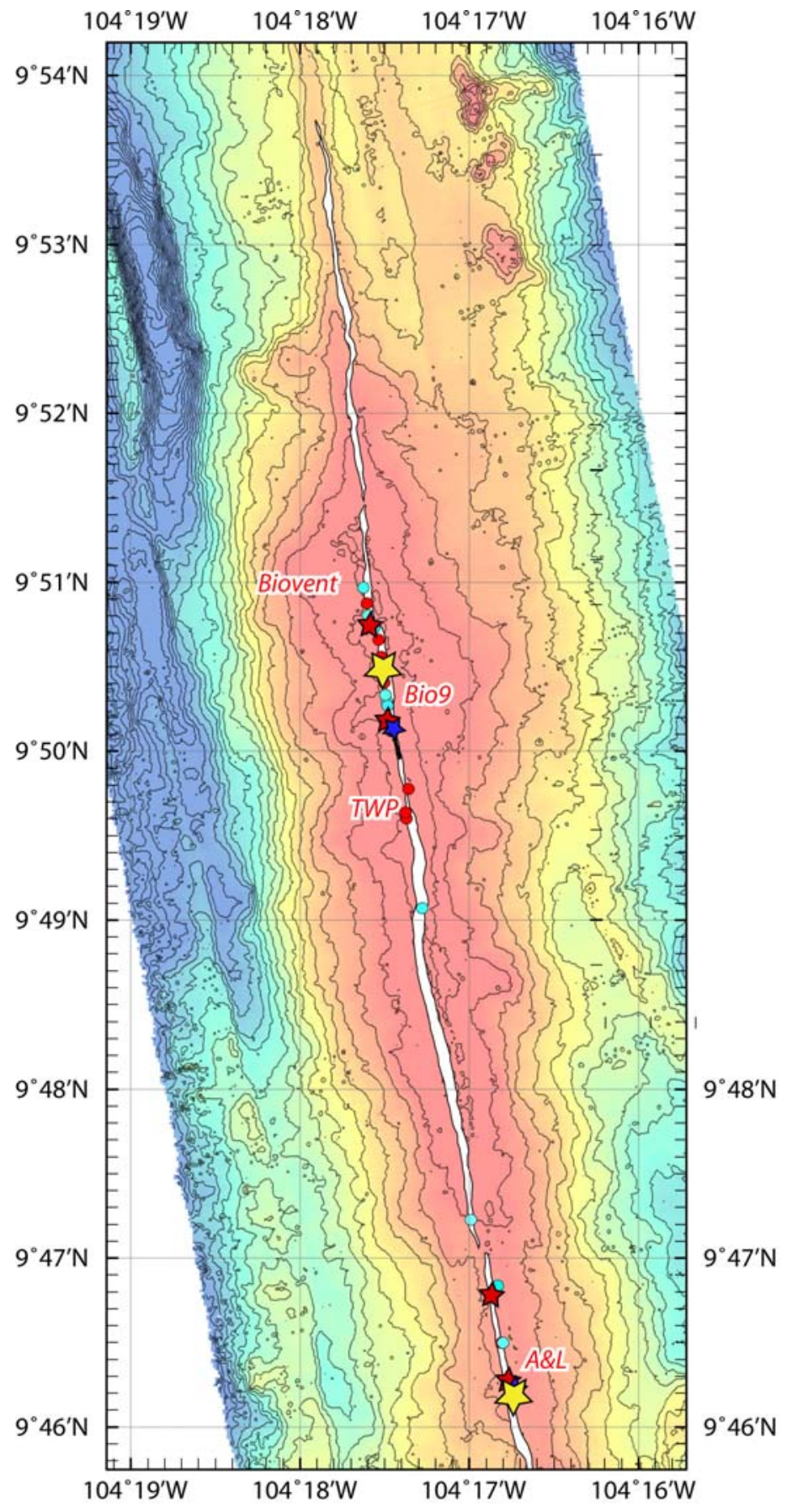

sampling locations for

- pre-eruption vents

- $\quad$ suspected post-eruption active

$\checkmark$ known post-eruption

high-temperature

$\checkmark$ known post-eruption

low-temperature vent

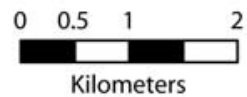

Figure $2.39^{\circ} \mathrm{N}$ segment of the East Pacific Rise with major sampling locations marked by yellow stars. 
Table 2.2 Mean isotopic values and locations collected for all species examined.

\begin{tabular}{|c|c|c|c|c|c|}
\hline Species & $\begin{array}{l}\text { locations } \\
\text { collected }\end{array}$ & $\begin{array}{l}\mathrm{n} \text { of } \mathrm{C} / \mathrm{N} \\
\text { samples (n } \\
\text { of sulfur) }\end{array}$ & $\begin{array}{l}\text { mean } \delta^{13} \mathrm{C} \\
\% \text { (st. dev.) }\end{array}$ & $\begin{array}{l}\text { mean } \delta^{15} \mathrm{~N} \% o \\
\text { (st. dev.) }\end{array}$ & $\begin{array}{l}\text { mean } \delta^{34} \mathrm{~S} \% \mathrm{o} \\
\text { (st. dev.) }\end{array}$ \\
\hline Alvinocaris lusca & L vent & $2(1)$ & $-16.42(0.07)$ & $10.68(0.64)$ & 4.94 \\
\hline Alvinella pompejana & $\begin{array}{l}\text { L vent, } \\
\text { Alvinella } \\
\text { Pillar }\end{array}$ & $13(3)$ & $-10.14(1.06)$ & $6.11 \quad(0.62)$ & $8.57 \quad(2.14)$ \\
\hline $\begin{array}{l}\text { Branchinotogluma } \\
\text { grasslei }\end{array}$ & Tica & $3(1)$ & $-11.95(1.09)$ & $8.05(0.3)$ & 1.83 \\
\hline $\begin{array}{l}\text { Branchinotogluma } \\
\text { hessleri }\end{array}$ & L vent & 3 & $-9.71(1.15)$ & $8.44(0.59)$ & \\
\hline $\begin{array}{l}\text { Bythograea } \\
\text { thermydron }\end{array}$ & East Wall & $3(3)$ & $-14.91(1.00)$ & $6.95(0.31)$ & $-2.37(0.81)$ \\
\hline Cyanograea praedator & L vent & 1 & -9.15 & 7.99 & \\
\hline copepod & L vent & 1 & -11.78 & 8.02 & \\
\hline Cyathermia naticoides & East Wall & $2(1)$ & $-6.00(5.59)$ & $6.42(0.98)$ & \\
\hline Dahlella calderiensis & L vent & $2(2)$ & $-11.43(1.99)$ & $7.67(0.26)$ & $6.17(0.50)$ \\
\hline Eulepotopsis vitrea & Tica & $5(1)$ & $-15.37(1.52)$ & $7.96(0.88)$ & 4.5 \\
\hline $\begin{array}{l}\text { Munidopsis } \\
\text { subsquamosa }\end{array}$ & East Wall & 1 & -19.57 & 12.63 & \\
\hline Hesiolyra bergi & $\begin{array}{l}\text { East Wall, L } \\
\text { vent, A/L }\end{array}$ & $5(2)$ & $-10.7(0.98)$ & $7.09(1.02)$ & $5.44(1.37)$ \\
\hline Lepetodrilus elevatus & $\begin{array}{l}\text { Alvinella } \\
\text { Pillar, BM } \\
\text { 119, East } \\
\text { Wall, L vent, } \\
\text { Tica }\end{array}$ & $10(1)$ & $-15.34(2.74)$ & $5.89(2.31)$ & 2.07 \\
\hline Lepetrodrilus ovalis & BM 119 & 2 & $-19.47(0.79)$ & $7.42(0.12)$ & \\
\hline $\begin{array}{l}\text { Lepetodrilus } \\
\text { pustulosus }\end{array}$ & $\begin{array}{l}\text { BM 119, L } \\
\text { vent }\end{array}$ & 5 & $-15.49(1.73)$ & $7.93(1.02)$ & \\
\hline $\begin{array}{l}\text { Lepidonotopodium } \\
\text { fimbriatum }\end{array}$ & BM 119 & 1 & -11.48 & 10.00 & \\
\hline $\begin{array}{l}\text { Lepidonotopodium } \\
\text { williamsae }\end{array}$ & BM 119 & $3(2)$ & $-31.64(0.13)$ & $4.17(0.32)$ & $3.65(0.32)$ \\
\hline Nereis sandersi & L vent, Tica & $6(3)$ & $-12.14(0.81)$ & $8.45(1.19)$ & $5.7(1.12)$ \\
\hline Oasisia alvinae & East Wall & 2 & $-11.49(1.48)$ & $8.70(0.57)$ & \\
\hline Paralvinella grasslei & East Wall & $4(2)$ & $-10.64(1.23)$ & $9.53(0.84)$ & $6.24(0.80)$ \\
\hline $\begin{array}{l}\text { Rhynchopelta } \\
\text { concentrica }\end{array}$ & $\begin{array}{l}\text { BM 119, East } \\
\text { Wall, Tica }\end{array}$ & 11 & $-12.84(2.00)$ & $6.03(0.88)$ & \\
\hline Riftia pachyptila & $\begin{array}{l}\text { Alvinella } \\
\text { Pillar, East } \\
\text { Wall, L vent }\end{array}$ & 8 & $-12.17(1.69)$ & $3.09(0.48)$ & \\
\hline Tevnia jerichonana & $\begin{array}{l}\text { BM 119, L } \\
\text { vent }\end{array}$ & $10(4)$ & $-9.88(0.76)$ & $3.10(1.49)$ & $-2.32(0.64)$ \\
\hline $\begin{array}{l}\text { Thermarces cerberus } \\
\text { (liver) }\end{array}$ & East Wall & $1(1)$ & -10.42 & 11.91 & 2.62 \\
\hline $\begin{array}{l}\text { Thermarces cerberus } \\
\text { (muscle) }\end{array}$ & East Wall & $2(2)$ & $-9.7(0.42)$ & $11.62(1.63)$ & $2.11(1.15)$ \\
\hline Thermichthys hollisi & L vent & $15(15)$ & $-10.72(0.80)$ & $12.09(0.97)$ & $2.85(2.57)$ \\
\hline
\end{tabular}




\begin{tabular}{|l|l|l|l|l|l|}
\hline (liver) & & & & & \\
\hline $\begin{array}{l}\text { Thermichthys hollisi } \\
\text { (muscle) }\end{array}$ & L vent & $14(15)$ & $-14.69(1.26)$ & $11.68(0.84)$ & $0.80(1.18)$ \\
\hline Ventiella sulfuris & $\begin{array}{l}\text { East Wall, L } \\
\text { vent }\end{array}$ & $9(2)$ & $-14.19(4.73)$ & $6.54(1.74)$ & $9.15(2.28)$ \\
\hline
\end{tabular}

\subsubsection{Gut Content Analysis}

Digestive systems (stomach and intestines) were excised from the dead fish and preserved whole in $95 \% \mathrm{EtOH}$ while at sea. Recovery from the seafloor caused some of the fish to lose stomach contents, however, any easily distinguishable prey items that were remaining in the mouth or protruding from the stomach were noted, removed, and frozen whole. Upon return to the shore-based lab the digestive tracts of 23 individuals were dissected and the contents scraped out into a Petri dish. Contents were examined underneath a dissecting microscope (Leica MZ APO), identified to the lowest possible taxonomic level, and photographed. The individual gut contents were subsequently preserved separately from the digestive tract remains in $70 \% \mathrm{EtOH}$.

Molecular methods were used to secondarily identify selected gut contents. DNA was extracted from the frozen stomach contents using a Qiagen DNEasy extraction kit according to the manufacturer's instructions. Usable DNA was not recoverable from the preserved contents. The DNA was amplified using degenerate primers (dgLCO1490 and dgHCO2198 Meyer et al., 2005) for the cytochrome oxidase I gene by combining $1 \mu 1$ DNA template, $5 \mu 15 \mathrm{x}$ buffer (Promega Flexi), $5 \mu 125 \mathrm{mM}$ magnesium chloride, $2.5 \mu 1$ $1 \mathrm{mM}$ dNTPs, $1.25 \mu \mathrm{l}$ of both forward and reverse primers (10 $\mu \mathrm{M}$ concentration), and $0.25 \mu 1$ of Promega Flexi Taq polymerase $(5 \mathrm{u} / \mu \mathrm{l})$ in a $25 \mu 1$ reaction. The PCR reaction was run for 3 minutes at $94^{\circ}$ followed by either 30 cycles of 1 minute at $94^{\circ}, 1$ minute at 
$47^{\circ}, 45$ seconds at $72^{\circ}$, or 39 cycles of 1 minute at $94^{\circ}, 1$ minute at $45^{\circ}, 45$ seconds at $72^{\circ}$, with a final extension period of 7 minutes at $72^{\circ}$. PCR products were visualized on an agarose gel stained with ethidium bromide and cleaned up using a Qiagen kit according to the manufacturer's instructions. Amplified fragments were sequenced on an Applied Biosystems 3730XL capillary sequencer at the Josephine Bay Paul Center (Marine Biological Laboratory, Woods Hole, MA). The resulting fragments were analyzed using standard genetic software and compared to sequences in GenBank or sequences from known specimens within the lab.

\subsubsection{Stable Isotope Analysis}

Tissue samples from both fish and invertebrate samples (muscle, liver, and whole organism) were dried for a minimum of 48 hours at $60^{\circ} \mathrm{C}$ in a Fisher Scientific drying oven. Whenever possible muscle tissue was utilized for invertebrate specimens, however for smaller species such as amphipods and limpets whole individuals were analyzed. Individuals were pooled when necessary to ensure sufficient tissue for analysis. Fish tissue samples that did not initially appear dry after 48 hours were left in the oven for a

minimum of 96 hours to ensure complete desiccation. Samples were analyzed for natural abundance, they were not acid treated, lipid-extracted or otherwise pre-treated. Once dried, the samples were ground to a fine powder using a mortar and pestle and weighed into tin capsules $(0.6-1.2 \mathrm{mg}$ for $\mathrm{C} / \mathrm{N}$ analysis, $5.8-6.2 \mathrm{mg}$ for $\mathrm{S}$ analysis). Samples were analyzed at the Colorado Plateau Stable Isotope Laboratory (Flagstaff, AZ) using a Costech ECS 4010 elemental analyzer interfaced to a Delta Plus Advantage mass 
spectrometer. Percent $\mathrm{C} / \mathrm{N}$ or $\mathrm{S}$ content as well as delta ratios were reported. Data are presented in standard $\delta$ notation relative to a standard. For example $\delta^{13} \mathrm{C}=$ $\left[\left(\mathrm{R}_{\text {sample }} / \mathrm{R}_{\text {standard }}\right)-1\right] * 10^{3}$ where $\mathrm{R}={ }^{13} \mathrm{C} /{ }^{12} \mathrm{C}$. Standards used were Vienna Pee Dee Belemnite for carbon, air for nitrogen and Canyon Diablo Troilite for sulfur.

Fish tissues were lipid normalized according to Kiljunnen's (2006) method. A simple two-source mixing equation (as in MacAvoy et al., 2002) was employed to estimate potential vent/non-vent dietary input. Input was estimated by the equation: $\delta^{\mathrm{x}} \mathrm{E}_{\text {predator }}-\mathrm{F}=\left(\delta^{\mathrm{x}} \mathrm{E}_{\mathrm{vent}} * \mathrm{f}_{\mathrm{vent}}\right)+\left(\delta^{\mathrm{x}} \mathrm{E}_{\text {ocean }} *\left(1-\mathrm{f}_{\mathrm{vent}}\right)\right)$ where $\delta^{\mathrm{x}} \mathrm{E}$ is the mean isotopic signature for the element (E) in question, $\mathrm{F}$ is a term to correct for trophic enrichment, and $\mathrm{f}$ is the fraction of diet made up by a chemoautotrophic source. F for carbon, nitrogen and sulfur was 1,3 , and $0 \%$ respectively. $\delta^{\mathrm{x}} \mathrm{E}_{\text {ocean }}$ was represented by mean non-vent fauna measurements of $-18.5 \%$ and $13.5 \%$ for carbon and nitrogen respectively (Van Dover and Fry, 1989), and 18\%o for sulfur (Mizota, 1997). $\delta^{\mathrm{x}} \mathrm{E}_{\text {predator }}$ represented mean T. hollisi values measured in this study and $\delta^{\mathrm{x}} \mathrm{E}_{\mathrm{vent}}$ was calculated from mean vent invertebrates values in this study. Analyses were carried out for each isotope separately for muscle and liver tissue values. In order to assess potential dietary contribution with greater resolution, average measured values for major taxonomic categories (crustacean, polychaete, vestimentiferan, limpet, non-vent, and zoarcid) were submitted as potential food sources to the program Isosource (Phillips \& Gregg, 2003). 1\% increments and a 0.1 tolerance were utilized. 


\subsection{Results}

\subsubsection{Gut Content Analyses}

Of the 23 fish analyzed, only three of them contained prey items within their upper digestive tract, while all individuals examined contained evidence of prey items within the intestinal portion of the digestive tract. The identifiable prey items fell into four broad taxonomic groups: crustaceans, polychaetes, mollusks, and fish; with the highest percentage of Themichthys hollisi individuals containing crustacean remains, followed by polychaetes (Table 2.3). Evidence of polychaete consumption was visible only by the presence of chaetae within the intestinal tract (Figure 2.4). Unfortunately, it was not possible to identify the preserved remains to a lower taxonomic level using molecular techniques. Crustacean remains within the lower intestinal tract were mainly portions of exoskeleton (Figure 2.5). Using molecular techniques, crustacean prey within the stomachs were identified as Alvinocaris lusca and brachyuran crabs. Two individuals were found to have consumed Thermarces cerberus (Figure 2.6), the other vent fish species frequently observed at East Pacific Rise venting localities. 
Table 2.3 Proportion of Thermicthys hollisi individuals containing a particular prey type within the digestive tract. Though the ascent to the surface apparently caused a few of the fish to partially empty their stomachs, four of the 23 fish analyzed had prey in their stomach or mouth, and all individuals had evidence of prey in their lower intestines. One lower intestine was not examined because it was lost during transport back to the lab. Additional specimens of both Alvinocaris lusca and Thermarces cerberus were found in the collection basket, but could not be associated with a specific $T$. hollisi individual.

\begin{tabular}{|l|l|l|l|}
\hline & prey & $\begin{array}{l}\text { present in stomach } \\
(\mathrm{n}=23)\end{array}$ & $\begin{array}{l}\text { present in intestines } \\
(\mathrm{n}=22)\end{array}$ \\
\hline $\begin{array}{l}\text { percent of fish } \\
\text { processed with } \\
\text { particular prey item } \\
\text { present }\end{array}$ & crab - brachyuran & 4.3 & 0 \\
\cline { 2 - 4 } & $\begin{array}{l}\text { shrimp - } \\
\text { Alvinocaris lusca }\end{array}$ & 8.6 & 0 \\
\cline { 2 - 4 } & unid. crustacean & 0 & 40.3 \\
\cline { 2 - 4 } & $\begin{array}{l}\text { fish - Thermarces } \\
\text { cerberus }\end{array}$ & 8.6 & 0 \\
\cline { 2 - 4 } & polychaete & 0 & 36.4 \\
\cline { 2 - 4 } & non-biological & 0 & 13.6 \\
\cline { 2 - 4 } & $\begin{array}{l}\text { mollusk - unid } \\
\text { limpet }\end{array}$ & 0 & 4.5 \\
\cline { 2 - 4 } & unidentifiable & 4.3 & 100 \\
\hline
\end{tabular}




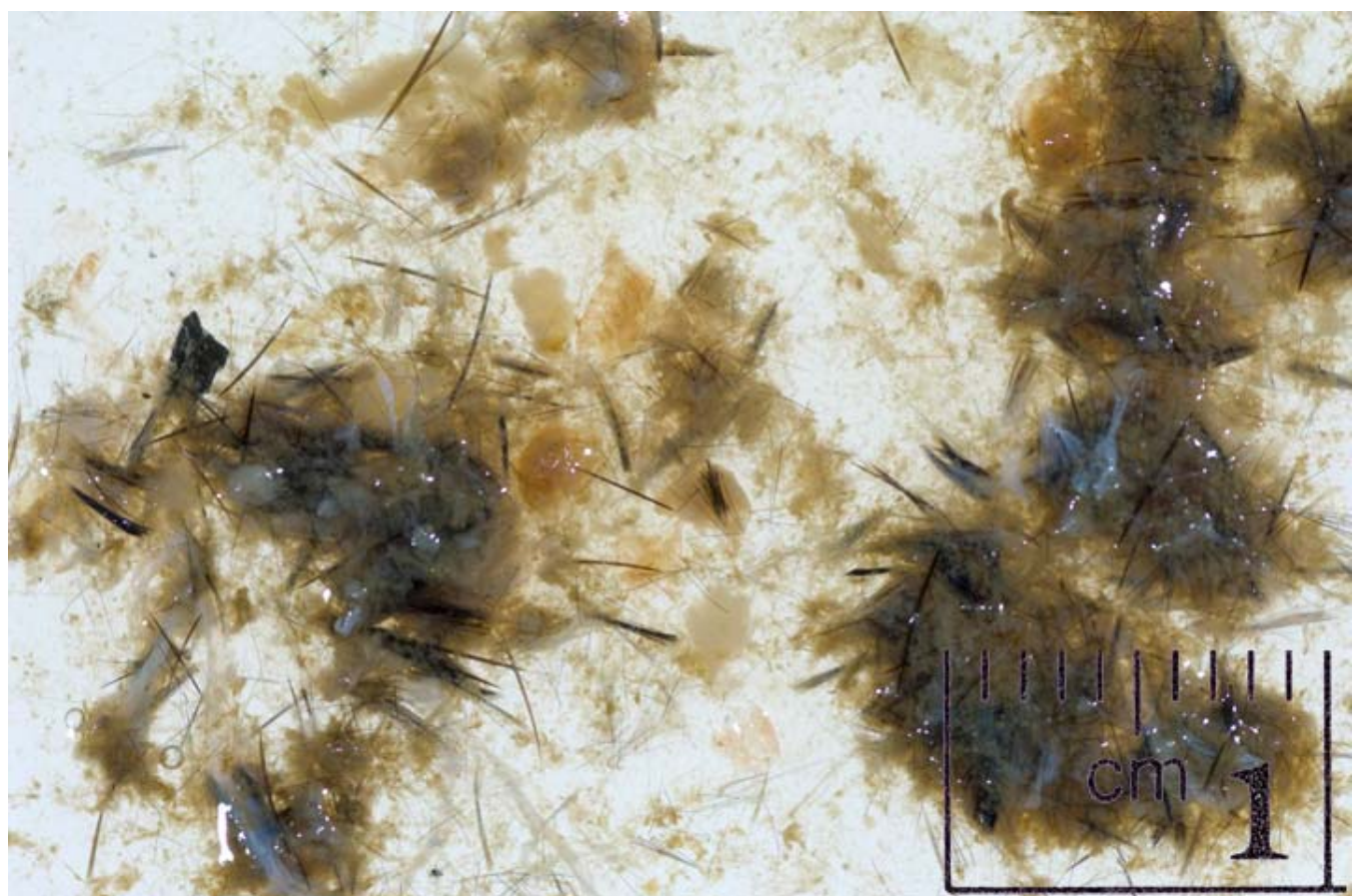

Figure 2.4 Image of polychaete chaetae from lower intestinal tract of Thermichthys hollisi. 


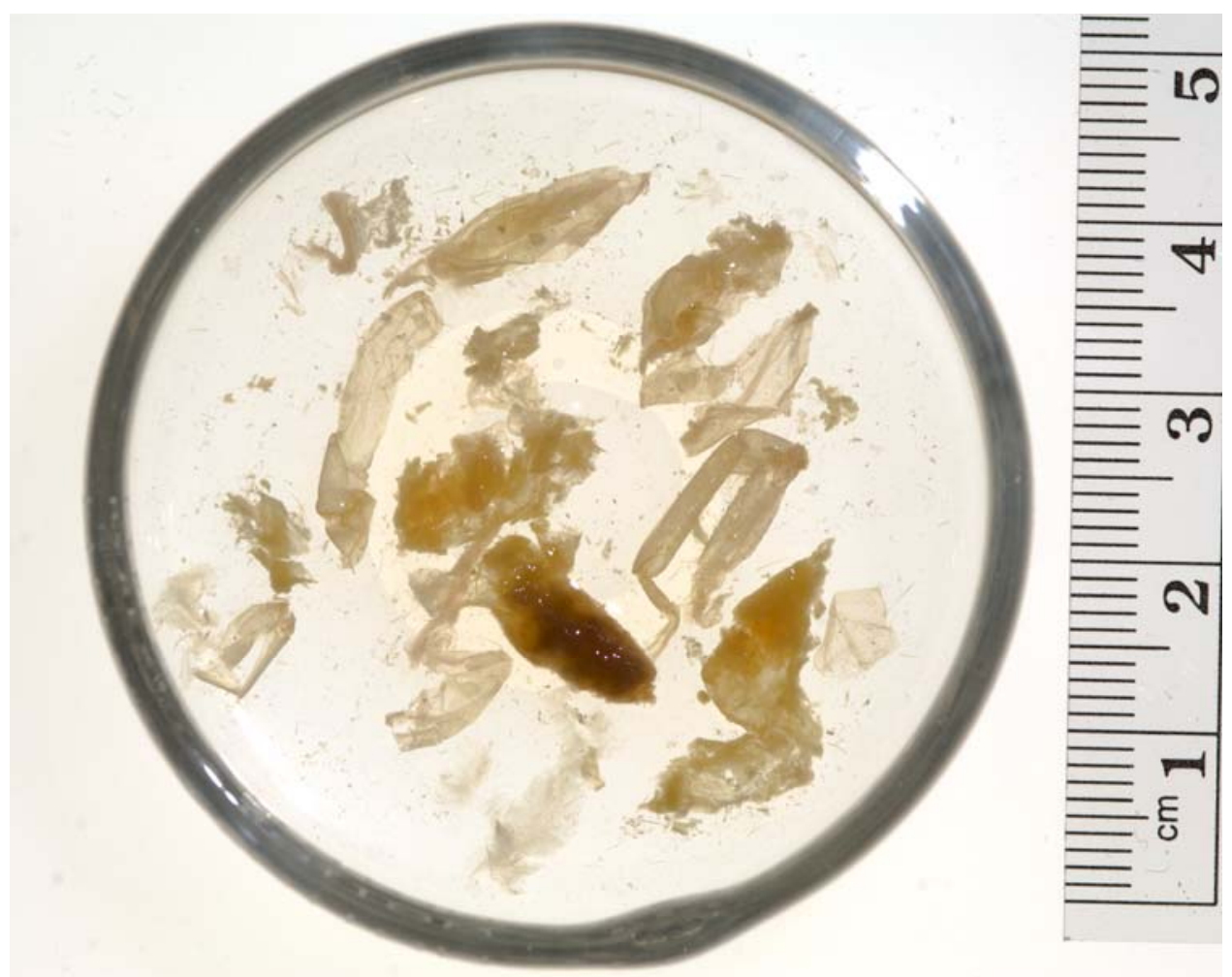

Figure 2.5 Crustacean exoskeleton from lower intestine of Thermichthys hollisi.

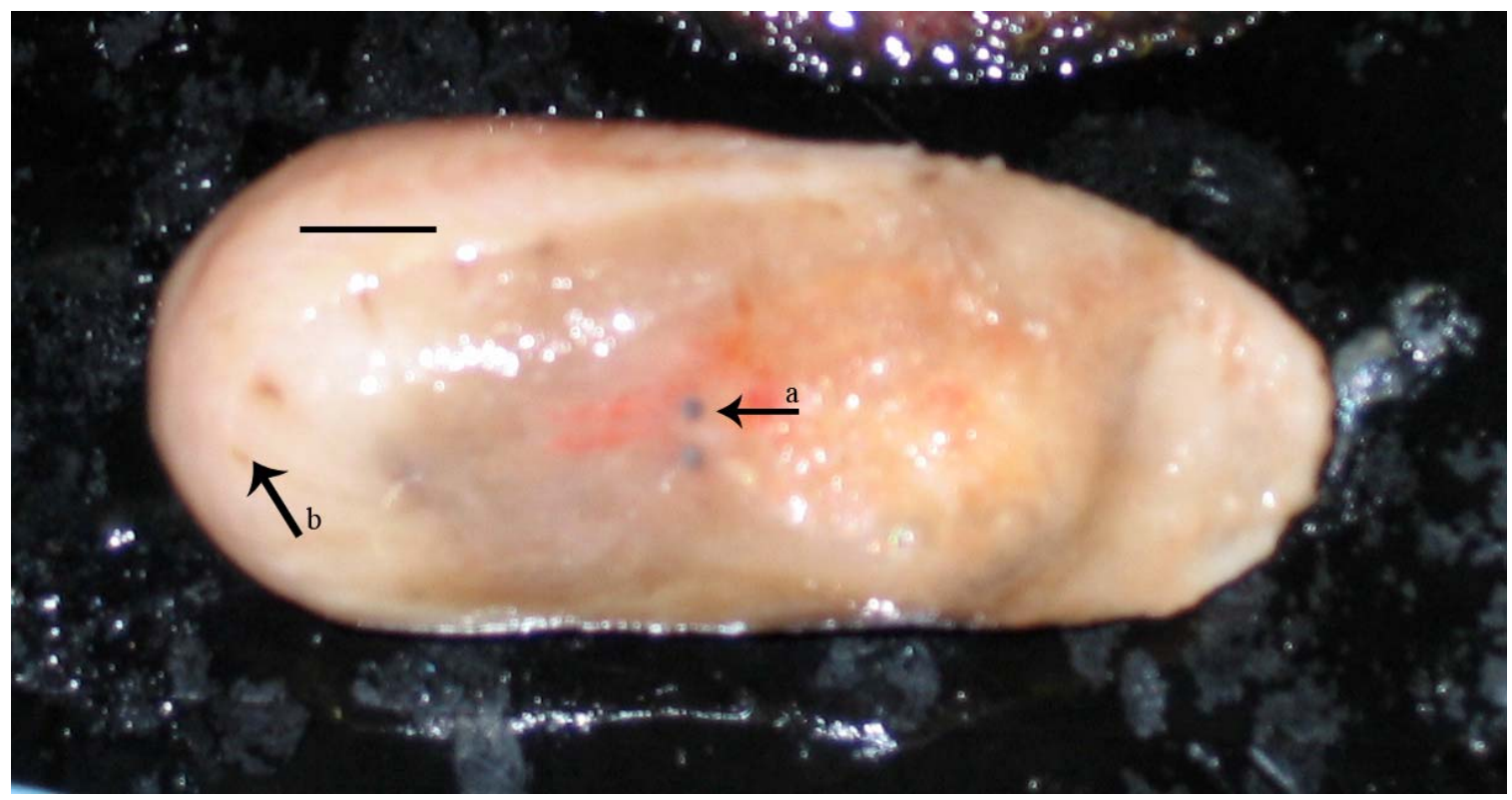

Figure 2.6 Alvinocaris lusca (arrow 'a' indicates an eye) and Thermarces cerberus (white tissue around outer edge, arrow 'b') from the stomach of Thermichthys hollisi. The scale bar is $1 \mathrm{~cm}$. 


\subsubsection{Isotope analyses}

Themichthys hollisi $\delta^{13} \mathrm{C}$ values ranged from -17 to $-9 \%$ and $\delta^{15} \mathrm{~N}$ values ranged from 9 to $13 \%$. The lipid normalization caused an approximate $5 \%$ shift in $\delta^{13} \mathrm{C}$ of the liver values, resulting in significantly $(\mathrm{p}<0.01)$ different carbon (but not nitrogen) ratios between liver and muscle tissue (Figure 2.7). The measured invertebrate values for both $\delta{ }^{13} \mathrm{C}$ and $\delta{ }^{15} \mathrm{~N}$ fell within the range established by previous studies. Vent invertebrates from $L$ vent only are depleted in nitrogen relative to T. hollisi values (Figure 2.8). T. hollisi $\delta^{34} \mathrm{~S}$ values ranged from -1 to $4 \%$, with vestimentiferan values falling below this and non-vestimentiferan vent invertebrates being relatively enriched (Figure 2.8). There is a significant difference $(\mathrm{p}<0.01)$ between sulfur signatures of $T$. hollisi liver and muscle tissues. Invertebrate data from sites other than L vent were also collected, as $T$. hollisi are mobile and thus presumably not limited to feeding only in one location. The data represented a minimum of three trophic levels with the lowest occupied by vestimentiferans and $B$. hessleri, the highest by fish and crabs, and the middle by a mix of invertebrate species (Figure 2.9). Both T. hollisi nitrogen and carbon data were intermediate in value to the measured vent invertebrates and to previously published values for non-vent, deep-sea invertebrates (Figure 2.9) (Van Dover \& Fry, 1989). When potential prey were broken into the broad taxonomic categories determined from gut content analysis, T. hollisi liver tissue appeared closest in carbon values to zoarcids, polychaetes and vestimentiferans, while muscle tissue most closely matched the isotopic ratios of limpets and shrimp (Figure 2.10). Even with the addition of non-L vent prey signatures, T. hollisi sulfur values remained depleted relative to most invertebrates, with 
the exception of the vestimentiferans and brachyuran crabs, and most closely matched the sulfur isotopic signature of zoarcids (Figure 2.10). The invertebrate sulfur signatures were similar to those presented in previous studies (Fry, et al., 1983; Brooks et al., 1987; Kennicutt et al., 1992; Mizota, 1997). The two-source mixing model indicated that chemosynthetically supported carbon sources could make up 64 to $100+\%$ of the diet based on muscle tissue values, and 78 to $100+\%$ based on liver tissue values. The Isosource model was not able to calculate any potential solutions using all three isotopes for the muscle values, but was able to resolve the liver values. The solution indicated that sources with mean isotopic signatures similar to those of zoarcids, crustaceans, and vestimentiferans had the greatest potential contribution to the diet as represented by $T$. hollisi liver values (Figure 2.11). 


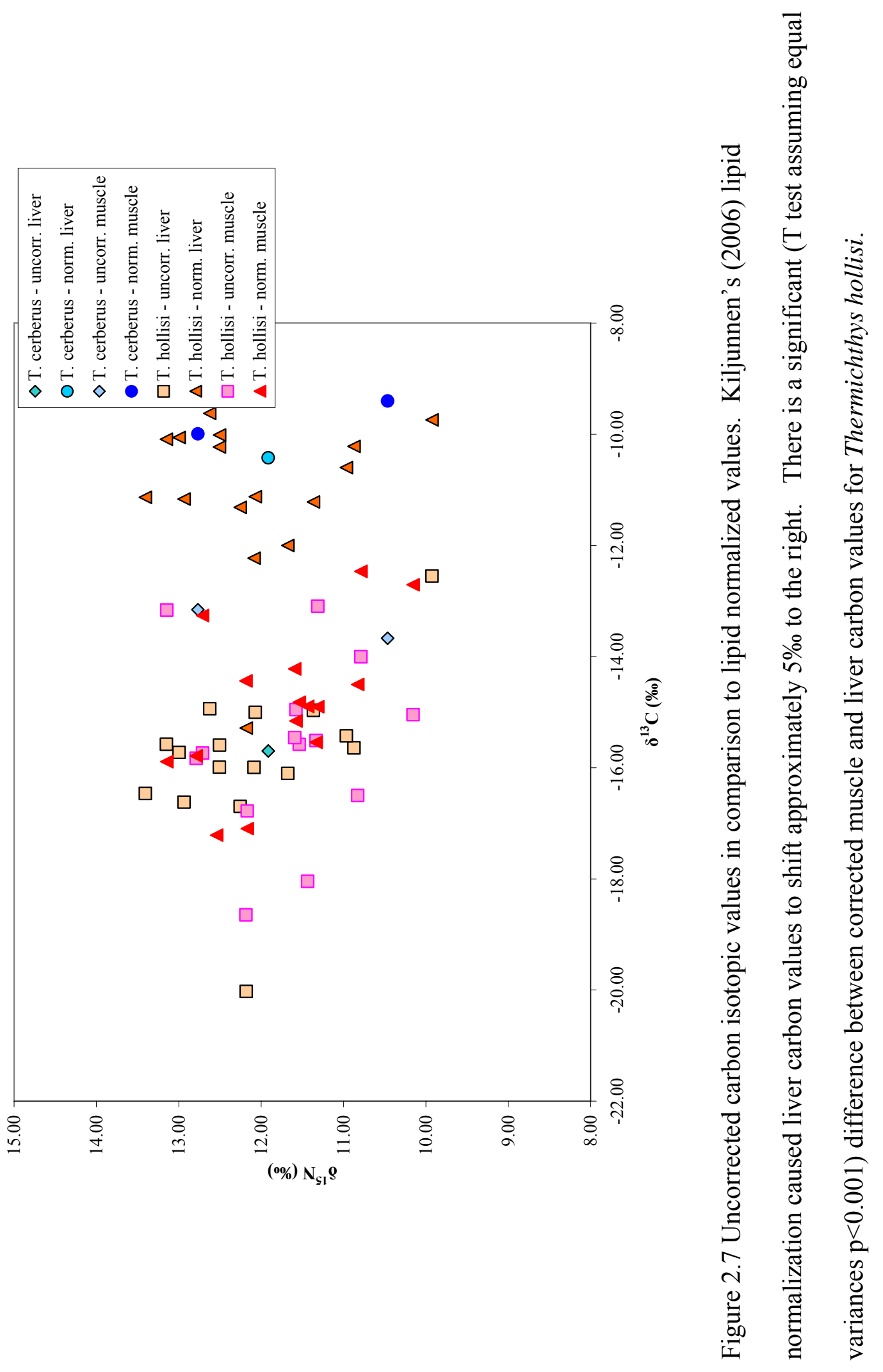




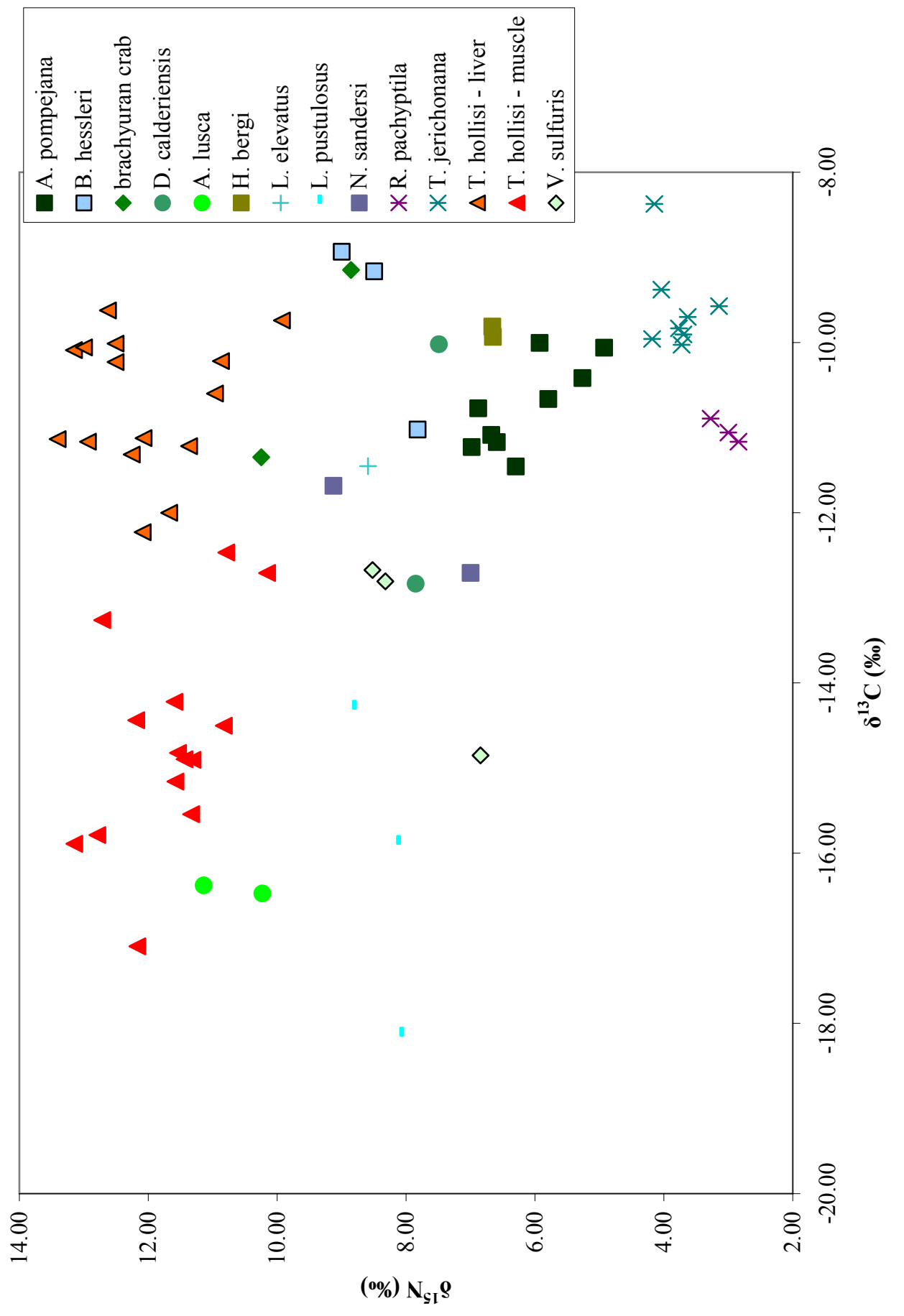

$\pi$
$\infty$
i 

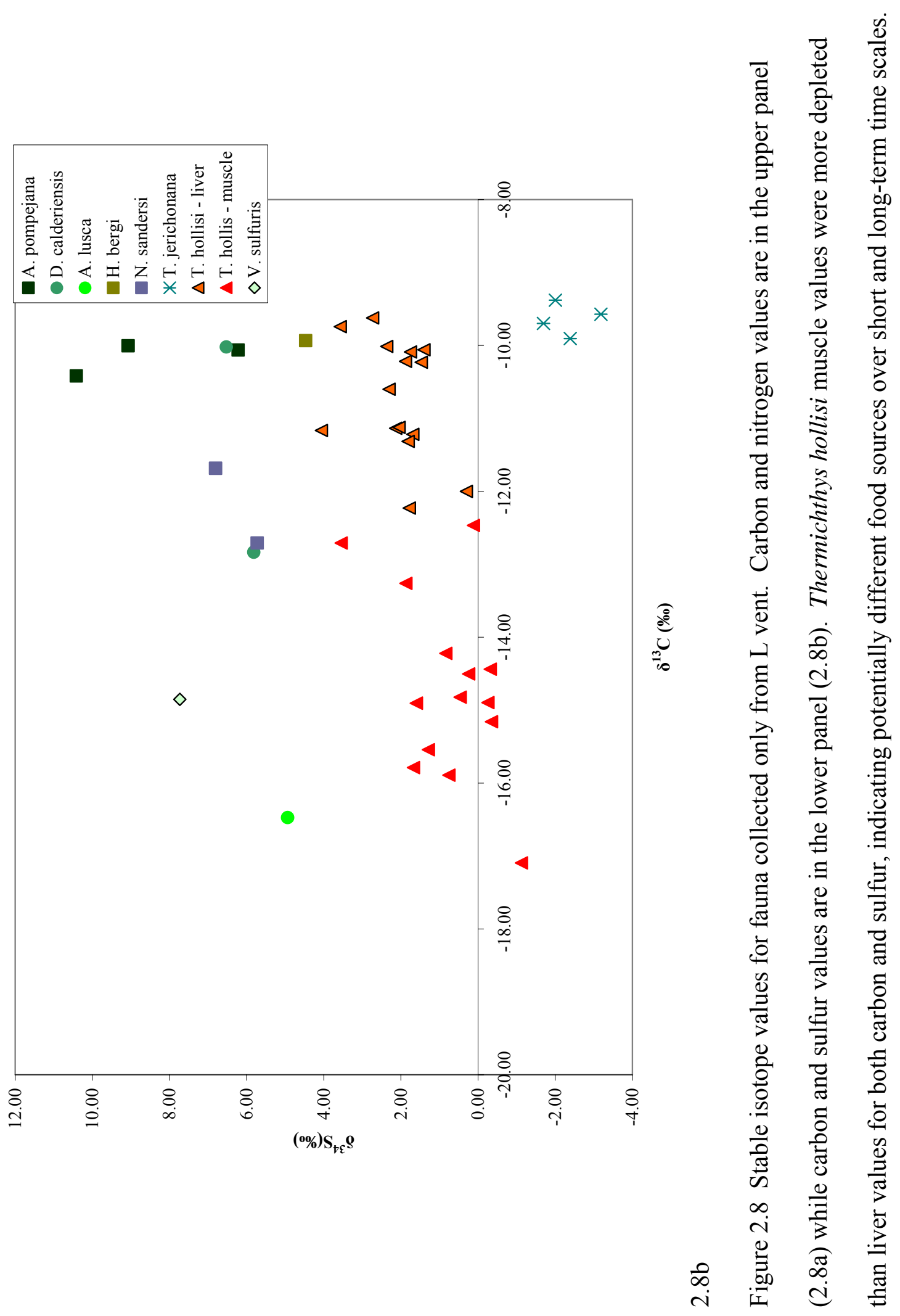


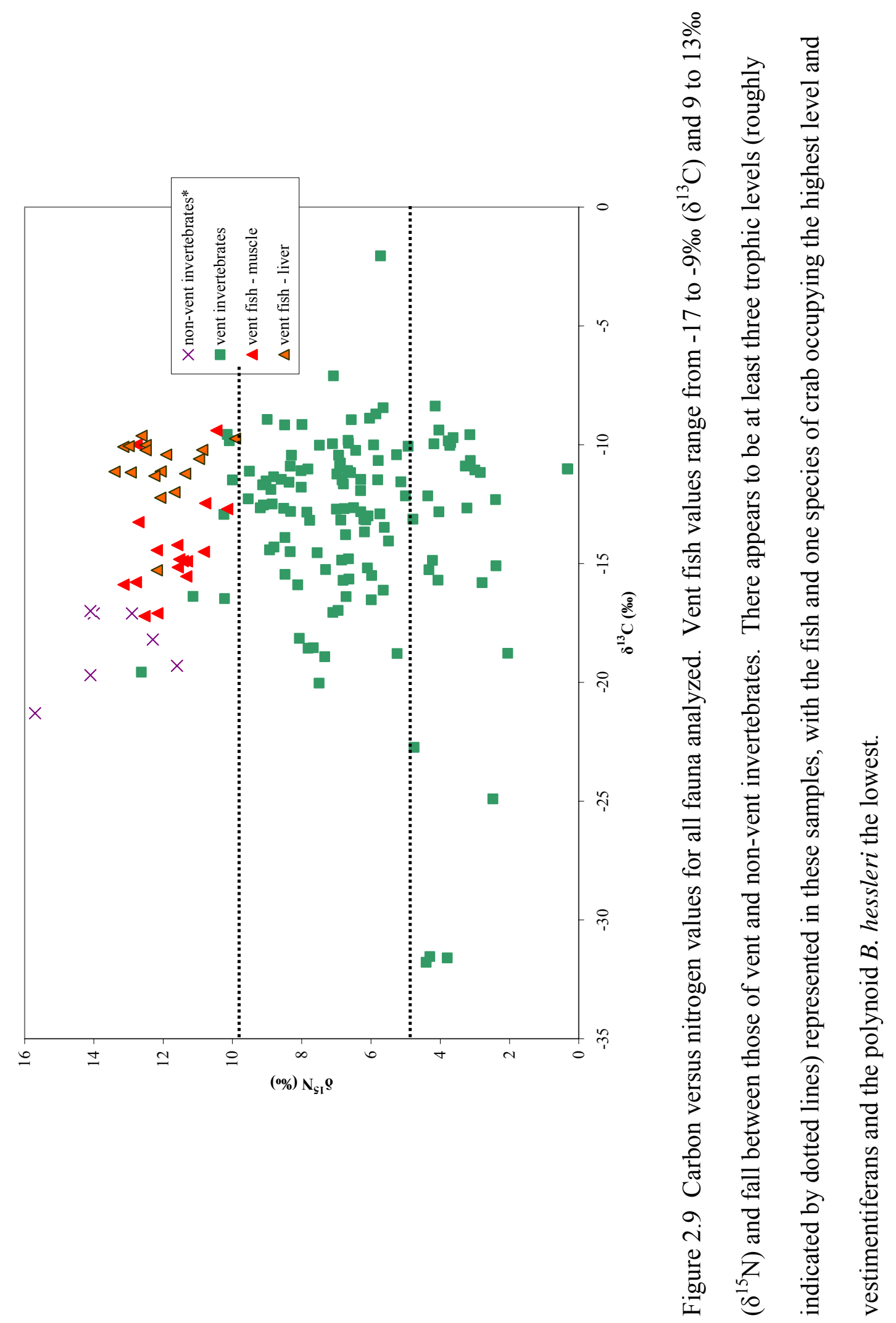




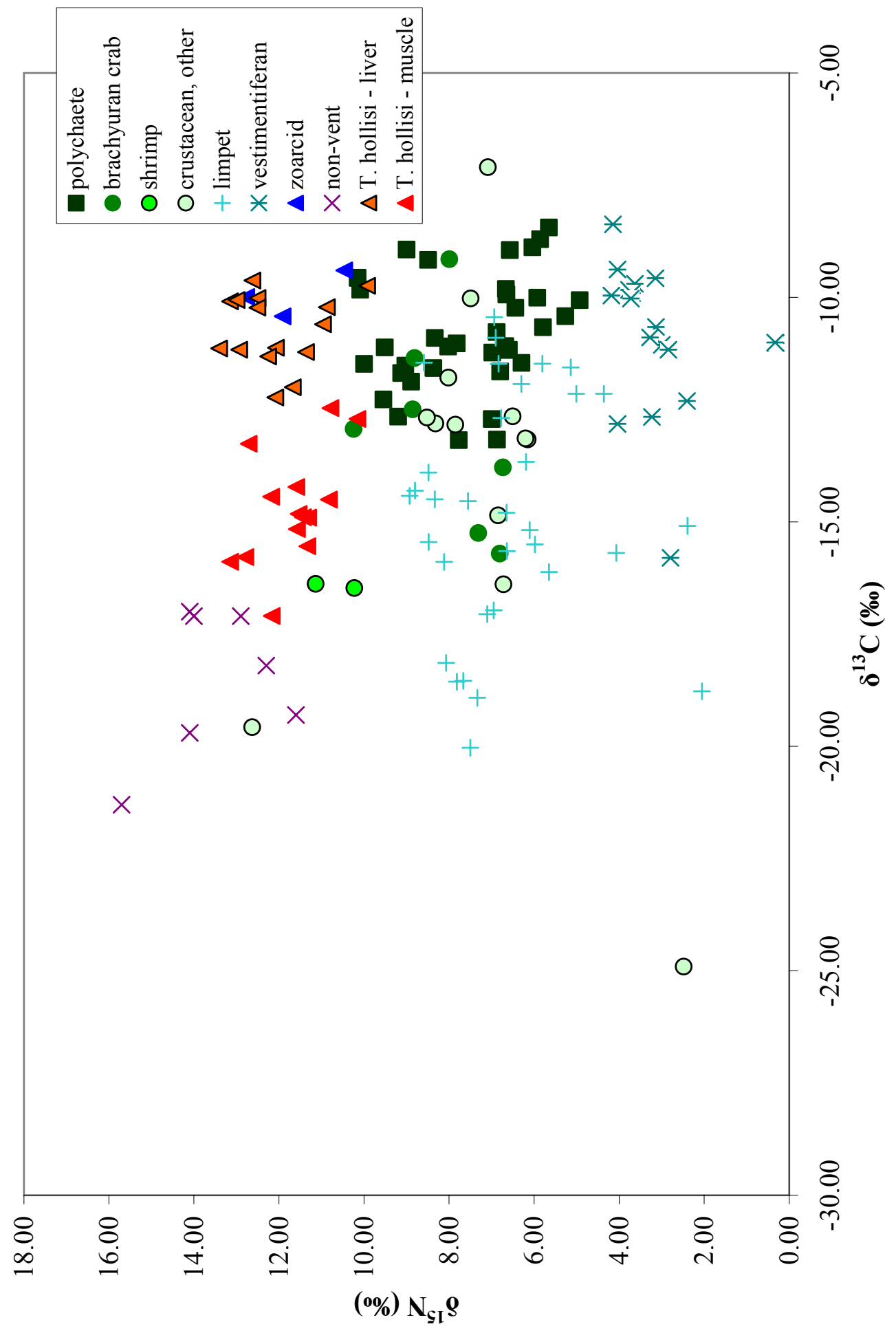

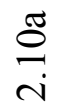




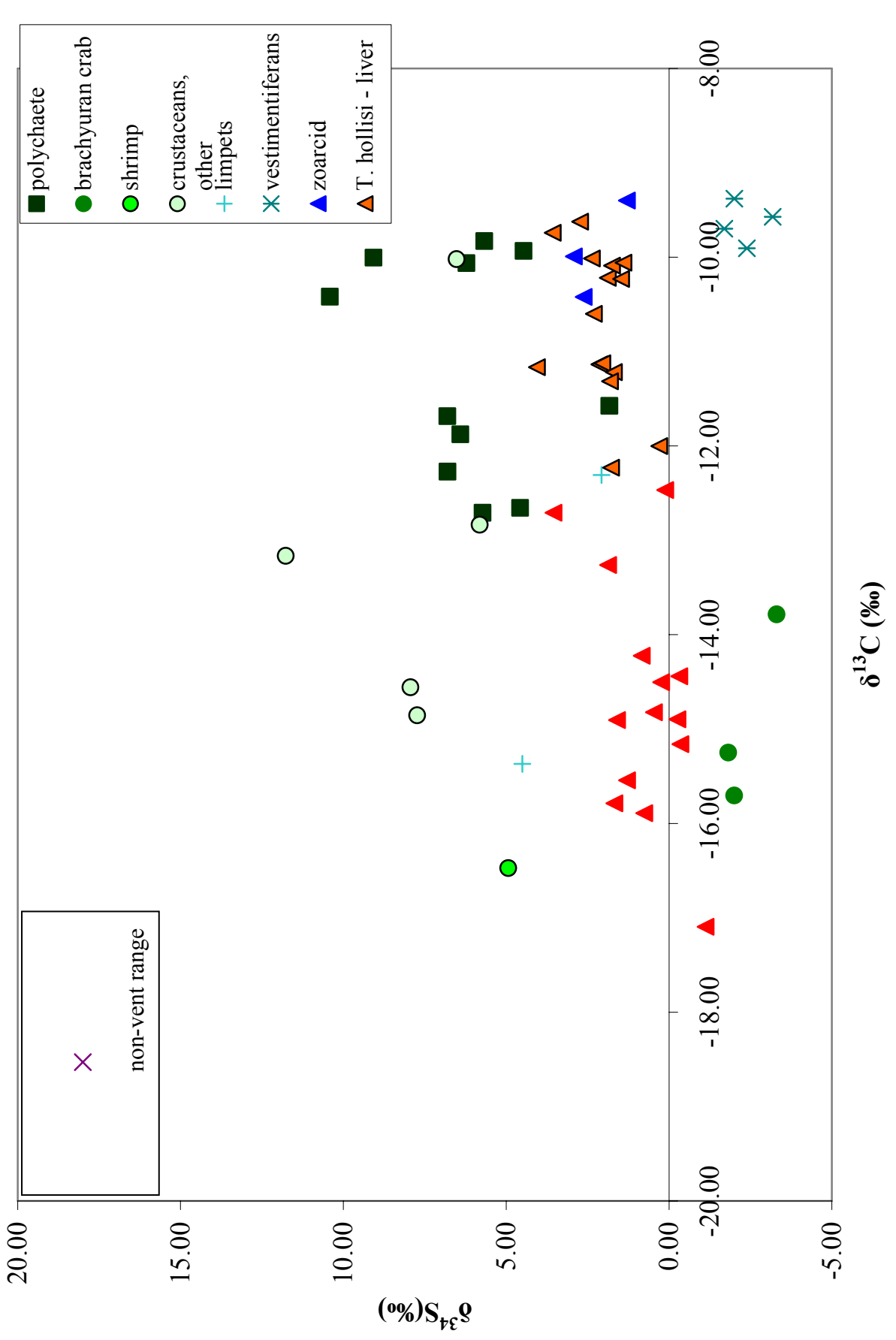

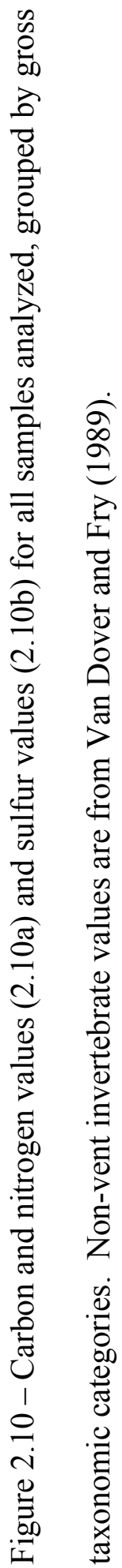




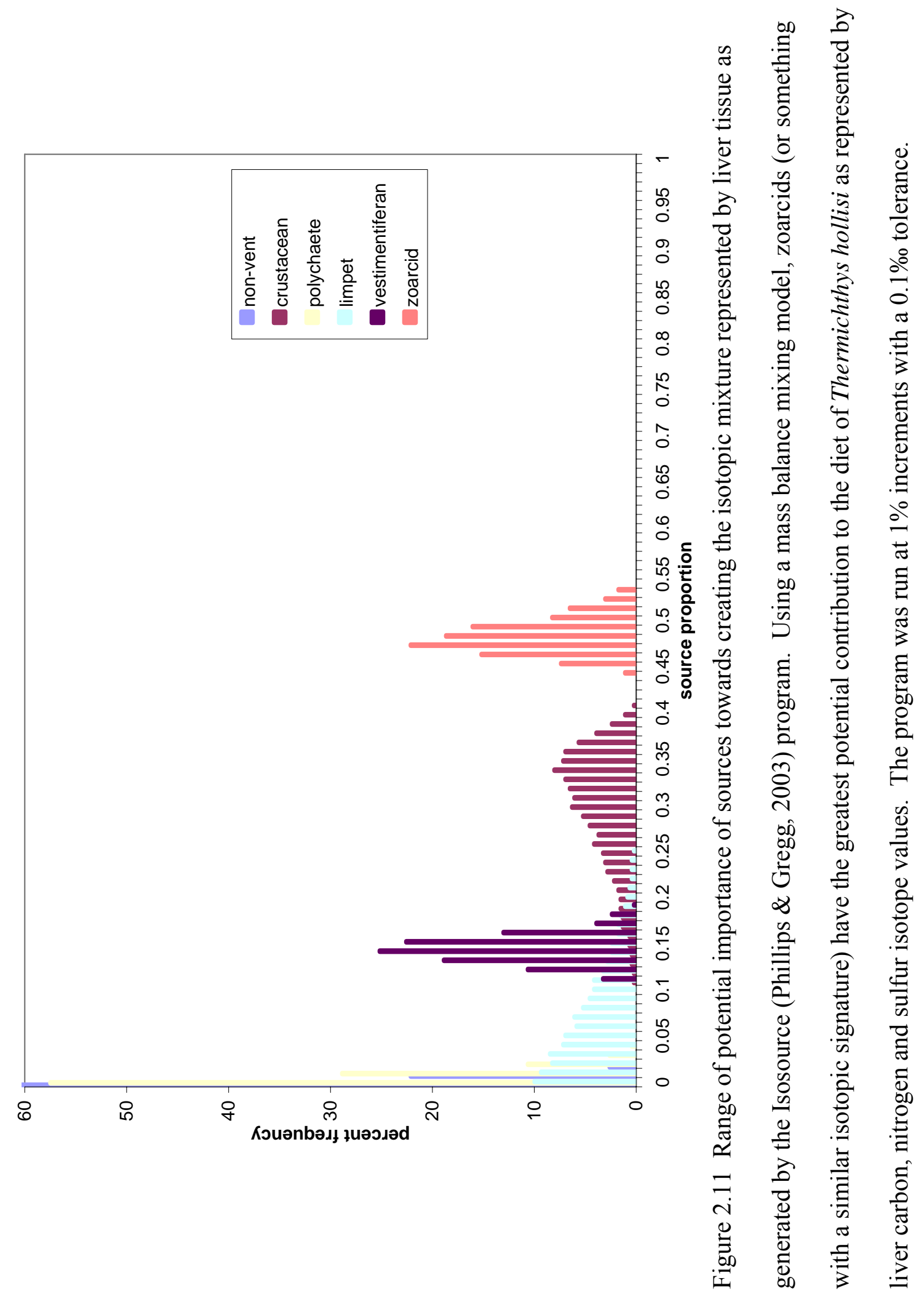




\subsection{Discussion}

The gut content analysis supports the hypothesis that Thermichthys hollisi prey upon species typically associated with hydrothermal vent environments, including the zoarcid Thermarces cerberus, the shrimp Alvinocaris lusca, and the crab Bythograea thermydron. The accompanying isotope data support this conclusion and allow for a more comprehensive look at T. hollisi prey preference and trophic ecology. The range of $\delta^{13} \mathrm{C}$ values for $T$. hollisi fall within areas that are covered by both vent and non-vent carbon sources, indicating that the fish may be utilizing both vent and non-vent carbon sources. This result is not entirely unexpected given that the fish is a large mobile predator that tends to be found more in the periphery of vent fields than directly in diffuse or direct flow areas.

As carbon values typically change little between trophic levels, it would appear that $T$. hollisi is utilizing more vent-produced carbon sources than non-vent. However, it must be remembered that interpretation of carbon isotope values can be influenced by tissue analyzed. $\delta^{13} \mathrm{C}$ values can be especially influenced by lipid content, as lipids have been found to be $\delta^{13} \mathrm{C}$ depleted, thus differences in lipid content between individuals and tissue types can lead to variation in $\delta^{13} \mathrm{C}$ values that are greater than the expected $1 \%$ difference between trophic levels, resulting in potential misinterpretations of trophic relationships. Various "lipid-correction" methods have been employed to counteract this, including both empirical and analytical methods. Lipid extraction methods typically utilize organic solvents such as chloroform/methanol to physically remove lipids from the 
tissue to be analyzed. These methods cause a change in $\delta^{15} \mathrm{~N}$ as well as $\delta^{13} \mathrm{C}$, and thus separate carbon and nitrogen analyses must be performed on both extracted and nonextracted tissues respectively (Sweeting et al., 2006). Murry et al. (2006) suggested that though lipid-extraction methods change both the carbon and nitrogen values and shift the placement of the food web, the extraction process does not alter interpretation of community structure. Lipid extraction methods can be disadvantageous to undertake in that they are often costly, time consuming, and require greater amounts of tissue than may be available (Sweeting et al., 2006). These disadvantages can be avoided by applying theoretical corrections (lipid-normalizations) based on C:N ratios measured within the tissues. Kiljunen et al. (2006) review the problems and processes associated with both empirical and theoretical lipid-corrections and offer a revised model for arithmetic lipid-normalization that is proposed to be valid across multiple fish taxa, but can be fine-tuned by testing against lipid-extraction data for a more species(or tissue)specific model. This study also suggested that lipid-normalization should be applied to aquatic fish but not invertebrates for use in mixing models (Kiljunen et al., 2006). The application of this revised lipid-normalization technique to the $T$. hollisi tissues resulted in a shift of liver carbon values approximately $5 \%$ heavier, and created a significant difference between average $T$. hollisi muscle and liver carbon values. This difference may represent changes in long-term versus short-term feeding habits. Perga and Gerdeaux (2005) hypothesized that fish liver tissue, due to its constant turnover, would be a better estimate of recent food consumption than muscle, whereas muscle would provide a more accurate long-term estimate. In the course of their study, they found 
evidence that seasonal dietary shifts may be better reflected in liver tissue. Both carbon and sulfur signatures showed significant differences between the two tissue types analyzed, which may reflect differences in diet or differences in tissue turnover. It is possible that the differences in muscle and liver tissue values could represent differences in long-term versus short-term feeding trends, as was hypothesized by Perga and Gerdeaux (2005).

It is typical to see only one size class (mean length of those collected was $33 \mathrm{~cm}$ with a standard deviation of $3 \mathrm{~cm}$ ) of Thermichthys hollisi in the venting areas (pers. obs.), leading one to hypothesize that the species may be migrating and feeding away from vents for part of their life cycle, explaining in part the different signatures evidenced by the muscle and liver tissues. It can also be hypothesized that $T$. hollisi is altering prey preference in response to prey availability. At the time of collection, $\mathrm{L}$ vent was home to numerous brachyuran crabs (Bythograea thermydron) (pers. obs.), potentially making the crabs an easy prey target for $T$. hollisi.

Regardless of these differences in carbon values between different tissues, both the gut content analyses and the carbon and nitrogen isotopic data indicated that Thermichthys hollisi is getting at least part (and more likely the majority) of its nutrition from chemosynthetically supported carbon sources. This conclusion is strongly supported by the sulfur isotope data. Tissue sulfur isotopic values are generally derived almost exclusively from dietary intake and do not typically fractionate between trophic levels, thus one would expect a similar value between prey and predator (Fry et al., 1983; Kennicutt et al., 1992). There are relatively few sulfur data for non-vent species within 
the study region, but species relying on photosynthetically-fixed carbon sources would be expected to have $\delta^{34} \mathrm{~S}$ values ranging from approximately 16 to $20 \%$, whereas those at vents trend toward 0\% (Mizota, 1997). Sulfur values for T. hollisi are surprisingly depleted, falling below the proposed 5\% limit delineating chemoautotropic organisms (Vetter \& Fry, 1998). Of the data measured in this study, only the vestimentiferan Tevnia jerichonana and the crab Bythograea thermydron are more depleted than the fish. Invertebrate measurements are consistent with previous studies (Fry, et al., 1983; Brooks et al., 1987; Kennicutt et al., 1992; Mizota, 1997). The depleted (near 0\%o) sulfur signatures of the fish tissues indicate that they are consuming prey items that are associated with venting environments. The simple two-source mixing model for the sulfur data alone indicates a dietary fraction of $88 \%$ from a chemosynthetic source, additionally supporting the conclusion that $T$. hollisi is feeding almost entirely upon ventendemic fauna. However, the sulfur signatures of T. hollisi tissues do not exactly match any of the vent invertebrates measured, indicating a need for additional sulfur isotope data from vent fauna to further clarify which prey sources provide the greatest dietary contribution.

The gut content analyses and the nitrogen data support the hypothesis that Thermichthys hollisi are high trophic level predators within the vent ecosystem, extending the existing knowledge of energy transfer within the system. As a large predator, T. hollisi has the potential to affect the community composition of their environment. Recorded observations of T. hollisi do not indicate that the species is particularly widespread, but where they are located they are typically abundant, and thus 
may be affecting localized, but not widespread community dynamics and composition through their feeding habits. In particular, the present study shows that the zoarcid Thermarces cerberus substantially contributes to the diet of $T$. hollisi. It can be hypothesized that $T$. hollisi directly affects the density of zoarcids and thus indirectly affects gastropod populations through the removal of $T$. cerberus within a localized area. Manipulative experiments would be useful to determine the effect of $T$. hollisi predation (or lack thereof) on the localized community composition and structure. The information garnered within the scope of this study allows for a more comprehensive view of trophic networks and the flow of energy within the venting system on the East Pacific Rise (Figure 2.12), particularly expanding the identity of upper trophic level predators. 


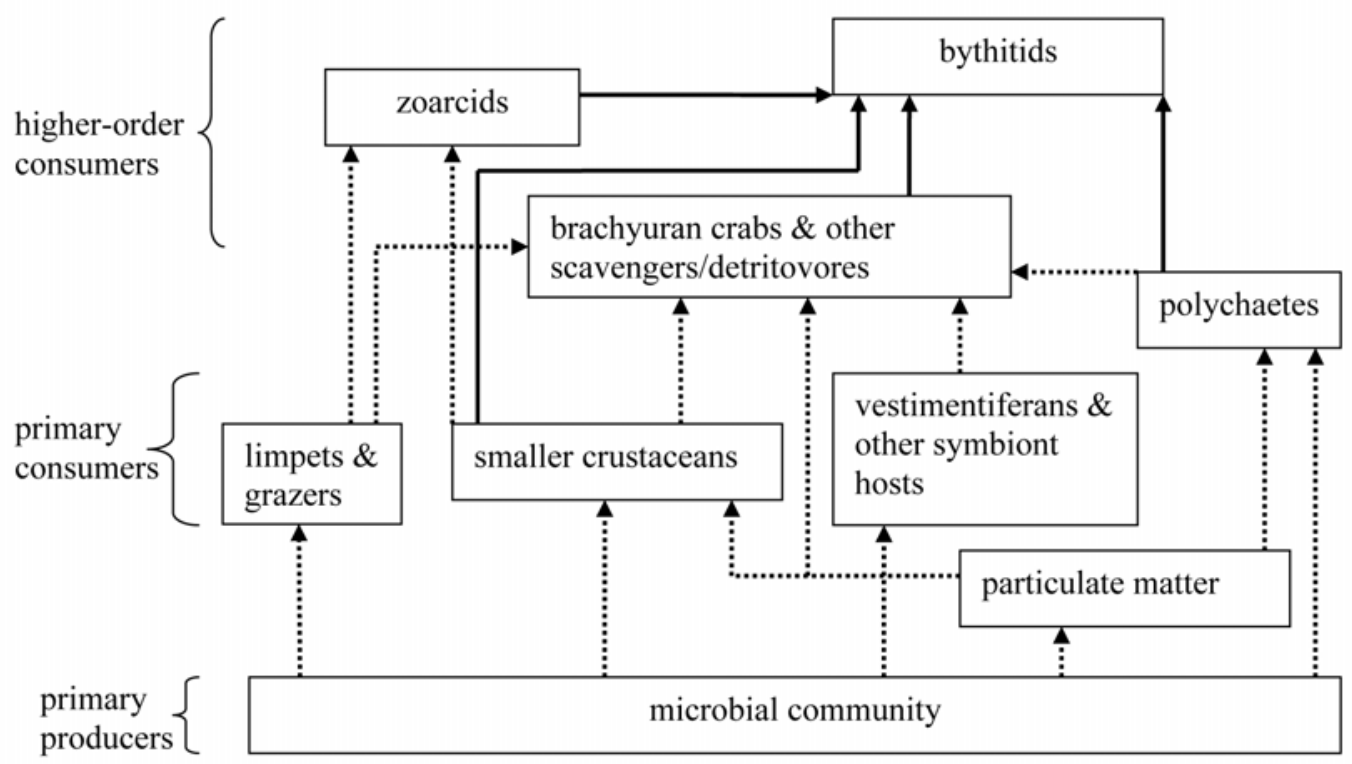

Figure 2.12 Hypothesized transfer of energy through trophic levels at venting communities on the East Pacific Rise. Solid arrows represent data from this study, dotted lines are inferred from this and previous work. (Modified from Bergquist et al., 2007).

\section{Summary}

This study offers the first direct evidence of Thermichthys hollisi prey choice and dependence upon the chemosynthetically supported vent communities for nutrition; and supports the hypothesis that this species of fish is an upper trophic level predator within the venting environments on the East Pacific Rise. As such they have the potential to both directly and indirectly affect the surrounding invertebrate community population density, composition, and structure. 


\section{Chapter 2 References}

Barrett RT, Krasnov YV (1996) Recent responses to changes in stocks of prey species by seabirds breeding in the southern Barents Sea. ICES J Mar Sci 53: 713-722.

Bechara JA, Planas D, Paquet S (2007) Indirect effects of brook trout (Salvelinus fontinalis) on the structure of epilithic algal communities in an oligotrophic boreal forest

Bergquist DC, Eckner JT, Urcuyo IA, Cordes EE, Hourdez S, Macko SA, Fisher CR (2007) Using stable isotopes and quantitative community characteristics to determine a local hydrothermal vent food web. Mar Ecol Prog Ser 330:49-65.

Bologna, PAX (2007) Impact of differential predation potential on eelgrass (Zostera marina) faunal community structure. Aquat Ecol 41:221-229.

Brooks JM, Kennicutt MC, Fisher CR, Macko SA, Cole K, Childress JJ, Bidigare RR, Vetter RD (1987) Deep-Sea Hydrocarbon Seep Communities: Evidence for Energy and Nutritional Carbon Sources. Science 238(4830):1138-1142.

Bundy A (2005) Structure and functioning of the eastern Scotian Shelf ecosystem before and after the collapse of groundfish stocks in the early 1990s. Can J Fish Aquat Sci 62: 1453-1473.

Carpenter RC (1988) Mass mortality of a Caribbean sea urchin: Immediate effects on community metabolism and other herbivores. Proc Nat Acad Sci USA 85: 511514.

Ceccarelli DM, Jones GP, McCook LJ (2005) Foragers versus farmers: contrasting effects of two behavioural groups of herbivores on coral reefs. Oecologia $145: 445-453$.

Clark RG, Hobson KA, Wassenaar LI (2006) Geographic variation in the isotopic (delta $\mathrm{D}$, delta super(13)C, delta super(15)N, delta super(34)S) composition of feathers and claws from lesser scaup and northern pintail: implications for studies of migratory connectivity. Can J Zool 84(10): 1395-1401.

Colaço A, Dehairs F, Desbruyères D (2002) Nutritional relationships of deep-sea hydrothermal fields at the Mid-Atlantic Ridge: a stable isotope approach. DeepSea Res I 49:395-412.

Davenport AC, Anderson TW (2007) Positive indirect effects of reef fishes on kep performance: the importance of mesograzers. Ecology 88(6):1548-1561

DeNiro JM, Epstein S (1978) Influence of diet on the distribution of carbon isotopes in animals. Geochim Cosmochim Acta 42: 495-506.

Desbruyères D, Segonzac M, Bright M (Editors; 2006) Handbook of Deep-Sea Hydrothermal Vent Fauna. Second completely revised edition. Denisia 18: 544pp.

Estes JE, Smith NS, Palmisana JF (1978) Sea Otter Predation and Community Organization in the Western Aleutian Islands. Ecology 59(4): 822-833.

Fisher CR, Childress JJ, Macko SA, Brooks JM (1994) Nutritional interaction in Galapagos Rift hydrothermal vent communities: inferences from stable carbon and nitrogen isotope analyses. Mar Ecol Prog Ser 103:45-55. 
Fisher CR, Kennicutt II MC, Brooks JM (1990) Stable Carbon Isotopic Evidence for Carbon Limitation in Hydrothermal Vent Vestimentiferans. Science 247(4946):1094-1096.

Fry B, Gest H, Hayes JM (1983) Sulphur isotopic compositions of deep-sea hydrothermal vent animals. Nature 306:52-52.

Gannes LZ, del Rio CM, Koc P (1998) Natural Abundance Variations in Stable Isotopes and their Potential Uses in Animal Physiological Ecology. Comp Biochem Physiol 119A(3) 725-737.

Geistdoerfer P (1998) Ichthyofaunes des Communautes Chimiosynthétiques Marines. Ann Inst Océanogr 74(2): 201-215.

Gloeckner DR, Luczkovich JJ (2008) Experimental assessment of trophic impacts from a network model of a seagrass ecosystem: Direct and indirect effects of gulf flounder, spot and pinfish on benthic polychaetes. J Exp Mar Biol Ecol 357:109120.

Guidetti P (2007) Predator diversity and density affect levels of predation upon strongly interactive species in temperate rocky reefs. Oecologia 154:513-520.

Hadwen WL, Russell GL, Arthington AH (2007) Gut content- and stable isotope-derived diets of four commercially and recreationally important fish species in two intermittently open estuaries. Mar Fresh Res 58:363-375.

Hobson KA (1999) Tracing origins and migration of wildlife using stable isotopes: a review. Oecologia 120:314-326.

Hughes TP (1994) Catastrophes, Phase Shifts, and Large-Scale Degradation of a Caribbean Coral Reef. Science 265(5178): 1547-1551.

Kennicutt II MC, Burke Jr RA, MacDonald IR, Brooks JM, Denoux GJ, Macko SA (1992) Stable isotope partitioning in seep and vent organisms: chemical and ecological significance. Chem Geol 101:293-310.

Kiljunen M, Grey J, SinisaloT, Harrod C, Immonen H, Jones RI (2006) A revised model for lipid-normalizing $\delta^{13} \mathrm{C}$ values from aquatic organisms, with implications for isotope mixing models. J App Ecol 43:1213-1222.

Lindeman RL (1942) The trophic-dynamic aspect of ecology. Ecology 23: 399-418.

Luther GW, Rozan TF, Taillerfert M, Nuzzio DB, Di Meo C, Shank TM, Lutz RA, Cary SC (2001) Chemical speciation drives hydrothermal vent ecology. Nature 410: 813-816.

MacAvoy SE, Macko SA, Garman GC (1998) Tracing Marine Biomass into Tidal Freshwater Ecosystems Using Stable Sulfur Isotopes. Naturwissenschaften 85: 544-546.

MacAvoy SE, Carney RS, Fisher CR, Macko SA (2002) Use of chemosynthetic biomass by large, mobile, benthic predators in the Gulf of Mexico. Mar Ecol Prog Ser 225:65-78.

MacAvoy SE, Fisher CR, Carney RS, Macko SA (2005) Nutritional associations among fauna at hydrocarbon seep communities in the Gulf of Mexico. Mar Ecol Prog Ser 292:51-60.

MacAvoy SE, Macko SA, Garman GC (2001) Isotopic turnover in aquatic predators: quantifying the exploitation of migratory prey. Can J Fish Aquat Sci 58:923-932. 
McConnaughey T, McRoy CP (1979) ${ }^{13} \mathrm{C}$ Label Identifies Eelgrass (Zostera marina) Carbon in an Alaskan Estuarine Food Web. Mar Biol 53:263-269.

Meyer CP, Geller JB, Paulay G (2005) Fine scale endemism on coral reefs: Archipelagic differentiation in turbinid gastropods. Evolution 59(1): 113-125.

Micheli F, Peterson CH, Mullineaux LS, Fisher CR, Mills SW, Sancho G, Johnson GA, Linihan HS (2002) Predation structures communities at deep-sea hydrothermal vents. Ecol Mono 72(3):365-382.

Minigawa M, Wada E (1984) Stepwise enrichment of $15 \mathrm{~N}$ along food chains: further evidence and the relation between $15 \mathrm{~N}$ and animal age. Geochim Cosmochim Acta 48: 1135-1140.

Mizota C (1997) An inventory of sulfur isotopic characterization of the hydrogen sulfidedependent, marine benthic biological community. JAMSTEC J Deep Sea Res 13:711-720.

Mullineaux LS, Fisher CR, Peterson CH, Schaeffer SW (2000) Tubeworm Succession at Hydrothermal Vents: Use of Biogenic Cues to Reduce Habitat Selection Error? Oecologia 123(2): 275-284.

Murry BA, Farrell JM, Teece MA, Smyntek PM (2006) Effect of lipid extraction on the interpretation of fish community trophic relationships determined by stable carbon and nitrogen isotopes. Can J Fish Aquat Sci 63:2167-2172.

Perga ME, Gerdeaux D (2005) 'Are fish what they eat' all year round? Oecologia 144:598-606.

Peterson BJ, Fry B (1987) Stable Isotopes in Ecosystem Studies. Ann Rev Ecol System 18: 293-320.

Phillips DL, Gregg JW (2003) Source partitioning using stable isotopes: coping with too many sources. Oecologia 136:261-269.

Pinnegar JK, Polunin NVC, Francour P, Balamenti F, Chemello R, Harmelin-Vivien ML, Hereu B, Milazzo M, Zabala M, D’Anna G, Pipitone C (2000) Trophic cascades in benthic marine ecosystems: lessons for fisheries and protected-area management. Environ Conserv 27(2):179-200.

Pond DW, Fallick AE, Stevens CJ, Morrison DJ, Dixon DR (2008) Vertebrate nutrition in a deep-sea hydrothermal vent ecosystem: Fatty acid and stable isotope evidence. Deep-Sea Res I 55:1718-1726.

Quijón PA, Snelgrove PVR (2005) Predation regulation of sedimentary faunal structure: potential effects of a fishery-induced switch in predators in a Newfoundland subArctic fjord. Oecologia 144:125-136.

Rau GH (1981) Hydrothermal vent clam and tubeworm ${ }^{13} \mathrm{C} /{ }^{12} \mathrm{C}$; Further evidence of nonphotosynthetic food sources. Science 213: 338-340.

Rau GH, Hedges JI (1979) Carbon-13 depletion in a hydrothermal vent mussel: Suggestion of a chemosynthetic food source. Science 203: 648-649.

Rees CE, Jenkins WJ, Monster J (1978) The sulphur isotopic composition of ocean water sulphate. Geochim Cosmochim Acta 42: 377-381.

Saino T, Ohta S $(1989){ }^{13} \mathrm{C} /{ }^{13} \mathrm{C}$ and ${ }^{13} \mathrm{~N} /{ }^{14} \mathrm{~N}$ ratios of vesicomyid clams and a vetimentiferan tube worm in the subduction zone East of Japan. Palaeogrog Palaeoclimat Palaeoecol 71: 169-178. 
Sancho G, Fisher CR, Mills S, Micheli F, Johnson GA, Lenihan HS, Peterson CH, Mullineaux LS (2005) Selective predation by the zoarcid fish Thermarces cerberus at hydrothermal vents. Deep-Sea Res I 52:837-844.

Savenkoff C, Castonguay M, Chabot D, Hammill MO, Bourdages H, Morissette L (2007) Changes in the northern Gulf of St. Lawrence ecosystem estimated by inverse modeling: Evidence of a fishery-induced regime shift? Est Coast Shelf Sci 73: 711-724.

Shank TM, Fornari DJ, Von Damm KL, Lilley MD, Haymon RM, Lutz RA (1998) Temporal and spatial patterns of biological community development at nascent deep-sea hydrothermal vents (950’N, East Pacific Rise). Deep-Sea Res II 45: 465-515.

Shanks III WC, Bölke JK, Seal II RR (1995) Stabel Isotopes in Mid-Ocean Ridge Hydrothermal Systems: Interactiosn Between Fluids, Minerals, and Organisms. In: Humphris SE, Zierenberg RA, Mullineaux LS, Thomson RE (eds) Seafloor Hydrothermal Systems Physical, Chemical, Biological, and Geological Interactions. AGU pp 194-221.

Sweeting CJ, Polunin NVC, Jennings S (2006) Effects of chemical lipid extraction and arithmetic lipid correction on stable isotope ratios of fish tissues. Rapid Commun Mass Spectrom 20:595-601.

Tarboush RA, MacAvoy SE, Macko SA, Connaughton V (2006) Contribution of catabolic tissue replacement to the turnover of stable isotopes in Danio rerio. Can J Zool 84(10): 1453-1460.

Van Dover CL (2002) Trophic relationships among invertebrates at the Kairei hydrothermal vent fields (Central Indian Ridge). Mar Biol 141:761-772.

Van Dover CL, Fry B (1989) Stable isotopic compositions of hydrothermal vent organisms. Mar Biol 102:257-263.

Van Dover CL, Fry B (1994) Microorganisms as food resources at deep-sea hydrothermal vents. Limnol Ocean 39: 51-57.

Vetter RD, Fry B (1998) Sulfur contents and sulfur isotope composition of thiotrophic symbioses in bivalve molluscs and vestimentiferan worms. Mar Biol 132: 453460.

Williams PM, Smith KL, Druffel EM, Linick TW (1981) Dietary carbon sources of mussels and tubeworms from Galapagos hydrothermal vents determined from tissue ${ }^{14} \mathrm{C}$ activity. Nature 292: 448-449.

Winemiller KO, Akin S, Zeug SC (2007) Production sources and food web structure of a temperat tidal estuary: integration of dietary and stable isotope data. Mar Ecol Prog Ser 343:63-76.

Worm B, Meyers RA (2003) Meta-analysis of cod/shrimp interactions reveals top-down control in oceanic food webs. Ecology 84: 162-173.

Yamanaka T, Mizota C, Shimoyama S (2003) Sulfur isotopic variation in soft tissues of five benthic animals from the reductive, tidal-flat sediments in northern Kyushu, Japan. Mar Biol 142:327-331. 


\title{
Chapter Three
}

\section{Otolith Isotope Chemistry of Hydrothermal Vent Fish:}

\author{
Insights into Habitat Use and Life History Strategy
}

\begin{abstract}
Laser-ablation ICPMS was used to analyze otolith isotope chemistry of hydrothermal vent-endemic fish for the first time. Strontium, barium, lithium and magnesium were measured with the greatest accuracy and showed significant differences between both species of vent fish (Thermarces cerberus and Thermichthys hollisi) and non-vent specimens analyzed. The influence of exposure to hydrothermal fluid is apparent in otoliths from both species of vent fish, most noticeably within the relatively elevated $\mathrm{Sr}: \mathrm{Ca}$ and depleted $\mathrm{Mg}$ :Ca ratios. Otolith chemistry suggests that $T$. cerberus experiences greater direct exposure to diffuse fluids than does T. hollisi, which is consistent with apparent habitat preferences. Isotopic patterns across the span of the otolith suggest that $T$. cerberus spends its entire life within the vent system. In contrast it appears that $T$. hollisi exists outside of the influence of hydrothermal activity for some early portion of its life-cycle.
\end{abstract}

\subsection{Introduction}

Since the discovery of hydrothermal vents and their associated biological communities, biological studies have largely focused on understanding the physiology, evolution, adaptation, larval dispersal, trophic relationships and connectivity of the ventendemic fauna (Childress \& Fisher, 1992; Vrijenhoek, 1997; Tyler \& Young, 1999). An area of particular interest that has proven challenging to study is the clarification of life history strategies employed by vent fauna, beyond the basic categorization of larval type and the inferred dispersal and gene flow. Research in these areas has focused on vent invertebrates, with no prior studies dedicated to studying the life history of the ventendemic vertebrate fauna on the East Pacific Rise (EPR). Two species of fish are considered endemic to vents on the EPR, the zoarcid Thermarces cerberus (Rosenblatt \& Cohen, 1986) and the bythitid Thermichthys hollisi (Cohen et al., 1990). Both T. cerberus and T. hollisi are considered dependent upon vent communities for nutrition 
(Micheli et al., 2002; Sancho et al, 2005; Buckman \& Shank, in prep). As top predators within the system, vent fish have the ability to influence species composition and abundance of lower trophic levels. Despite this ecological importance, little is known regarding their life history. T. hollisi typically occupies the periphery of vent fields, particularly in "fish holes" (collapse pits or cracks in the basalt where fish aggregate), but there are no recorded observations of different size classes. It is common to observe multiple sizes (and presumably ages) of the zoarcid Thermarces cerberus (Shank et al., 1998), suggesting that as a species T. cerberus spends its entire life cycle within the vent field while $T$. hollisi may migrate outside the vent field for some portion of its existence. Difficulties in observing deep-sea fish in situ, as well as challenges to capturing them in relevant numbers, make ecological studies challenging and elusive. When unable to observe an organism directly to learn about its biology and life strategy, tools such as tags, tracers, and/or population genetic techniques can be employed to approximate life histories and migrations. The study of otolith (fish ear bone) chemical composition is an effective alternative approach to direct observation in order to elucidate the life histories of deep-sea fish.

Otoliths are paired calcium carbonate structures found within the semicircular canals of all teleost fish, where they assist in balance and/or hearing. There are typically three pairs of otoliths per fish, the largest and most commonly utilized is the sagittal pair. Two main attributes make them useful as recorders of fish habitats conditions. First, calcium carbonate is routinely and regularly deposited onto the otolith. The regularity of otolith deposition, as well as its inability to be reworked or resorbed (Campana, 1999), 
accounts for the annuli (rings) that are commonly used for age determination within fish (Campana and Nielsen, 1985; Jones, 1986). Second, the composition of the accreted otolith reflects the fluid chemistry of the fish's habitat. Stable isotopes and trace elements within the fish's environment are also regularly incorporated into the otolith. The ability of otoliths to incorporate these isotopes and trace metals in a relatively predictable manner has lead to an area of research dedicated to examining otolith chemistry in order to reconstruct the physical and chemical environments experienced by fish throughout their lifetime, and has proven most useful for fish that utilize chemically distinct water masses (Elsdon and Gillanders, 2002; Brazner et al., 2004).

In principle, environmental water chemistry should be correlated with otolith chemistry, but in reality the incorporation of elements into the otolith and the interpretation of the resulting otolith chemistry are less straightforward. Elements that are less sensitive to physiological regulation are better candidates for otolith studies, and the uptake and deposition of trace elements including strontium (Sr), barium (Ba), manganese $(\mathrm{Mn})$, zinc $(\mathrm{Zn})$, lead $(\mathrm{Pb})$, iron $(\mathrm{Fe})$, lithium $(\mathrm{Li})$, cadmium $(\mathrm{Cd})$ and nickel (Ni) appear to be regulated more by environmental availability than biological activity (Campana, 1999). Ba, Sr, and Mn otolith concentrations in particular appear to be dictated more by habitat water chemistry than environmental or physiological factors such as salinity or fish growth rates (Martin \& Thorrold, 2005; Walther \& Thorrold, 2006); though the linkages between fish environment and otolith composition are complex and not fully understood. 
Venting environments, in contrast to the surrounding deep-sea, have highly variable fluid chemical composition and flux that can influence the peripheral habitats. Though fluid chemistry varies both temporally and spatially, a number of elements often considered in otolith studies ( $\mathrm{Sr}, \mathrm{Ba}, \mathrm{Mn}$ ) are typically enriched in hydrothermal fluids relative to non-vent seawater values (Table 1). Fish associated with these chemosynthetic habitats may incorporate hydrothermally enriched concentrations of elements into their otoliths, making otoliths a useful tool for gaining insights into vent fish life history and interaction with venting habitats during their lifespan. Due to the high variability in vent fluid flow over short temporal and spatial scales at hydrothermally active areas, it is likely that only broad scale patterns may be visible within the otolith. Finer-scale observations, on the level of individual vent sites and local temporal variability, may be too ephemeral or short-lived to be resolved within the otolith. However, it may be possible to distinguish between fish that utilize different micro-habitats within the same vent field. Given that Thermarces cerberus is known to live directly within diffuse flow, while Thermichthys hollisi tends to inhabit areas less directly influenced by hydrothermal flow, the chemical composition of T. hollisi otoliths could be expected to exhibit elemental values intermediate to those of $T$. cerberus and a "typical" deep-sea fish. 


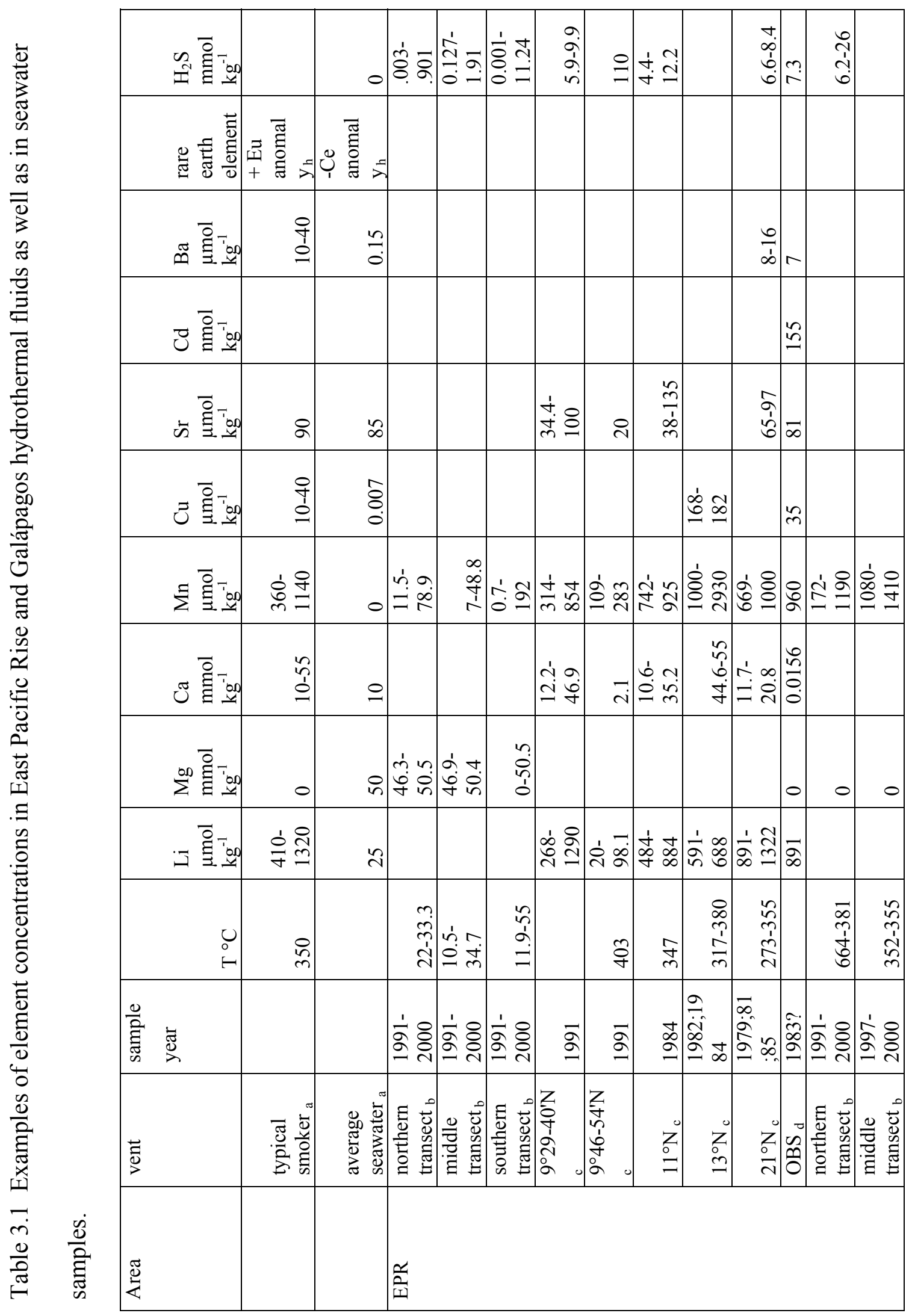




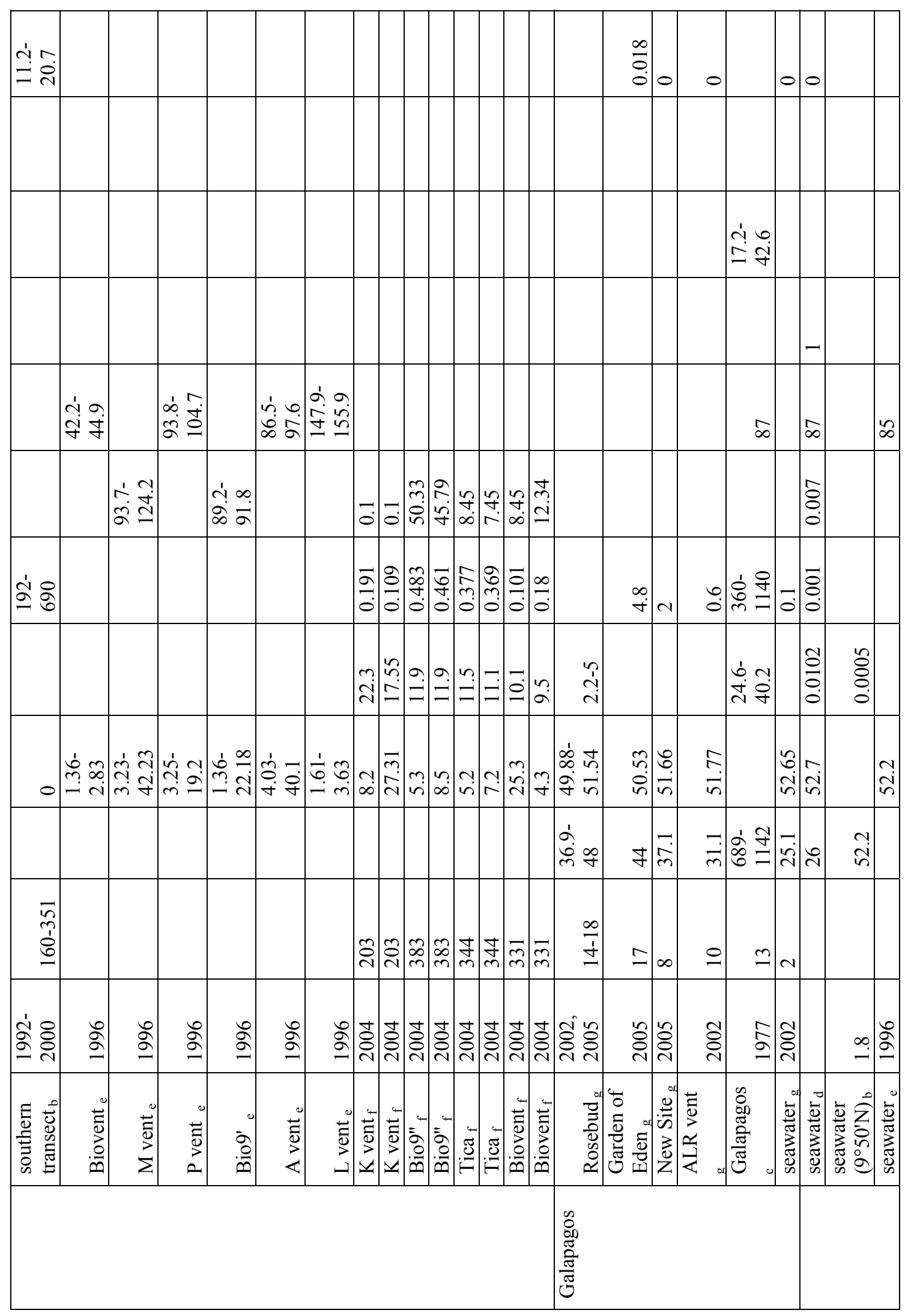




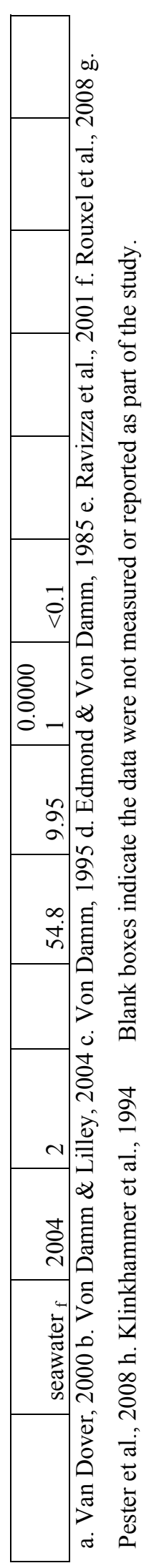


The goal of this study is to explore (chemical) habitat preferences over the lifespan of vent-endemic fish by using otolith chemical composition in order to elucidate habitat usage and life history of the organisms. Initially we examine the limitations and assumptions of otolith isotope studies in the application to variable environments (in this case vents). In other words, is this technique sensitive enough to detect variability within the venting environment and are there differences between vent and non-vent fish? We then examine Thermichthys hollisi and Thermarces cerberus life history strategies through the chemical analysis of the otolith over the fishes' life span.

Hypotheses:

- Hydrothermal fluid exposure will be reflected within the otoliths of vent fish as an increased concentration of hydrothermally enriched elements in comparison to non-vent fish.

- Thermarces cerberus, due to its habitat preference, will exhibit a greater concentration of hydrothermal elements than Thermichthys hollisi.

- Thermichthys hollisi, based on observed sizes of fish associated with vents, does not spend its entire life cycle within the influence of hydrothermal systems. 


\subsection{Methods}

\subsubsection{Otolith processing}

Individuals of Thermichthys hollisi and Thermarces cerberus were collected as described in the previous chapter. The fish were frozen at sea with the otoliths intact inside the fish until processing in the laboratory could occur. Twelve individuals of $T$. hollisi were partially defrosted in warm water, the top portion of the head removed, and both sagittal otoliths (hereafter otolith will only be referring to the processed sagittae) were removed from each individual (Figure 3.1). The otolith pairs were rinsed in Milli-Q water and left to dry overnight. T. hollisi otoliths (one per individual) were mounted in wax and horizontally sectioned on a Buehler Isomet low speed diamond-blade saw with three spacers. The resulting $\sim 24 \mu \mathrm{m}$ wide thick section was mounted on a slide using superglue. The otoliths were polished using decreasing grit lapping paper (240 grit, 30 micron and 3 micron) until it was clear the core had been reached (Figure 3.2). Each otolith was then soaked in Milli-Q water until it lifted off of the slide, flipped, mounted in glue, and polished on the opposite side to achieve as thin a section as possible without compromising the structure of the otolith. Non-vent, deep-sea fish otoliths (2 individuals of Coryphaenoides acrolepis; 1 individual of Lycodes diapterus; and 1 individual of Nezumia stelgidopelis from the Pacific slope) were kindly provided by W. Wakefield and V. Simon (NOAA Fisheries, NWFSC). A double sagittal grind was performed on the non-vent and $T$. cerberus otoliths, without prior sectioning, as otolith structure was readily visible under these conditions. Under class 100 clean room conditions the polished otoliths were cleaned by rinsing with ultra-pure 5\% nitric acid, and sonicating 
for five minutes in ultra-pure Milli-Q water, and then triple rinsing with ultra-pure water. The otoliths were allowed to dry for a minimum of one hour in a laminar flow hood and were mounted onto a clean slide (eight otoliths per slide) using double-sided sticky tape and stored until analysis on the mass spectrometer.

\subsubsection{ICPMS Analysis}

The chemical composition of the otoliths was analyzed on a ThermoFinningan Element 2 single collector inductively-coupled plasma mass spectrometer linked to a New Wave Research UP213 deep-UV YAG laser ablation system. The laser software was utilized to ablate a raster in the core of each otolith using a $70 \mathrm{um}$ width $5 \mathrm{~Hz}$ laser beam at $70 \%$ power. Each otolith was subsequently ablated in 100 um width lines sequentially aligned from the edge of the core to the edge of the otolith. Ablation lines were designed to follow the arrangement of otolith deposition rings as well as possible (Figure 3.3). A suite of elements $\left({ }^{7} \mathrm{Li},{ }^{25} \mathrm{Mg},{ }^{48} \mathrm{Ca},{ }^{55} \mathrm{Mn},{ }^{63} \mathrm{Cu},{ }^{88} \mathrm{Sr},{ }^{114} \mathrm{Cd},{ }^{138} \mathrm{Ba},{ }^{139} \mathrm{La},{ }^{140} \mathrm{Ce},{ }^{142} \mathrm{Nd}\right.$, ${ }^{152} \mathrm{Sm},{ }^{153} \mathrm{Eu},{ }^{158} \mathrm{Gd}$, and ${ }^{208} \mathrm{~Pb}$ ) were measured at low resolution utilizing a $5 \%$ mass window. Blank and standard solutions (40ppm FEBS-1 - Sturgeon et al., 2005 and NIES-022 - Yoshinaga et al., 2000) were run at regular intervals between ablations lines. Data were reported as mean intensity averages. Blank values were linearly interpolated between blank measurements and subtracted from the raw intensity averages to remove background interference. Instrument mass bias was corrected for by standardizing the values to a reference solution (FEBS-1) as per the method outlined in Rosenthal et al. (1999). The Ba:Ca correction factor was used to correct the rare earth elements. 
Detection limits were calculated as 3 times the standard deviation of the mean of the blank solutions and are reported as a percentage of the average sample intensity. They are as follows: $\mathrm{Li} 14.08, \mathrm{Mg} 5.94, \mathrm{Ca} 0.05, \mathrm{Mn} 48.17, \mathrm{Cu} 65.85, \mathrm{Sr} 0.02, \mathrm{Cd} 46.5, \mathrm{Ba}$ 0.23, La 31.42, Ce 31.1, Nd 67.57, Sm 33.73, Eu 31.81, Gd 51.52, Pb 62.25. Relative standard deviations, a measure of external precision were as follows: $\mathrm{Li} 2.56, \mathrm{Mg} 5.09$, Mn 43.3, Cu 66.79, Sr 0.64, Cd 26.66, Ba 1.18, La 42.97, Ce 54.17, Nd 111.8, Sm 25.34, Eu 23.59, Gd 114.37, $\mathrm{Pb}$ 55.18. Core versus non-core values were compared among groups and statistical analyses were performed using Systat ver. 10.

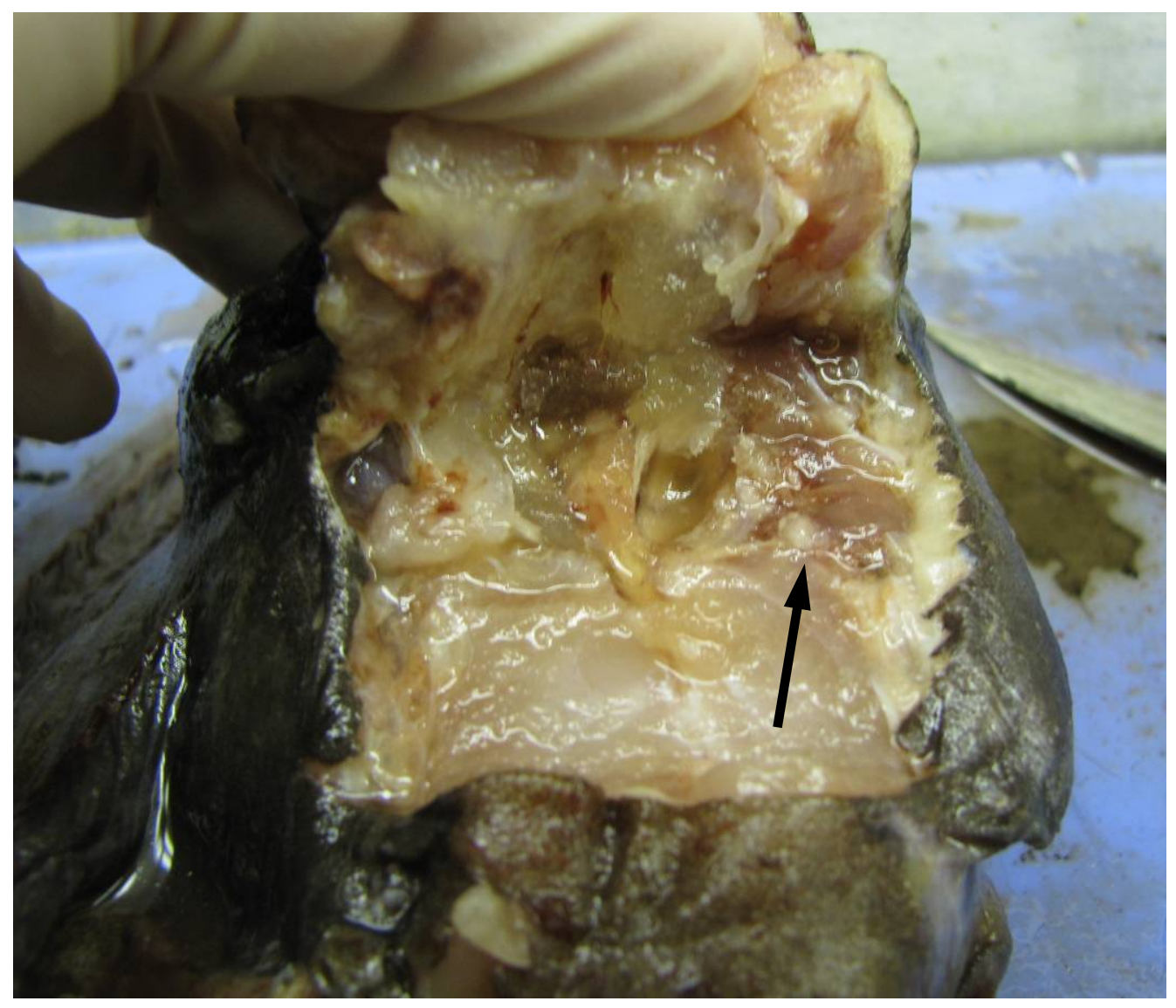

Figure 3.1 Cranial cavity of Thermichthys hollisi. The arrow points to a sagittal otolith. 


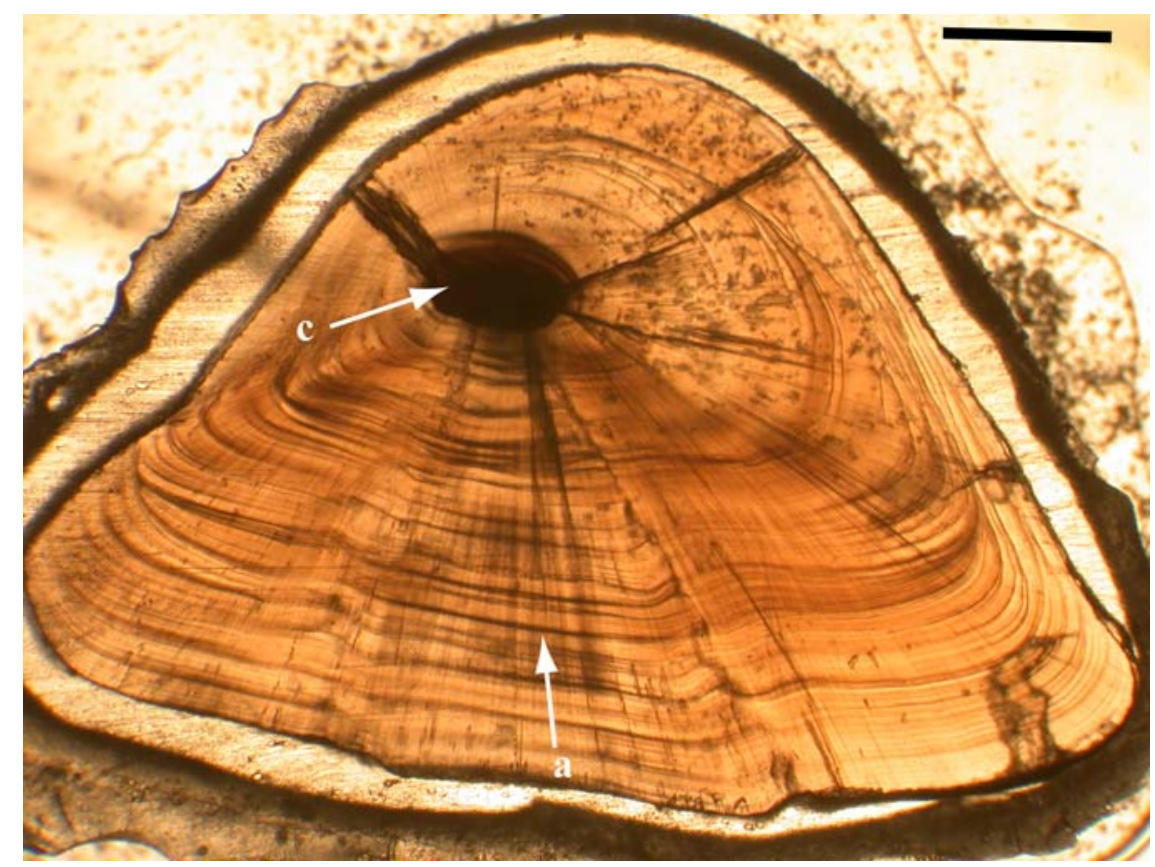

Figure 3.2 Example of a polished Thermichthys hollisi otolith, exhibiting clear structure of the core (c) and annuli (a). Scale bar is approximately $1 \mathrm{~mm}$.

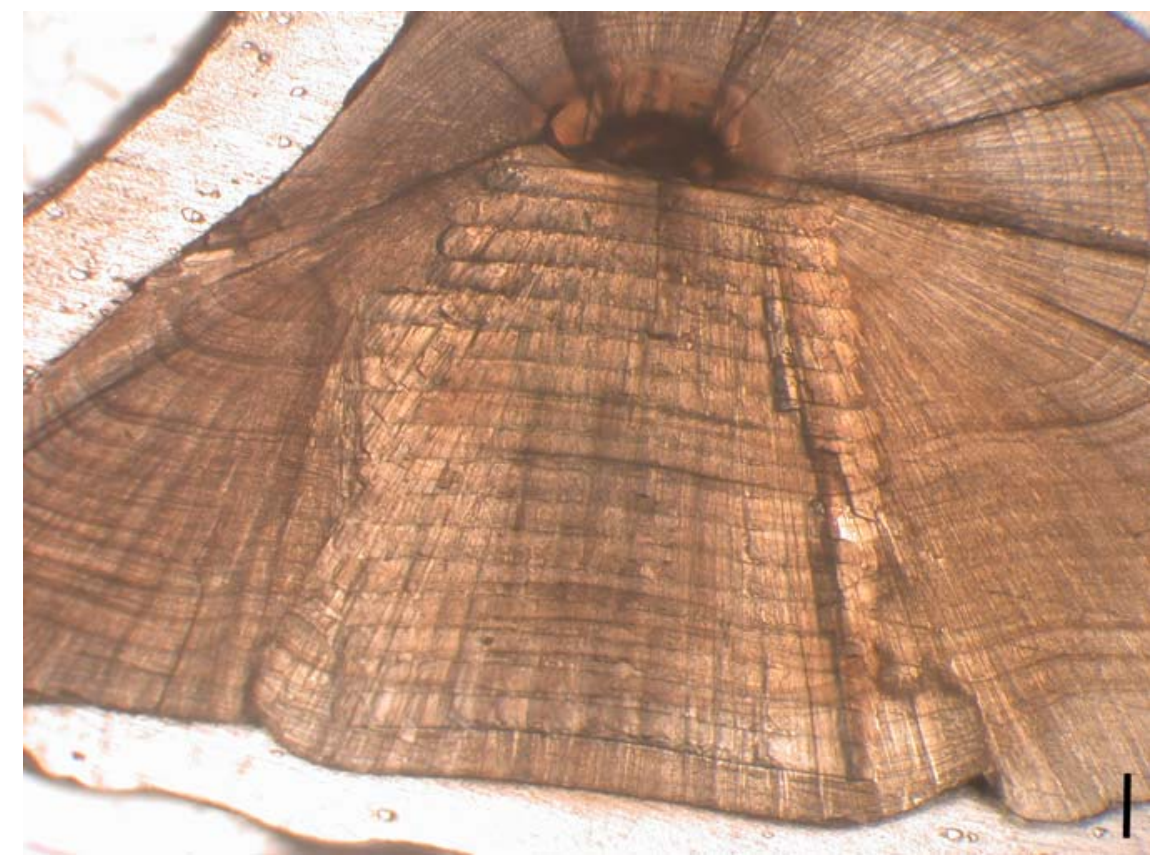

Figure 3.3 Ablated section of Thermichthys hollisi otolith. Scale bar is $200 \mu \mathrm{m}$. 


\subsection{Results}

In total 12 individuals of Thermichthys hollisi, two individuals of Thermarces cerberus, and four unrelated non-vent fish were analyzed; hereafter referred to as "bythitid", "zoarcid", and "non-vent" respectively. $\mathrm{Li}, \mathrm{Mg}, \mathrm{Sr}$, and Ba measurements were above detection limits for $100 \%$ of the samples taken from all fish (Figure 3.4). Bythitid Li:Ca ranged from 1.700 to $11.700 \mu \mathrm{mol}^{\mathrm{mol}}{ }^{-1}$ with a mean lifetime average of $3.406 \mu \mathrm{mol}^{\mathrm{mol}}{ }^{-1}$, while zoarcid measurements ranged from 6.037 to $9.645 \mu \mathrm{mol}^{\mathrm{mol}}{ }^{-1}$ with a mean lifetime average of $6.805 \mu \mathrm{mol}_{\mathrm{mol}}{ }^{-1}$, and non-vent fish Li:Ca ranged from 4.965 to $15.501 \mu \mathrm{mol}^{\mathrm{mol}}{ }^{-1}$ with a mean lifetime average of $10.005 \mu$ mol.mol ${ }^{-1}$. Mg:Ca levels ranged from 3.101 to $144.615 \mu$ mol.mol $^{-1}$ (mean 11.372) for bythitids, 9.313 to $30.466 \mu \mathrm{mol}^{\mathrm{mol}}{ }^{-1}$ (mean 13.056) for zoarcids, and 24.527 to $158.180 \mu \mathrm{mol}^{\mathrm{mol}}{ }^{-1}$ (mean 55.623) for non-vent fish. Sr:Ca ranged from 2500.636 to $10488.313 \mu$ mol.mol $^{-1}$ (mean 6496) for bythitids, 4119.770 to $14660.969 \mu \mathrm{mol}^{\mathrm{mol}}{ }^{-1}$ (mean 9999.228) for zoarcids, and 1924.316 to $6364.109 \mu$ mol.mol $^{-1}$ (mean 3443.361) for non-vent fish. Ba:Ca ranged from0.954 to $5.553 \mu \mathrm{mol}^{\mathrm{mol}}{ }^{-1}$ (mean 2.255) for bythitids, 8.134 to $31.012 \mu \mathrm{mol}^{\mathrm{mol}}{ }^{-1}$ (mean 17.563) for zoarcids, and 1.093 to $8.406 \mu \mathrm{mol}^{\mathrm{mol}}{ }^{-1}$ (mean 4.165) for non-vent fish. Between 50 and $90 \%$ of the bythitid measurements (Figure 3.5) were above detection limits for $\mathrm{Cd}: \mathrm{Ca}\left(\right.$ mean $\left.0.004 \mu \mathrm{mol}_{\mathrm{mol}}{ }^{-1}\right), \mathrm{La}: \mathrm{Ca}\left(\right.$ mean $0.001 \mu \mathrm{mol}^{\mathrm{mol}}{ }^{-1}$ ), Ce:Ca (mean $0.001 \mu$ mol.mol ${ }^{-1}$ ), Sm:Ca (mean $0.001 \mu$ mol.mol $^{-1}$ ), and Eu:Ca (mean $0.001 \mu$ mol.mol ${ }^{-1}$ ). For zoarcids, between 50 and $90 \%$ of the measurements (Figure 3.5) were above detection limits for $\mathrm{Cd}$ (mean Cd:Ca $0.006 \mu$ mol.mol $^{-1}$ ), La (mean La:Ca $0.002 \mu \mathrm{mol}_{\mathrm{mol}}{ }^{-1}$ ), and Ce (mean Ce:Ca $0.001 \mu \mathrm{mol}^{\mathrm{mol}}{ }^{-1}$ ); while Sm (mean Sm:Ca 
$0.005 \mu \mathrm{mol} . \mathrm{mol}^{-1}$ ) and Eu (mean Eu:Ca $0.007 \mu \mathrm{mol}^{\mathrm{mol}}{ }^{-1}$ ) were above detection limits for all zoarcid samples. For non-vent fish, Mn (mean Mn:Ca $\left.1.580 \mu \mathrm{mol} . \mathrm{mol}^{-1}\right), \mathrm{Sm}$

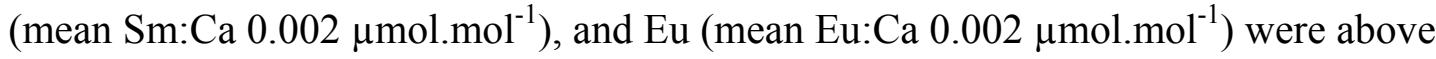
detection limits for between 50 to $90 \%$ of the samples (Figure 3.6).

Otoliths from individual fish within a species group revealed additional patterns. Li:Ca ratios are visibly different between the three groups (Figure 3.7) with zoarcids exhibiting values intermediate to the other two groups. The two zoarcids examined showed similar patterns over their lifetime for most elements, most noticeably strontium (Figure 3.8), cadmium (Figure 3.9), barium (Figure 3.10), and magnesium (Figure 3.11). Manganese (Figure 3.12), copper and lead did not show distinct differences between between groups. Copper and lead measurements were mostly below detection limits and exhibited large RSDs, and thus will not be considered further. With the exception of $\mathrm{Sm}: \mathrm{Ca}$ and $\mathrm{Eu}: \mathrm{Ca}$, most non-vent fish rare earth measurements were below detection limits, while for the bythitids and zoarcids only $\mathrm{Nd}: \mathrm{Ca}$ and $\mathrm{Gd}: \mathrm{Ca}$ were below detection limits for the majority of the samples. For both $\mathrm{Sm}: \mathrm{Ca}$ and Eu:Ca, zoarcids exhibited the highest ratios and bythitids the lowest, with differences between all groups (Figure 3.13). The values within the core of bythitid otoliths are noticeably elevated for multiple elements. A comparison of mean core values between groups using a one way ANOVA with a Bonferroni post-hoc test (significance level 0.05) applied indicated that bythitid core values for barium are indistinguishable from that of non-vent fish, but are significantly different from core values of zoarcids. However, mean barium values for all non-core measurements differed significantly between all groups. Similarly, Li:Ca and 
Sr:Ca core bythitid values are similar to that of non-vent fish, but significantly different from zoarcids (zoarcids also differ from non-vent), whereas there are differences between all groups for non-core values. For Mg:Ca, bythitid core values did not differ from those of zoarcid or non-vent, but zoarcids were significantly different from non-vent. For noncore Mg:Ca values, bythitids were not able to be distinguished from zoarcids, but both zoarcids and bythitids differed from non-vent. Repeated-measures ANOVA indicated a significant (multivariate Wilks' Lambda significance level $p<0.05$ ) increase in strontium across the span of the entire otolith for bythitids, but other than the distinct core signatures, there are no significant cross-otolith patterns for $\mathrm{Li}, \mathrm{Mg}$, or $\mathrm{Ba}$. 

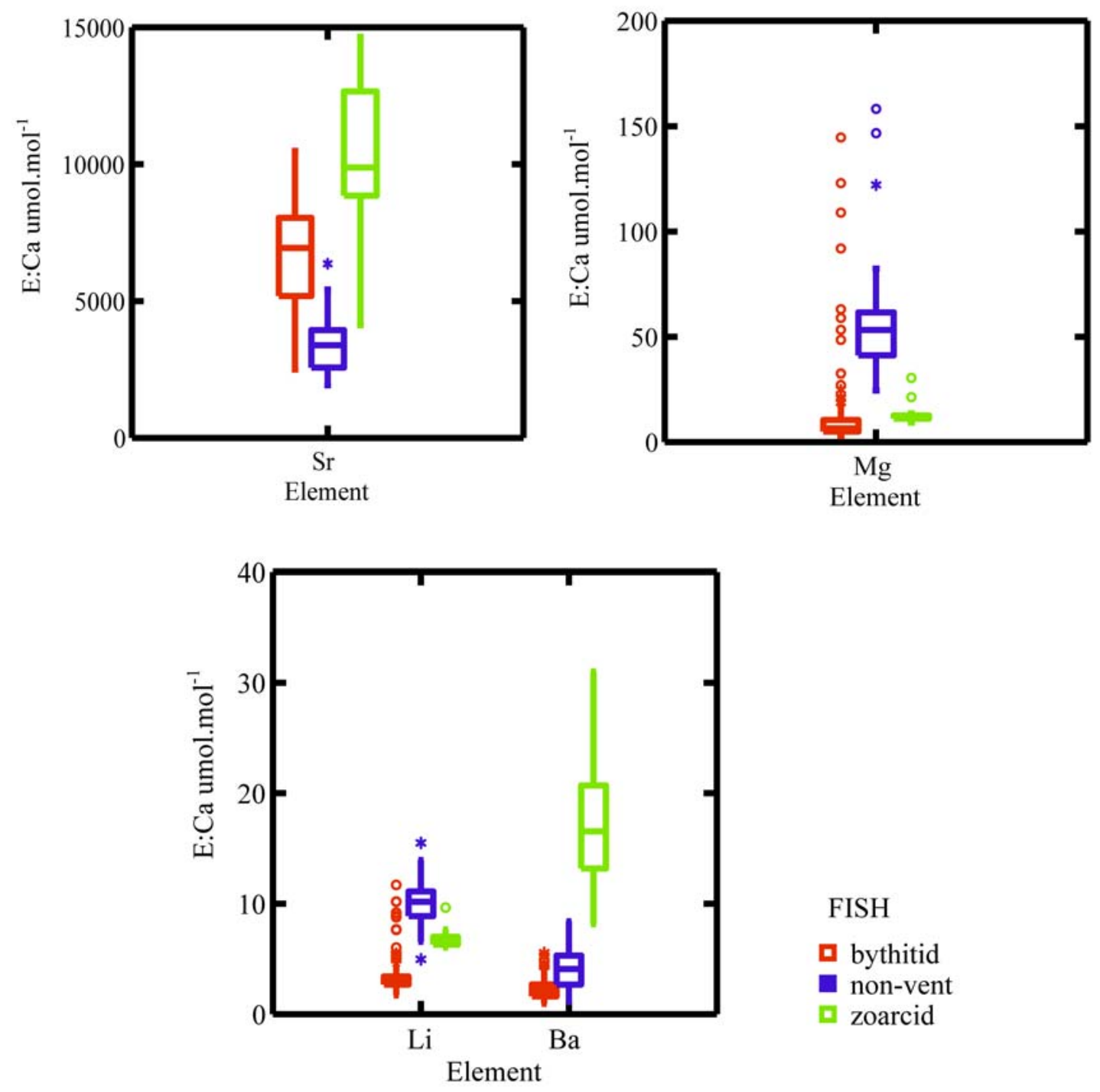

Figure 3.4 Box plot of elements found in 100\% of samples taken ( $\mathrm{Li}, \mathrm{Ba}, \mathrm{Sr}$, and $\mathrm{Mg}$ ), indicating the median and range of values observed. The box indicates the range incorporating $50 \%$ of the values. Asterisks indicate values in between the inner and outer fence and open circles represent far outside values. 


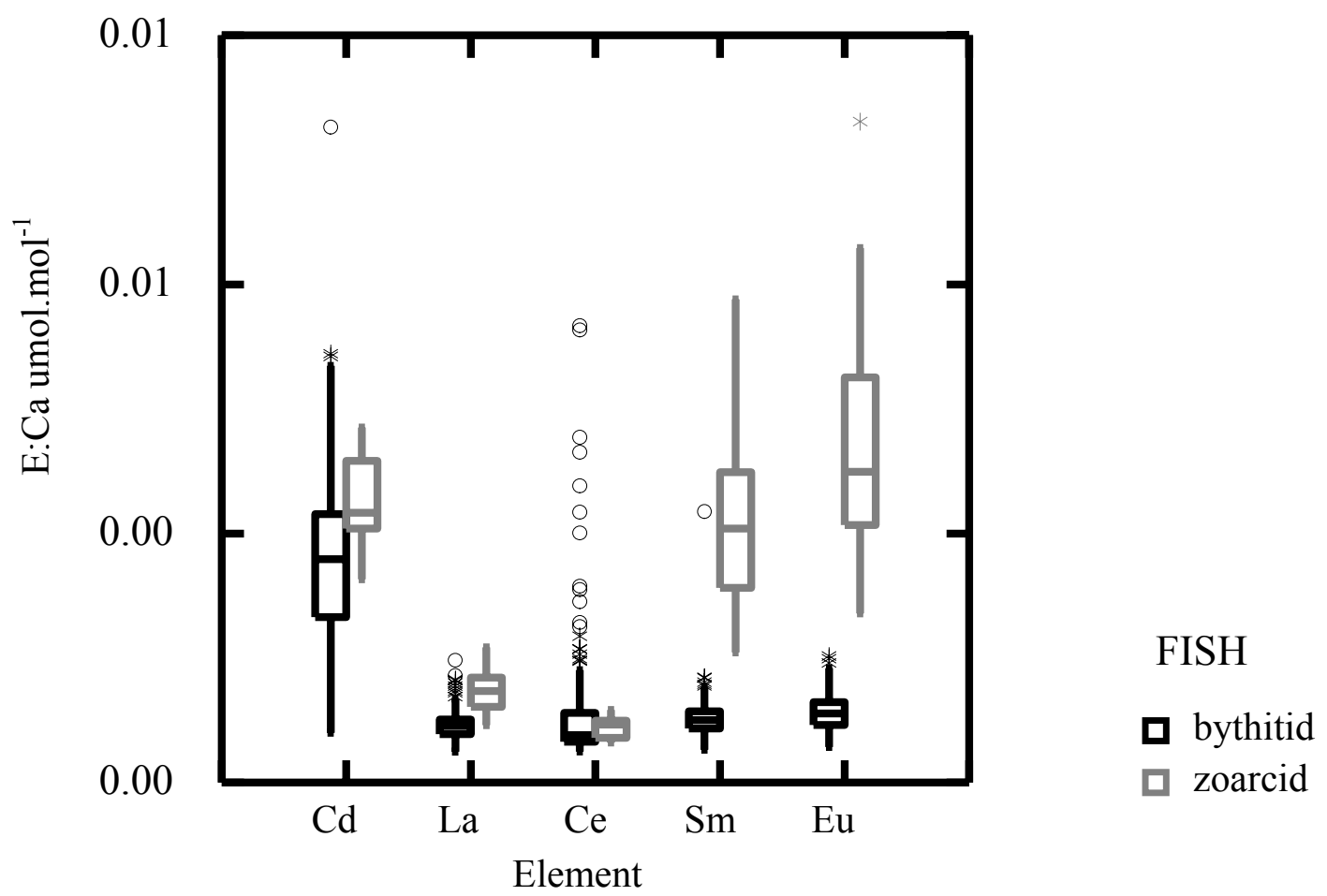

Figure 3.5 Median and range of values for elements present in 50-90\% of bythitid and zoarcid samples. 


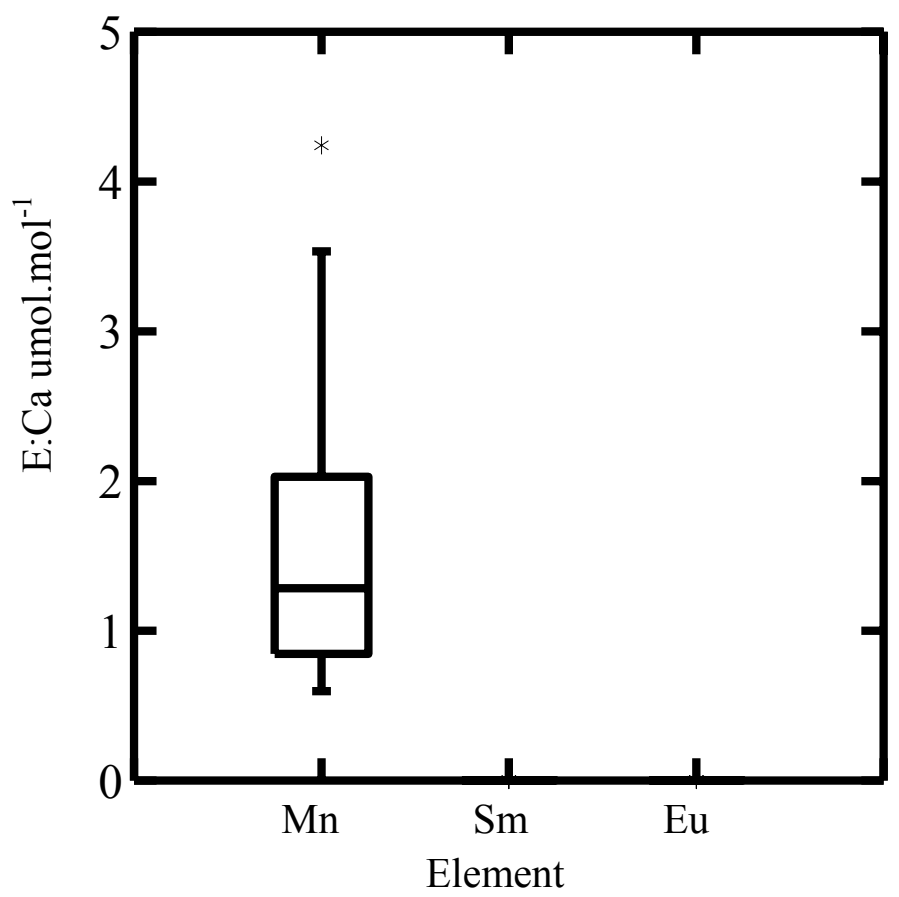

Figure 3.6 Median and range of elements present in 50-90\% of non-vent otolith samples.

Values for Sm:Ca and Eu:Ca are not zero but are less than 0.005 umol mol$^{-1}$. 


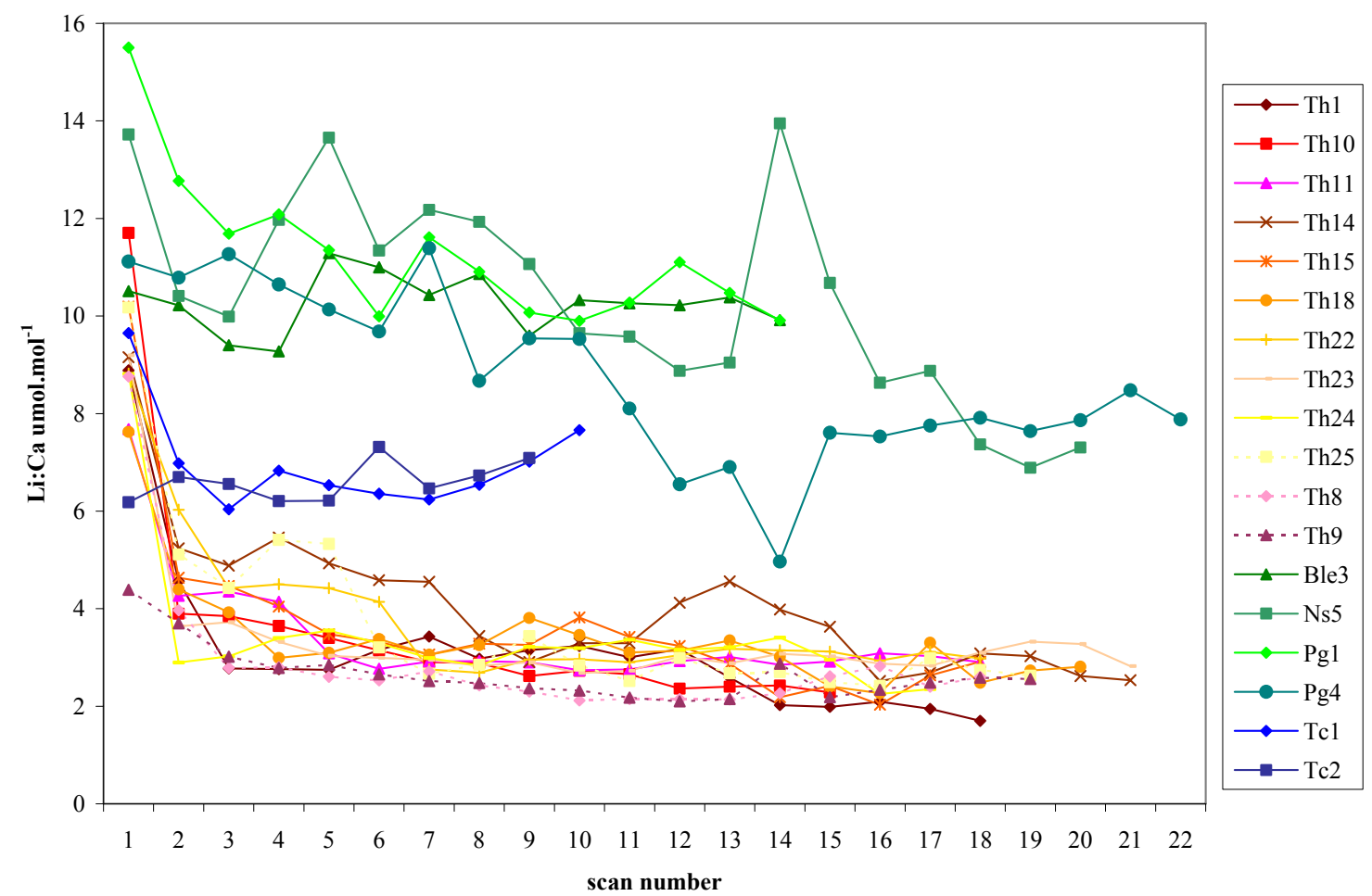

Figure 3.7 Li:Ca measurements of all otoliths. For this and all further graphs the core is represented by scan 1 with increasing scan numbers from the core to the edge of the otolith reflecting the increasing age of the fish. Any values below detection limits are graphed as "0". "Th" designates Thermichthys hollisi, "Tc" designates Thermarces cerberus, "Ble" is black eelpout, "Pg" is Pacific grenadier, and "Ns" designates Nezumia stelgidopelis. For Li:Ca, non-vent fish have the highest $\mathrm{Li}: \mathrm{Ca}$ levels, bythitids lowest and zoarcids intermediate. Bythitid otolith core measurements are elevated to similar levels as exhibited by the non-vent fish analyzed. 


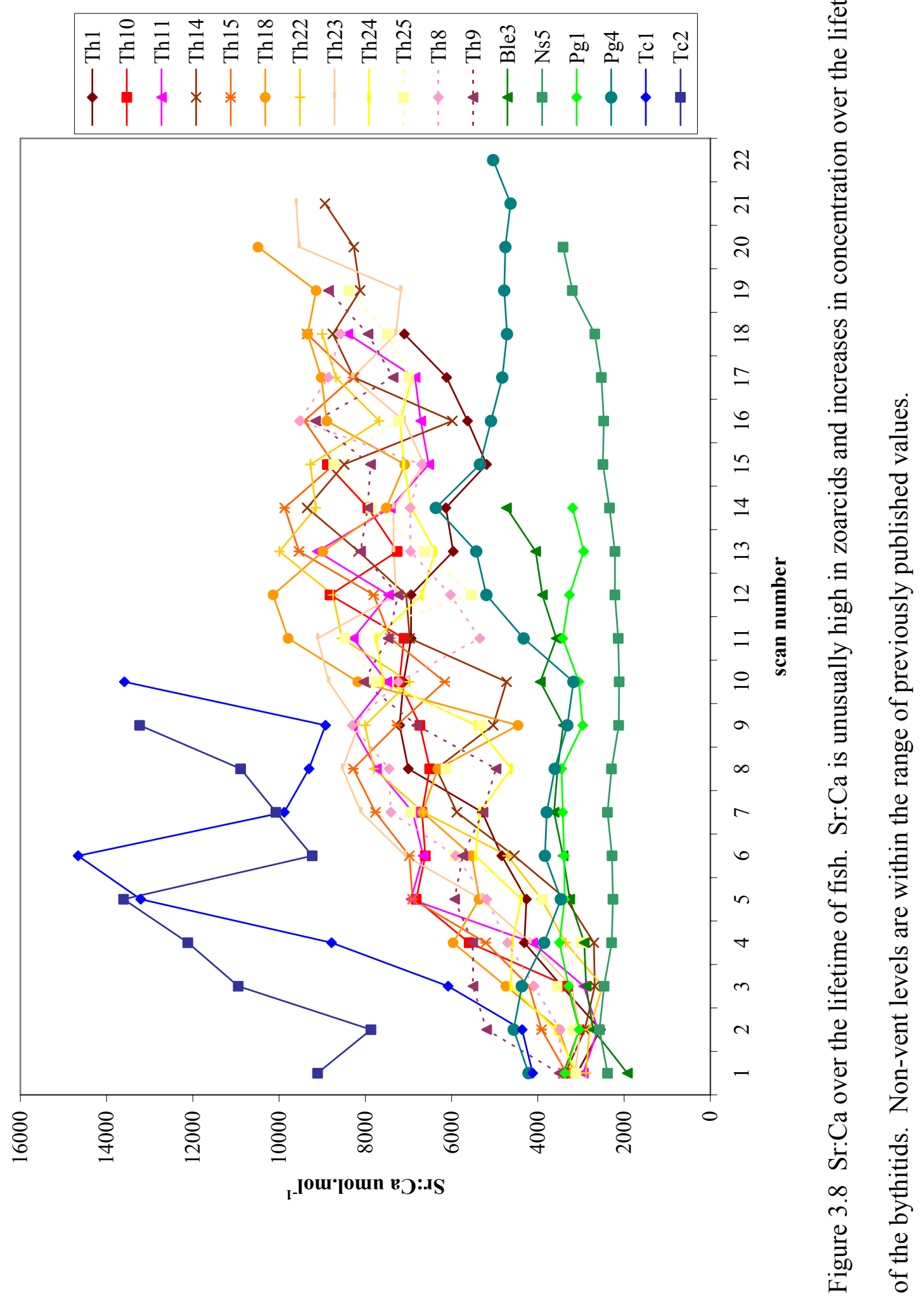




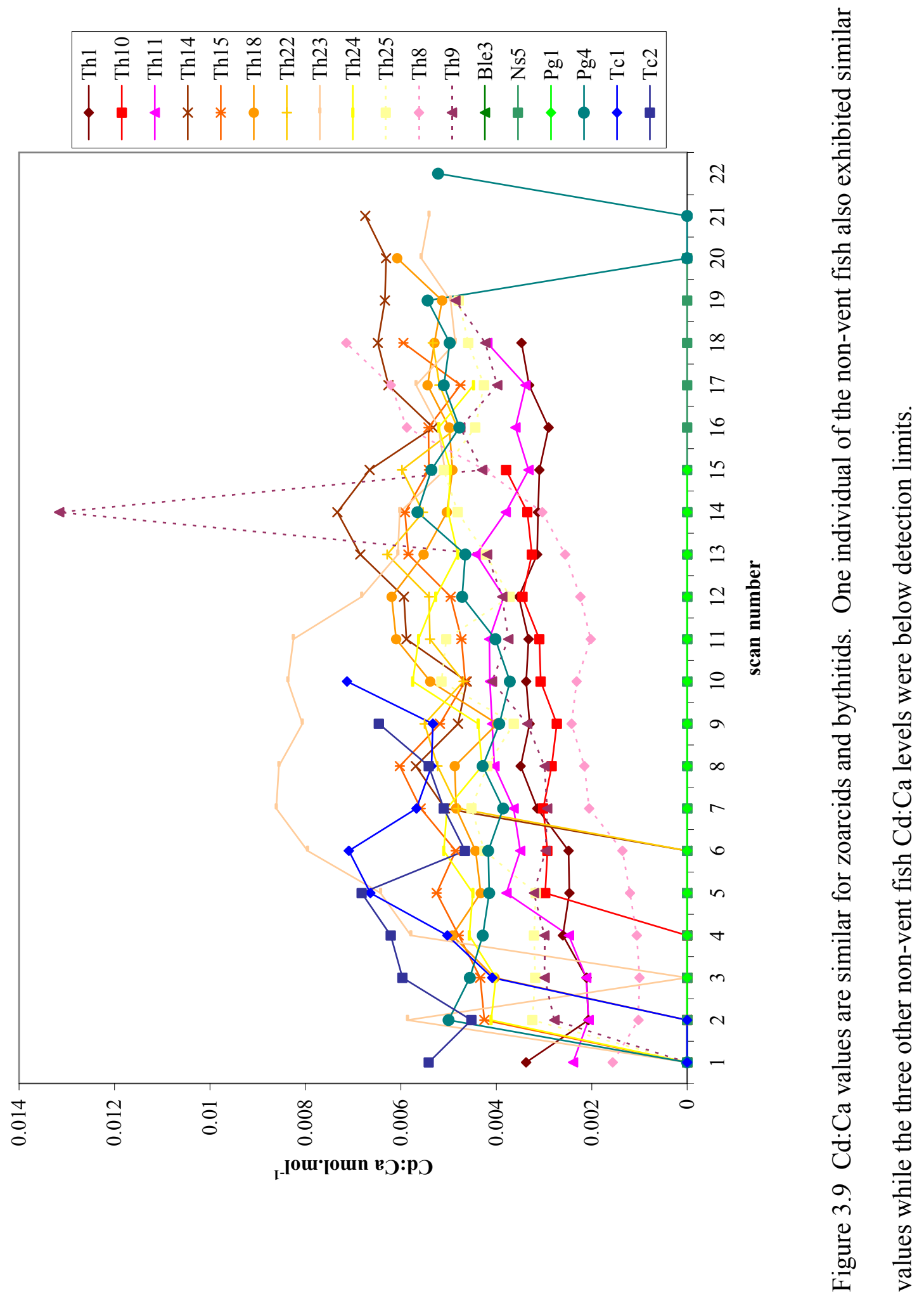




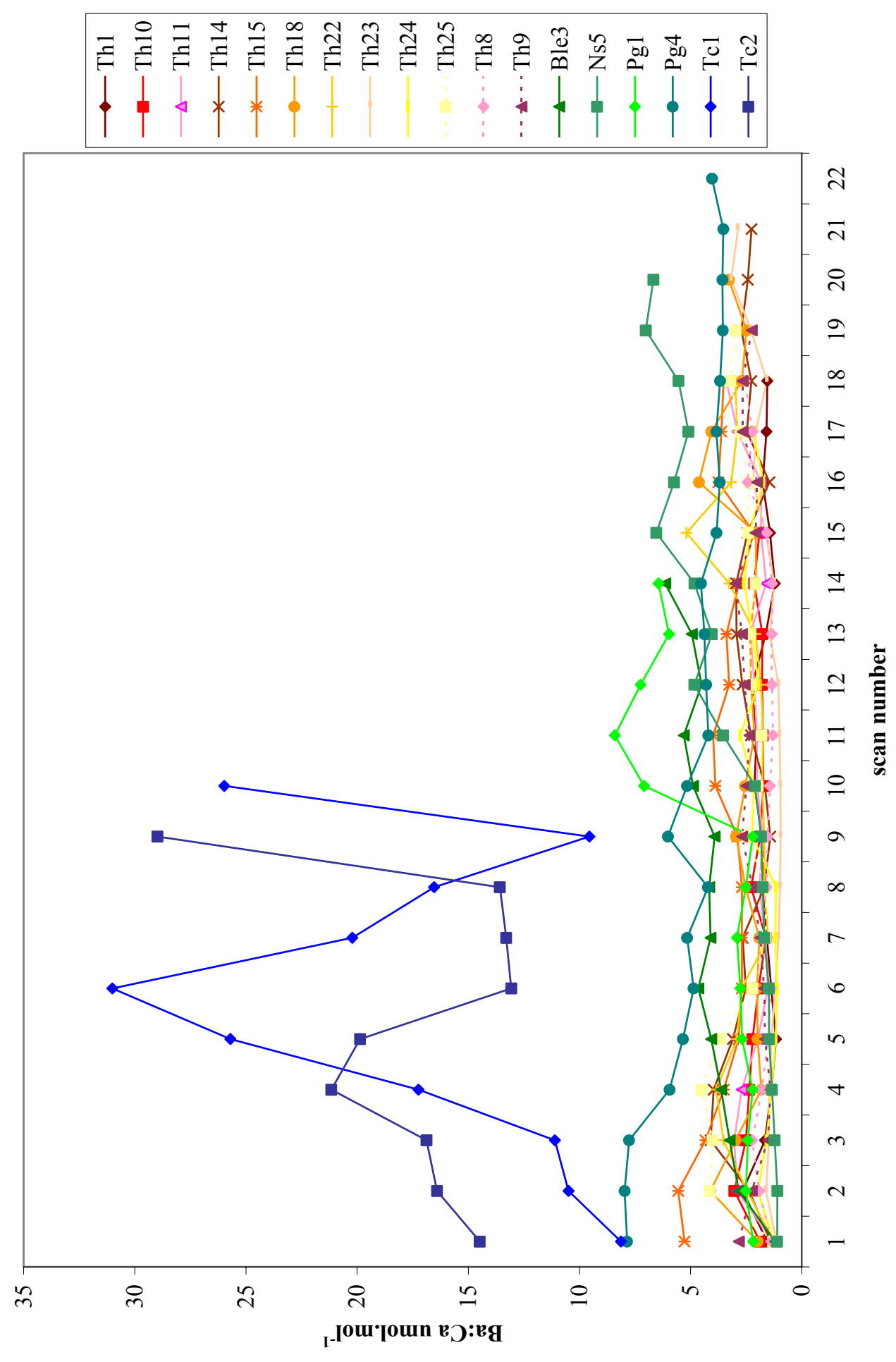

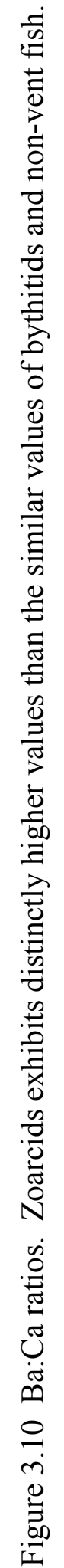




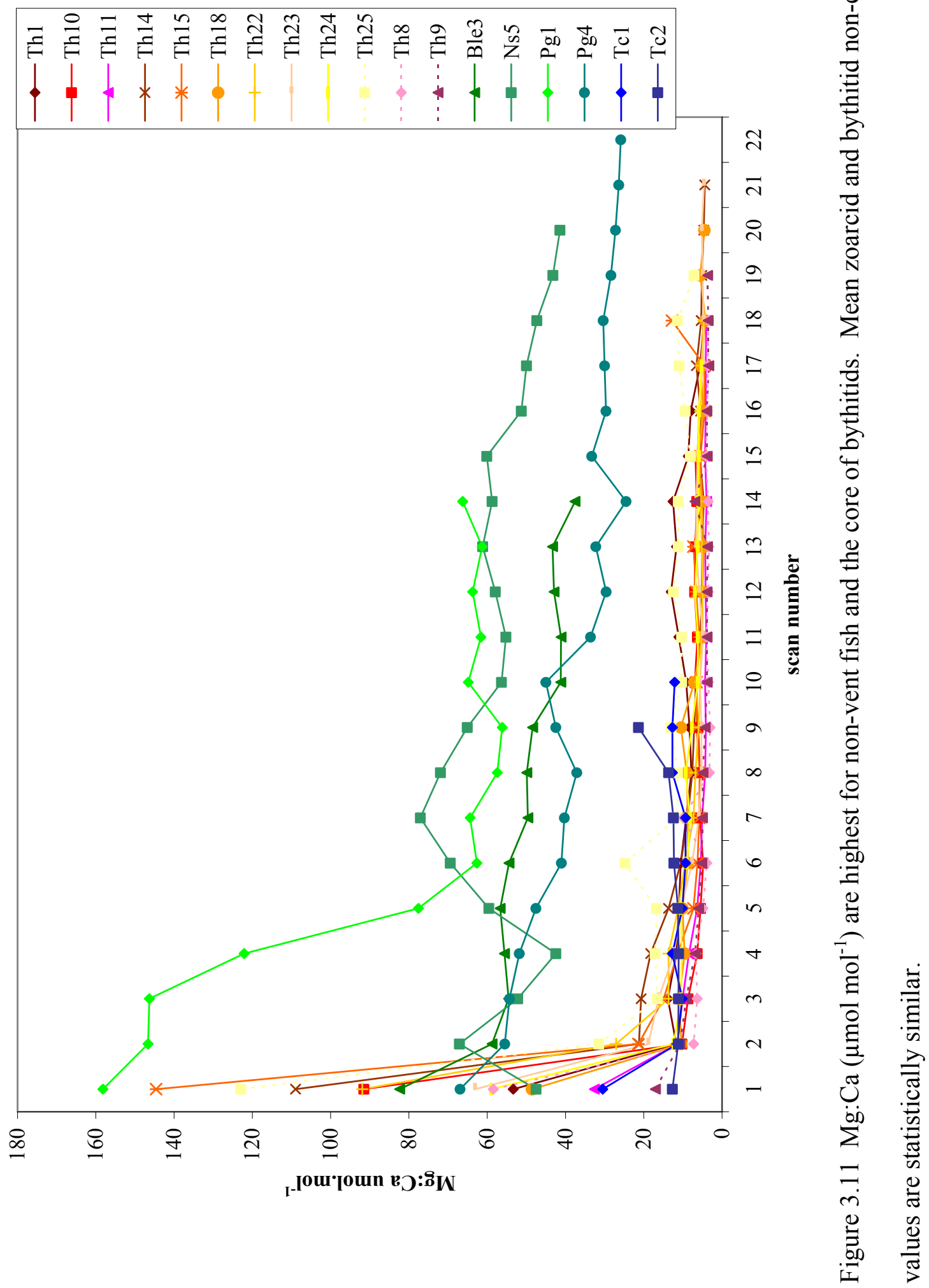




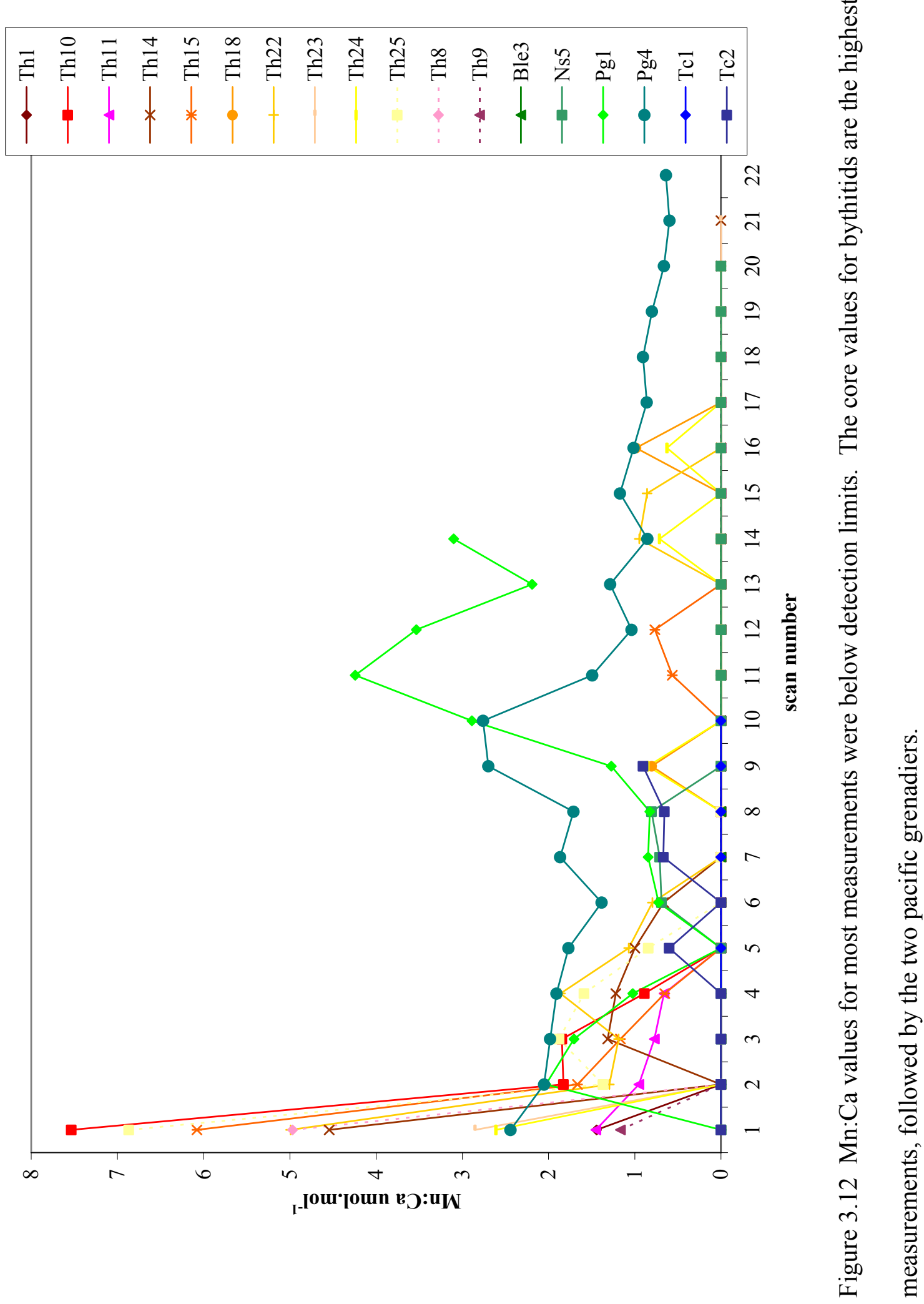




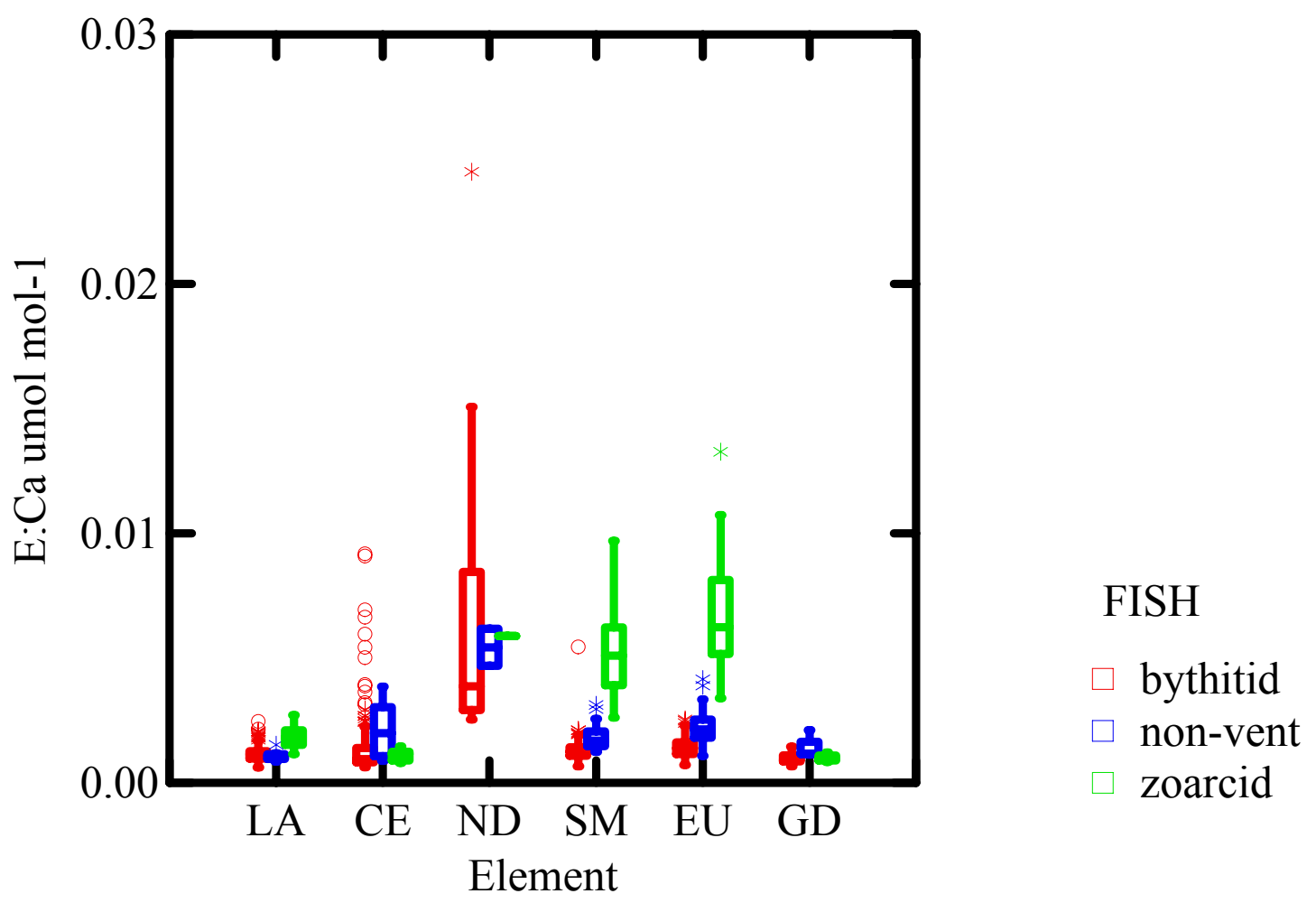

Figure 3.13 Median and range of rare earth elements for all measurements above detection limits. There are significant differences among all groups for Sm:Ca and Eu:Ca. 


\subsection{Discussion}

Numerous studies have indicated the utility of otoliths to impart information regarding the habitat characteristics of fish species. Alkaline and alkaline earth elements ( $\mathrm{Sr}, \mathrm{Li}, \mathrm{Ba}, \mathrm{Mg}$ ) have received the most attention as they are present in higher concentrations than trace metals such as cadmium, copper, or lead, and are not subject to the same physiological regulation as other metabolically active elements (Campana, 1999). Though there is inherently some regulation of element concentrations as they are passed from seawater to blood plasma to endolymph to otolith, and factors such as salinity, temperature, or element interactions may affect element uptake and incorporation, there is still a useful (though not perfect) correlation between the environmental habitat chemistry and elements recorded within the otolith. To date, no studies have explored otolith chemistry within venting environments, where the unique fluid chemistry may provide insights into both fish life history, and how the elements are incorporated into the otolith. Though the vent fish examined live within lower temperature $\left(<30^{\circ} \mathrm{C}\right)$ diffuse flow areas where seawater has mixed with the hydrothermal fluid, the habitat chemistry is still measurably different from that of ambient temperature, non vent-influenced areas (Table 3.1).

It was hypothesized that elements elevated within hydrothermal fluids (Mn, Sr, Cd) would show similar elevation within vent fish otoliths in comparison to typical otolith concentrations; and that the two species of vent fish examined may indicate different patterns due to their different microhabitat preferences. As we have only observed one size class of the bythitid Thermichthys hollisi at the vents, it was also 
hypothesized that this species of fish may be spending part of its life cycle away from the vent systems, and that this migration would be detectable within the otolith. The results of this study indicated that the chemical composition of the hydrothermal fluids is influencing the otolith chemical composition of vent fish, and that the degree of influence may be dependent upon fish preferred habitat.

When hydrothermal fluids interact with seawater, most of the enriched metals precipitate as metal sulfides. This can take the form of black "smoke" and sulfide chimneys in the case of high temperature, focused flow areas. In diffuse flow areas, most of the entrainment of seawater happens subsurface, and the chemically-reduce fluid emerging is depleted relative to end member fluids. Diffuse flow environments also tend to be both spatially and temporally variable, across a spectrum of scales. Despite these caveats, the diffuse flow environments where both species of vent fish are found contain detectable differences in temperature, oxygen, sulfide, and metal concentrations from ambient seawater. These differences appear to be reflected within the otoliths, and may even be indicative of habitat preferences between the two vent fish. This is most readily evident within the Mg:Ca measurements. End-member hydrothermal fluids are considered to have a magnesium concentration of zero (Edmond et al., 1979). In diffuse fluid environments where the fish are found, magnesium concentration is greater than zero, but still lower (typically $<50 \mathrm{mmol} \mathrm{kg}^{-1}$ ) than what is found in unaltered bottom water (Von Damm \& Lilley, 2004). This is reflected within the vent fish otoliths, which show lower values than those of the non-vent fish analyzed. In comparison to other biogenic carbonates, the Mg:Ca values in this study are relatively low. Campana (1999) 
list marine fish otoliths as having a mean $\mathrm{Mg}$ :Ca ratios of approximately $117 \mu \mathrm{mol} \mathrm{mol}^{-1}$, while most values in the present study are below $100 \mu \mathrm{mol} \mathrm{mol}^{-1}$. Mollusc shells and corals tend to have even higher $\mathrm{Mg}$ :Ca, often above $1 \mathrm{mmol} \mathrm{mol}^{-1}$ (Carré et al., 2006; Shirai et al., 2008) with the calcitic portion of a deep-sea oyster shell reaching values of $22.5 \mathrm{mmol} \mathrm{mol}^{-1}$ (Wisshak et al., 2009); although Rio et al. (1992) found the shells of the hydrothermal vent bivalves Calyptogena magnifica and Bathymodiolus thermophilus to be depleted in Mg in comparison with littoral mollusc shells. The lower (typically $<40$ $\left.\mu \mathrm{mol} \mathrm{mol}{ }^{-1}\right) \mathrm{Mg}: \mathrm{Ca}$ values of the vent fish otoliths examined are most plausibly due to lowered $\mathrm{Mg}$ content of hydrothermal fluids within their environment.

Zoarcids and bythitids show greater mean levels of strontium, an element that is variable, but can be enriched in vent fluids relative to seawater, than do non-vent fish. The zoarcid values are higher than those of the bythitid, perhaps reflecting their greater environmental exposure to $\mathrm{Sr}$ or the higher temperatures found within their habitat. Both vent fish Sr:Ca values are remarkably high in comparison to values from other biogenic aragonites. For example, Chesapeake Bay spotted seatrout otolith Sr:Ca ranged from 1970-2070 $\mu \mathrm{mol} \mathrm{mol}^{-1}$ (Dorval et al., 2007), shells from Chione subrugosa had values as high as $3600 \mu \mathrm{mol} \mathrm{mol}^{-1}$ (Carré et al., 2006) and Acropora nobilis coral skeletons were even higher, ranging up to $9500 \mu \mathrm{mol} \mathrm{mol}^{-1}$ (Shirai et al., 2008), yet the zoarcid values are still substantially higher. Sr:Ca incorporation can be influenced not only by the $\mathrm{Sr}: \mathrm{Ca}$ concentration of the organisms environment, but also by environmental temperature (Bath et al., 2000; Elsdon and Gillanders, 2002; Richardson et al., 2004) and, at least for molluscs, growth rate (Stecher et al., 1996; Carré et al., 2006). Contrary to the results in 
the present study, Rio et al. (1992) found hydrothermal vent bivalve shells to be depleted in $\mathrm{Sr}$ relative to shallow water shells. While the elvated strontium concentration within hydrothermal fluids (in 1996 fluid samples, L vent had the highest Sr concentrations (Ravizza et al., 2001)) may contribute to the unusually high vent fish Sr:Ca values, the influence of other aspects such as temperature may be equally important; and the combination of factors leading to the high Sr:Ca ratios in vent fish otoliths is not resolved.

Like strontium, barium is highest (with a wide range of values) in zoarcids, yet bythitid otoliths are relatively depleted (with a narrow window of values). Bythitid values are close to the mean marine Ba:Ca otolith ratio $\left(2.84 \mu \mathrm{mol} \mathrm{mol}^{-1}\right)$ proposed by Campana (1999), but other otolith and mollusc shell Ba:Ca ratios have been measured within the range encompassed by the zoarcids (Stecher et al., 1996; Swan et al., 2006; Carré et al., 2006; Dorval et al., 2007). Ba:Ca is thought to be influenced by environmental Ba:Ca concentrations (Campana, 1999; Bath et al., 2000), and perhaps by salinity (Martin and Thorrold, 2005); thus the difference between zoarcid and bythitid values may again reflect their different exposure to hydrothermal fluids through habitat preference. It is interesting to note the similarity of the strontium and barium patterns between the two zoarcids. The strikingly similar patterns suggest that (at least for exposure to these two elements) that otolith chemistry may be a good predictor of habitat chemistry and that these two zoarcids have experienced the same conditions throughout their individual lives. If this is indeed the case, one can hypothesize that zoarcids may 
show fidelity to their particular site (e.g. East Wall vs. Bio9) once they have settled and perhaps are living in cohorts, leading to potential genetic structure between vents.

Lithium also exhibits differences between the three groups, with non-vent fish exhibiting the highest values and bythitids the lowest, with zoarcids intermediate. This result was unexpected, as lithium is enriched in end-member hydrothermal fluids. The behavior of lithium during fluid mixing and the range of values within diffuse fluids is not well defined and though lithium has been measured in prior otolith studies, its behavior during incorporation into the otolith is also not well understood. It has been suggested that lithium incorporation into otoliths may be increased when $\mathrm{Li}: \mathrm{Ca}$ environmental ratios are low (Milton and Chenery, 2001), yet the relationship between lithium in the environment and lithium within biogenic aragonite is not clear. As there are distinct differences between the different fish types examined, this element and its behavior and utility as an environmental recorder bears further study.

The remaining elements do not appear as useful in recording exposure to vent fluids, as they are not consistently present in measurable levels within the otolith. The non-vent fish, with the exception of one seemingly anomalous individual, have quite low cadmium values, while those of the bythitids and zoarcids are higher. $\mathrm{Cd}$ :Ca is highest in zoarcids, though the behavior of this element warrants further exploration. Within the bythitids, Cd:Ca values are high when $\mathrm{Mn}$ :Ca values are low and vice-versa. The rare earth elements are in general higher within the vent fish; however, the lack of consistent $\mathrm{Nd}$ and Gd data within this study make it difficult to assess whether they display the Eu 
anomaly that is indicative of rare earth element concentrations in hydrothermal fluids (Klinkhammer et al., 1994).

Of interest to the elucidation of life history strategy of vent fish are the marked differences in the core concentrations of lithium, magnesium, manganese, strontium, and cadmium within the bythitids. $\mathrm{Li}: \mathrm{Ca}, \mathrm{Mg}: \mathrm{Ca}$, and $\mathrm{Mn}: \mathrm{Ca}$ values are all distinctly higher within the core of the bythitid otolith than in the rest of the otolith. $\mathrm{Li}: \mathrm{Ca}$ and $\mathrm{Mg}: \mathrm{Ca}$ core measurements are within the range of the measured non-vent fish values, while bythitid core Mn:Ca values are even higher than those of the non-vent fish. Conversely, the core measurements for $\mathrm{Sr}: \mathrm{Ca}$ and $\mathrm{Cd}: \mathrm{Ca}$ are depleted relative to the rest of the otolith, and in the case of $\mathrm{Sr}$, gradually increase for the entire lifespan of the fish. The bythitid $\mathrm{Sr}$ and $\mathrm{Cd}$ core measurements are again similar to the values displayed by the non-vent fish. The similarity of bythitid core measurements to those of non-vent fish suggests that Thermichthys hollisi spends the initial portion of its life away from hydrothermal vents, in an environment similar to that experienced by non-vent deep-sea and slope species. This hypothesis is consistent with the lack of size structure within observed bythitid populations on the East Pacific Rise. T. hollisi is known to be viviparous, and if young bythitids are indeed born away from the vents, the migration of gravid females may represent a previously unknown export of carbon away from the ecosystem.

\subsection{Summary and Future Directions}

This study provides the first ever examination of otolith chemistry of hydrothermal vent-endemic fish. The chemical composition of hydrothermal fluids 
within the fishes' habitat appears to influence the chemical composition of the otoliths. This differences between vent and non-vent otoliths are most noticeable when examining $\mathrm{Sr}: \mathrm{Ca}, \mathrm{Ba}: \mathrm{Ca}$, and $\mathrm{Mg}: \mathrm{Ca}$ ratios. In general, it appears that Thermarces cerberus is experiencing greater exposure to hydrothermal fluids than Thermichthys hollisi, as evidenced by higher element:Ca ratios. This is not unexpected due to the habitat preferences exhibited by the different species, with $T$. cerberus most often observed among diffuse flow communities and $T$. hollisi having a seemingly more peripheral habitat. The similar patterns of $\mathrm{Ba}: \mathrm{Ca}$ and $\mathrm{Sr}: \mathrm{Ca}$ signatures in the individuals examined suggest that $T$. cerberus may live in cohorts that experience the same habitat conditions throughout their lifetime. An examination of additional zoarcid otoliths from a variety of vent sites would help to support this hypothesis. Interestingly, otolith chemistry provides the first evidence suggesting that $T$. hollisi does not begin its life within the venting environment, but rather spends some portion of its early life in non-vent environments similar to those experienced by typical deep-water or shelf-dwelling species, and then migrates back to the ridge system. This extent of this hypothesized migration may affect dispersal, resulting in distinct genetic population structures between regions where the fish are found.

Further examination of strontium isotopes, in particular $\delta^{87} \mathrm{Sr}$ of T. cerberus otoliths, may elucidate the origins of the unusually high Sr:Ca ratios, and the relative contribution of vent generated strontium to the otolith composition. Strontium isotopes are often utilized as paleothermometers, and further investigation into the influence of temperature on the $\mathrm{Sr}: \mathrm{Ca}$ otolith values within vent fish is warranted. Hart and Blusztjan 
(1998) utilized Sr:Ca within a hydrothermal vent clam shell to reconstruct a temperature history within which there appeared evidenced of increased temperature during eruptive events. It may be possible to reconstruct similar temperature histories using otolith $\mathrm{Sr}: \mathrm{Ca}$, provided a suitable exchange coefficient can be determined. In combination with aging studies, these data may indicate the feasibility of vent fish otoliths to track eruptive events or dramatic chemical changes of hydrothermal fluid chemical composition, particularly if fish from spatially distinct sites show similar spikes in Sr:Ca. Higher resolution analyses of the otolith can be undertaken to discern more complex patterns within the otolith and may prove useful in understanding how hydrothermal fluid exposure translates into elemental incorporation. 


\section{Chapter 3 References}

Bath GE, Thorrold SR, Jones CM, Campana SE, McLaren JW, Lam JWH (2000) Strontium and barium uptake in aragonitic otoliths of marine fish. Geochim Cosmochim Acta 64(10): 1705-1714.

Brazner JC, Campana SE, Tanner DK (2004) Habitat Fingerprints for Lake Superior Coastal Wetlands Derived from Elemental Analysis of Yellow Perch Otoliths. Trans Amer Fish Soc 133: 692-704.

Buckman KL, Shank TM (in prep) Trophic ecology of the hydrothermal vent-endemic fish Thermichthys hollisi. Mar Ecol Prog Ser.

Campana SE (1999) Chemistry and composition of fish otoliths: pathways, mechanisms and applications. Mar Ecol Prog Ser 188: 263-297.

Campana SE, Nielsen JD (1985) Microstructure of fish otoliths. Can J Fish Aquat Sci 42(5): 1014-1032.

Carré M, Bentaleb I, Bruguier O, Ordinola E, Barrett NT, Fontugne M (2006) Calcification rate influence on trace element concentrations in aragonitic bivalve shells: Evidences and mechanisms. Geochim Cosmochim Acta 70: 4906-4920.

Childress JJ, Fisher CR (1992) The biology of hydrothermal vent animals: physiology, biochemistry, and autotrophic symbiosis. Oceanogr Mar Biol A Rev 30: 337-341.

Cohen DM, Rosenblatt RH, Moser HG (1990) Biology and description of a bythitid fish from deep-sea thermal vents in the tropical eastern Pacific. Deep-Sea Res 37(2): 267-283.

Cravo A, Foster P, Almeida C, Company R, Cosson RP, Bebianno MJ (2007) Metals in the shell of Bathymodiolus azoricus from a hydrothermal vent site on the MidAtlantic Ridge. Environ Int 33: 609-615.

Dorval E, Jones CM, Hannigan R, van Montfrans J (2007) Relating otolith chemistry to surface water in a coastal plain estuary. Can J Fish Aquat Sci 64: 411-424.

Edmond JM, Measures C, McDuff RE, Chan LH,Collier R, Grant B, Gordon LI, Corliss JB (1979) Ridge crest hydrothermal activity and the balances of the major and minor elements in the ocean: The Galapagos data. EPSL 46: 1-28.

Edmond JM, Von Damm KL (1985) Chemistry of ridge crest hot springs. Bull Biol Soc Wash 6: 43-47.

Elsdon TS, Gillanders BM (2002) Interactive effects of temperature and salinity on otolith chemistry: challenges for determining environmental histories of fish. Can J Fish Aquat Sci 59: 1796-1808.

Hart SR, Blusztajn J (1998) Clams as Recorders of Ocean Ridge Volcanism and Hydorthermal Vent Field Activity. Science 280(5365): 883-886.

Jones C (1986) Determining age of larval fish with the otolith increment technique. Fish Bull 84(1): 91-104.

Klinkhammer GP, Elderfield H, Edmond JM, Mitra A (1994) Geochemical implications of rare earth element patterns in hydrothermal fluids from mid-ocean ridges. Geochim Cosmochim Acta 58(23): 5105-5113. 
Martin GB, Thorrold SR (2005) Temperature and salinity effects on magnesium, manganese, and barium incorporation in otoliths of larval and early juvenile spot Leiostomus xanthurus. Mar Ecol Prog Ser 293: 223-232.

Micheli F, Peterson CH, Mullineaux LS, Fisher CR, Mills SW, Sancho G, Johnson GA, Linihan HS (2002) Predation structures communities at deep-sea hydrothermal vents. Ecol Mono 72(3):365-382.

Milton DA, Chenery SR (2001) Sources and uptake of trace metals in otoliths of juvenile barramundi (Lates calcarifer). J Exp Mar Biol Ecol 264: 47-65.

Morales-Nin B, Panfili J (2005) Seasonality in the deep sea and tropics revisited: what can otoliths tell us? Mar Fresh Res 56:585-598s.

Pester NJ, Butterfield DA, Foustoukos DI, Roe KK, King K, Shank TM, Seyfried Jr. WE (2008) The chemistry of diffuse-flow vent fluids on the Galapagos Rift $\left(86^{\circ} \mathrm{W}\right)$ :

Temporal variability and subseafloor phase equilibria controls. In: Lowell RP, Seewald J, Metaxas A, Perfit M (eds) Magma to Microbe: Modeling Hydrothermal Processes at Oceanic Spreading Centers AGU Geophysical Monograph 178, 123-144.

Ravizza G, Blusztajn J, Von Damm KL, Bray AM, Bach W, Hart SR (2001) Sr isotope variations in vent fluids from 9 $9^{\circ} 46^{\prime}-9^{\circ} 54^{\prime} \mathrm{N}$ East Pacific Rise: Evidence of a nonzero-Mg fluid component. Geochim Cosmochim Acta 65(5): 729-739.

Richardson CA, Peharda M, Kennedy H, Kennedy P, Onofri V (2004) Age, growth rate and season of recruitment of Pinna nobilis (L) in the Croatian Adratic determined from Mg:Ca and Sr:Ca shell profiles. J Exp Mar Biol Ecol 299: 1-16.

Rio M, Roux M, Renard M, Schein (1993) Chemical and Isotopic Features of Present Day Bivalve Shells from Hydrothermal Vents or Cold Seeps. Palaios 7(4): 351360.

Rosenblatt RH, Cohen DM (1986) Fishes living in deepsea thermal vents in the tropical eastern Pacific, with descriptions of a new genus and two new species of eelpouts (Zoarcidae). Trans San Diego Soc Nat Hist 21(4): 71-79.

Rosenthal Y, Field MP, Sherrell RM (1999) Precise Determination of Element/Calcium Ratios in Calcareous Samples Using Sector Field Inductively Coupled Plasma Mass Spectrometry. Anal Chem 71(15) 3248-3253.

Rouxel O, Shanks III WC, Bach W, Edwards KJ (2008) Integrated Fe- and S-isotope study of seafloor hydrothermal vents at East Pacific Rise $9-10^{\circ} \mathrm{N}$. Chem Geol 252: 214-227.

Sancho G, Fisher CR, Mills S, Micheli F, Johnson GA, Lenihan HS, Peterson CH, Mullineaux LS (2005) Selective predation by the zoarcid fish Thermarces cerberus at hydrothermal vents. Deep-Sea Res I 52:837-844.

Shank TM, Fornari DJ, Von Damm KL, Lilley MD, Haymon RM, Lutz RA (1998) Temporal and spatial patterns of biological community development at nascent deep-sea hydrothermal vents (950’N, East Pacific Rise). Deep-Sea Res II 45: 465-515.

Shirai K, Kawashima T, Sowa K, Watanabe T, Nakamori T, Takahata N, Amakawa H, Sano Y (2008) Minor and trace element incorporation into branching coral Acropora nobilis skeleton. Geochim Cosmochim Acta 72: 5386-5400. 
Stecher III HA, Krantz DE, Lord III CJ, Luther III GW, Bock KW (1996) Profiles of strontium and barium in Mercenaria mercenaria and Spisula solidissima shells. Geochim Cosmochim Acta 60(18): 3445-3456.

Sturgeon RE, Willie SN, Yang L, Greenberg R, Spatz RO, Chen Z, Scriver C, Clancy V, Lam JW, Thorrold S (2005) Certification of a fish otolith reference material in support of quality assurance for trace element analysis. J anal At Spectrom 20: 1067-1071.

Swan SC, Geffen AJ, Gordon JDM, Moralis-Nin B, Shimmield T (2006) Effects of handling and storage methods on the concentrations of elements in deep-water fish otoliths. J Fish Biol 68: 891-904.

Tyler PA, Young CM (1999) Reproduction and dispersal at vents and cold seeps. J Mar Biol Assoc UK 79(2): 193-208.

Van Dover CL (2000) The Ecology of Deep-Sea Hydrothemal Vents. Princeton University Press, Princeton, NJ. 424pp.

Von Damm KL (1995) Controls on the Chemistry and Temporal Variability of Seafloor Hydrothermal Fluids. In: Humphris SE, Zierenberg RA, Mullineaux LS, Thomson RE (eds) Seafloor Hydrothermal Systems Physical, Chemical, Biological, and Geological Interactions. AGU pp 222-247.

Von Damm KL, Lilley MD (2004) Diffuse Flow Hydrothermal Fluids from 950'N East Pacific Rise: Origin, Evolution and Biogeochemical Controls. In: Wilcock WSD, DeLong EF, Kelley DS, Baross JA, Cary SC (eds) The Subseafloor Biosphere at Mid-Ocean Ridges. AGU, Washington, DC pp.245-268.

Vrijenhoek RC (1997) Gene Flow and Genetic Diversity in Naturally Fragmented Metapopulations of Deep-Sea Hydrothermal Vent Animals. J Hered 88(4): 285293.

Walther BD, Thorrold SR (2006) Water, not food, contributes the majority of strontium and barium deposited in the otoliths of a marine fish. Mar Ecol Prog Ser 311: 125130.

Wisshak M, Correa ML, Gofas S, Salas C, Taviani M, Jakobsen J, Freiwald A (2009) Shell architecture, element composition, and stable isotope signature of the giant deep-sea oyster Neopycnodonte zibrowii sp. from the NE Atlantic. Deep-Sea Res I 56: 374-407.

Yoshinaga J, Nakama A, Morita M, Edmond JS (2000) Fish otolith reference material for quality assurance of chemical analyses. Mar Chem 69: 91-97. 


\title{
Chapter Four
}

\section{A preliminary exploration of gene expression in the hydrothermal vent}

\author{
fish Thermichthys hollisi
}

\begin{abstract}
Time-lapse photography and in situ electrochemistry were utilized to characterize Thermichthys hollisi habitats. An exploration of the expression of genes that may be responsive to changing and stressful habitat conditions was undertaken. Data indicated that $T$. hollisi are preferentially utilizing fish holes where there are elevated temperatures and sulfide levels, and depleted oxygen levels in comparison to ambient bottom water. A fragment of $\mathrm{Cu}, \mathrm{Zn}$ superoxide dismutase was successfully amplified from $T$. hollisi mRNA, but there were no differences in expression levels between tissue types or among individuals for the small sample set examined. Recommendations for future deep-sea gene expression studies are given.
\end{abstract}

\subsection{Introduction}

Hydrothermal vents on the East Pacific Rise are characterized by the production and emission of hot, acidic, sulfide- and metal-rich hydrothermal fluids. These fluids are enriched in hydrogen sulfide and metals such as copper, iron, cadmium, manganese, and zinc, and are depleted in oxygen in comparison to the surrounding deep water (Von Damm, 1995). Life at hydrothermal vents is able to exist due to the presence of chemical species such as hydrogen sulfide, methane and iron within the vent fluids. Reduced chemicals provide the energy for chemoautotrophic microbial communities to fix carbon, forming the basis of the trophic network within the vent ecosystem (Fisher et al., 1990). Yet the presence and composition of hydrothermal fluids also poses numerous challenges to the metazoan communities that exist in these environments (Childress \& Fisher 1992). Hydrogen sulfide, necessary for the metabolism of chemoautotrophs at vents, is a potent toxin for other organisms. It interfers with cytochrome c oxidase function, thereby 
disrupting aerobic respiration, and reduces oxygen transport by reacting with hemoglobin (reviewed in Grieshaber \& Völkel, 1998). High concentrations of heavy metals within the environment can be detrimental to an organism if they build up within the tissues. Their presence can facilitate the production of reactive oxygen species (ROS) and free radicals both in the water column and within the organisms themselves. Though ROS are a natural by-product of aerobic metabolism, they can be detrimental to organism health if they are produced faster than they are eliminated, leading to oxidative stress. ROS production can be facilitated by exposure to heavy metals, and if exposure is not reduced, ROS can damage DNA, destroy cell integrity, impair enzyme function, and lead to the production of additional ROS (Di Giulio et al., 1989; Aruoma, 1998; Valko et al., 2005). Hypoxia, a lack of sufficient dissolved oxygen, can lead to additional stress for an organism, and in the extreme may lead to a shut-down of aerobic respiration (Grieshaber et al., 1994). Additionally, vent fauna must be able to cope with elevated and fluctuating temperatures within their chaotic habitat, which may affect enzyme function and efficiency (Dahlhoff \& Somero, 1991).

Vent-endemic fauna must be able to either limit their exposure to potential toxins within hydrothermal fluids, or possess adaptations to ameliorate the effects of exposure to these chemicals. Adaptations can be behavioral (at the simplest, swimming or crawling to a more amenable habitat), structural/physical (tubes or mucous providing a barrier), or at a cellular level (possessing novel proteins or enzymes tolerant of a range of conditions) (Grieshaber and Völkel, 1998; Hagerman, 1998; Van Dover, 2000). Numerous studies have been conducted regarding how vent fauna tolerate the range of conditions and 
substances that they are exposed to (Arp \& Childress, 1983; Powell \& Somero, 1986; Dahlhoff \& Somero, 1991). Of particular interest due to the habitat characteristics of venting environments are stress-response genes, those that encode for proteins responsible for the elimination of excess metals, hydrogen sulfide, ROS within the cells, and that are frequently up-regulated in response to negatively changing water conditions. These genes include those that code for hypoxia inducible factor, heat-shock proteins, metallothioneins, and antioxidants such as superoxide dismutase, glutathione peroxidase, catalase, and glutathione reductase. Metallothioneins (MT) are low molecular weight, cysteine-rich proteins found in most eukaryotes that are involved in metal handling, homeostasis and detoxification (Tanguy et al., 2003; Capasso et al., 2003; Laurie, 2004). They have been studied in hydrothermal vent mussels from the Mid-Atlantic Ridge and East Pacific Rise (Hardivillier et al., 2004; Bebbiano et al., 2005; Hardivillier et al., 2006). Antioxidant enzyme activity is of particular interest at vents due to the enriched metal concentration within the hydrothermal fluids, and has been examined in a range of invertebrates, including Alvinellid polychaetes, mussels and shrimp (Bebbiano et al., 2005; Marie et al., 2006; Company et al., 2006; Gonzalez-Rey et al., 2007; Company et al., 2007; Shin et al., 2009). Vent invertebrates are known to bioaccumulate metals present within hydrothermal fluids in their tissues (Rousse et al, 1998; Kádár, 2005; Demina \& Galkin, 2008). Upper level predators such as vent-endemic fish must also be adapted to deal with not only habitat variability and stressors, but also the potential bioaccumulation, especially of heavy metals, that can occur through consumption of vent invertebrates. To date, there have been few studies centered on the vent-endemic 
vertebrates despite their importance in structuring the community through predation (Micheli et al., 2002; Sancho et al., 2005), and even fewer investigating metazoan gene expression responses to varying environmental conditions (Denis, et al., 2002; Faure, et al., 2005; Sato et al., 2005), though interest in this aspect of vent ecology continues to grow as scientists attempt to predict how species around the world will change in response to pollution and changing habitat conditions and to better understand how these genes may be related to health and diseases of all species (Shin et al., 2009). This knowledge is equally important to the understanding of how vent systems function on the EPR, as well as how they relate to similar communities around the world.

This study seeks to describe Thermichthys hollisi habitat usage and characteristics and undertakes a preliminary investigation of the expression of stress response genes within this species.

\subsection{Methods}

\subsubsection{Fish Collection and Preservation}

Thermichthys hollisi individuals were collected from L vent using a thrusterpowered suction sampler mounted on the submersible Alvin as previously described. The first fish was captured at approximately 1530 GMT, and weights were released for ascent to the surface at 2020 GMT. The bythitids were alive for the majority of the ascent (lasting approximately two hours); death was estimated to occur within the last $500 \mathrm{~m}$ of ascent, presumably from complications due to changes in pressure. Immediately upon the sub's recovery to the ship, the fish were transferred to chilled seawater and 
stored in the walk-in cold room until dissection. Time between initial capture and the onset of dissection was at least eight hours. Subsamples of liver, muscle and gill tissue were excised from each fish and preserved in RNALater (Ambion) as per the manufacturer's instructions. Preserved samples were then frozen at $-80^{\circ} \mathrm{C}$ for transport to the shore-based lab and long-term storage.

\subsubsection{Electrochemical Measurements}

Physico-chemical parameters of Thermichthys hollisi habitat were measured using in situ voltammetry using solid state gold-amalgam $(\mathrm{Au} / \mathrm{Hg})$ working microelectrodes. Briefly, these electrodes consisted of a $100-\mu \mathrm{m}$ gold wire housed inside polyethylether ketone (PEEK) tubing and plated with mercury (Brendel and Luther 1995; Luther et al. 1999). They were operated within the DSV Alvin through the use of Analytical Instrument Systems, Inc. (AIS) DLK-SUB analyzer (AIS-ISEA I) connected to a laptop computer (Nuzzio et al. 2002). A solid state reference (Ag/AgCl) electrode and counter (Pt) electrode were attached to the Alvin basket in ambient seawater, while the working $(\mathrm{Au} / \mathrm{Hg})$ electrodes and temperature probe were housed inside a Delrin or titanium wand, along with a thermocouple (Luther et al. 2001a; Luther et al. 2001b). In situ electrochemical scans were collected in a program of up to ten to twenty individual scans lasting 1.5-3 minutes and later analyzed onboard ship by member of G. Luther's lab (U. Delaware). Cyclic voltammetry, at a scan rate of $2000 \mathrm{mV} \mathrm{s}^{-1}$, was used for all measurements. Each scan process consisted of an electrode cleaning step with a holding potential of $-1.0 \mathrm{~V}$ for five seconds, a conditioning step where the initial potential $-0.05 \mathrm{~V}$ 
was held for two seconds, and the measurement step where the electrochemical scan was collected from $-0.05 \mathrm{~V}$ to $-1.8 \mathrm{~V}$ to $-0.05 \mathrm{~V}$. Detection of multiple analytes included $\mathrm{O}_{2}$ (detection limit, denoted as $\mathrm{DL}=\sim 3-5 \mu \mathrm{M}), \mathrm{H}_{2} \mathrm{~S}(\mathrm{DL}=0.2 \mu \mathrm{M})$, and other $\mathrm{S}(-\mathrm{II})$ species

such as polysulfides $\left(\mathrm{S}_{\mathrm{x}}{ }^{2-}, \mathrm{DL}=0.2 \mu \mathrm{M}\right)$ and thiosulfate $\left(\mathrm{S}_{2} \mathrm{O}_{3}{ }^{2-}, \mathrm{DL}=\sim 30 \mu \mathrm{M}\right)($ Brendel and Luther 1995; Luther et al. 2001b; Luther et al. 2008; Mullaugh et al. 2008). When measurements around organisms were not collected, cleaning scans were conducted to prevent electrode fouling and to maintain the integrity of the electrode surface.

Measurements were taken during Alvin dives 4310, 4313 and 4317 at the L vent site. In situ temperature, oxygen, and free sulfide $\left(\mathrm{H}_{2} \mathrm{~S}+\mathrm{HS}^{-}\right)$measurements were collected at multiple locations where fish were observed (specifically collapsed lava surfaces or "fish holes" and aggregations at cracks in the basalt) (Figure 4.1). Samples were subsequently categorized as "within" (tip of wand below surface of basalt or as far into crack as possible), "edge" (on the lip of a basalt collapse pit), or "adjacent" (bare basalt within 1m of fish hole with no associated fauna) to sampled fish holes.

\subsubsection{Time-Lapse Photography}

The RatCam, a down-looking time-lapse digital-still camera obtained from the MISO facility (WHOI), was deployed for five days at the main fish hole at L vent.

Strobes attached to the side of the frame are angled to illuminate the field of view of the camera and are powered by a 24 volt Subsea battery (Deep-Sea Power and Light) (Figure 4.2). Images were acquired at approximately 3.5 minute intervals (exp 1/60sec, f-5.3). The RatCam system was acoustically guided and released to the seafloor using a wire 
from the ship, and once on bottom, positioned over the fish hole using the submersible DSV Alvin (Jan 28, 2007 dive 4313) and recovered at the end of deployment by releasing the drop weights (Feb 2, 2007 dive 4317). A Vemco ${ }^{\mathrm{TM}}$ temperature probe was placed in the "fish hole" for concurrent temperature measurements; however it was unable to be recovered.

The abundance and location of fish in each image were analyzed by hand, and fish were classified as either "within" or "outside" of the central collapse pit. Fish were categorized as "within" the hole if all or part of their body appeared below the level of the basalt crust (Figure 4.3). Fish that may have been associated with diffuse flow, but not swimming within the central hole were classified as "outside". 


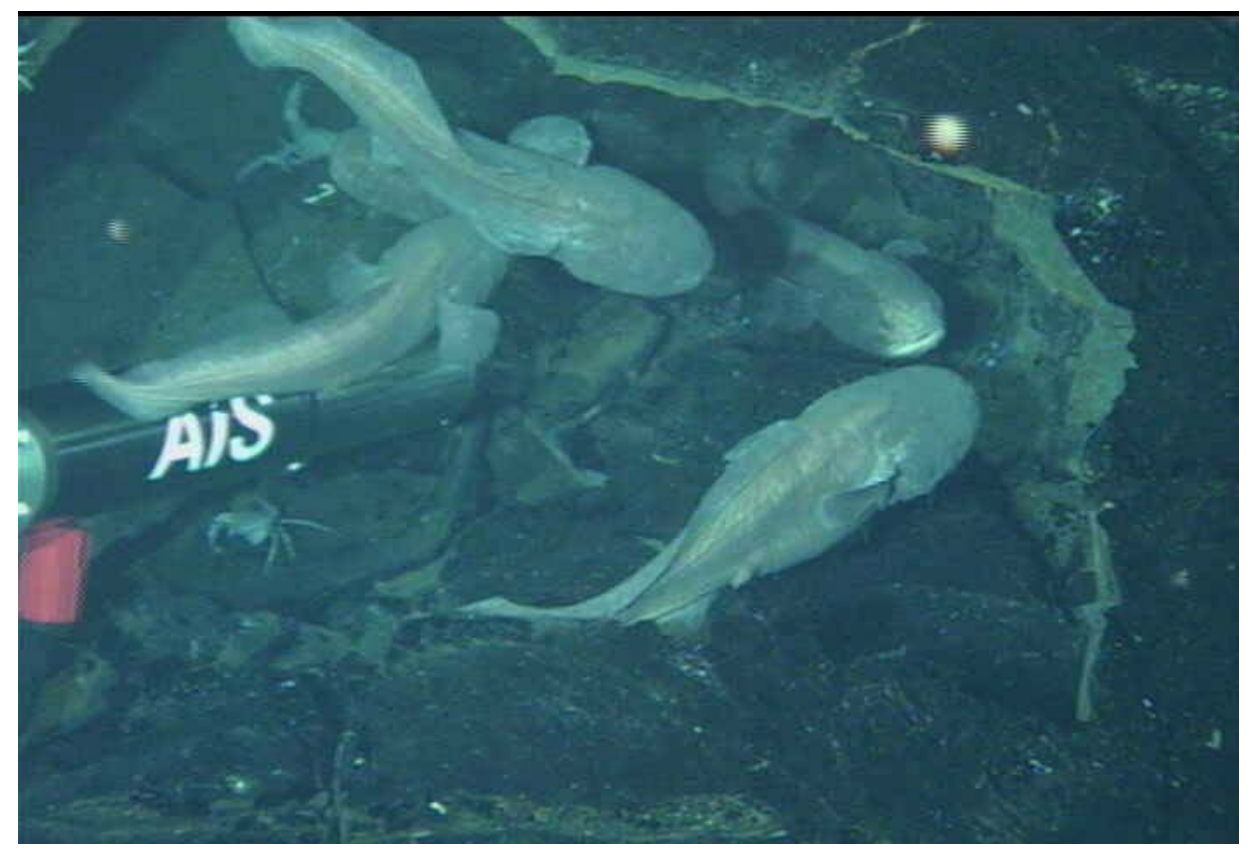

Figure 4.1 In situ electrochemical measurements being taken within a fish hole.

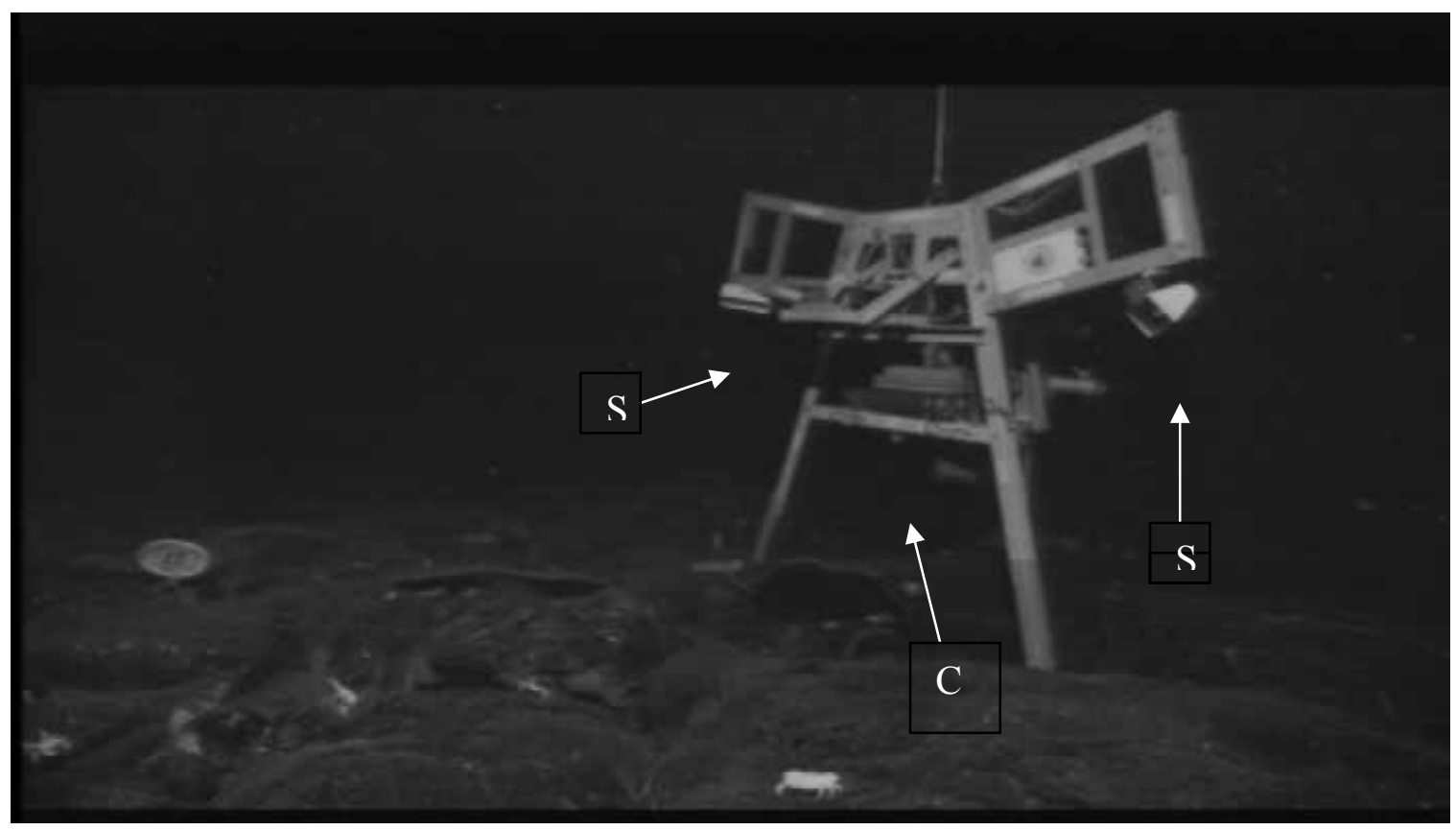

Figure 4.2 RatCam deployed on the seafloor over a fish hole. The strobes (S) and camera (C) are indicated by arrows. 


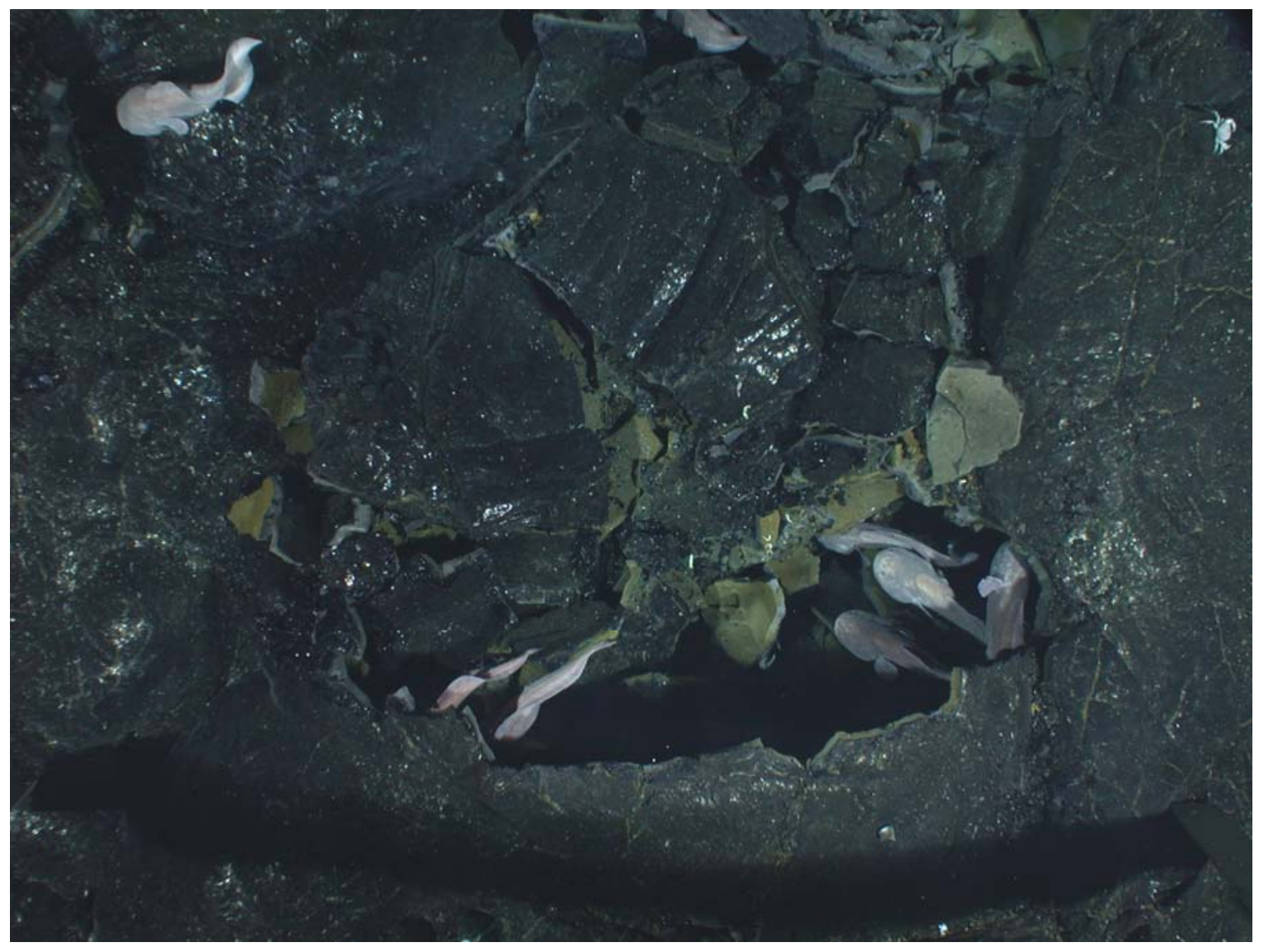

Figure 4.3 Example of image taken by the RatCam. In this image, with a field of view of $3.1 \times 2.3$ meters, there are six fish counted within the fish hole and two outside of it. 


\subsubsection{RNA Extraction and RT-PCR}

Total RNA was extracted from RNALater preserved gill, liver and muscle $T$. hollisi tissue using a Quiagen RNEasy kit according to the manufacturer's instructions for animal tissue using a rotor-stator homogenizer. Extractions were subsequently treated with an RNase-free DNase (Qiagen), which was heat inactivated at $75^{\circ} \mathrm{C}$ for 5 minutes. RNA extraction success was tested by running $1 \mu \mathrm{L}$ total RNA on a Nanodrop spectrophotometer (ThermoScientific), with results indicating that all samples contained nucleic acids; $260: 280$ ratios were within the range expected for RNA. $3 \mu \mathrm{L}$ of total RNA was reverse transcribed using iScript Select cDNA synthesis kit (Bio-Rad) according to

the manufacturer's instructions using the included oligo-dt primers. No-RT controls were also generated and amplified using Th18f \& Th18r primers under the semi-quantitative PCR conditions outlined below in order to ensure no DNA contamination.

Degenerate primers for multiple stress response genes were constructed from known teleost sequences downloaded from GenBank, or from published primer sets and tested using either genomic T. hollisi DNA extractions, liver cDNA or both under a variety of pcr conditions (Table 4.1). The pcr products were sequenced on an ABI capillary sequencer at the Josephine Bay Paul Center (Marine Biological Laboratory, Woods Hole, MA), analyzed using standard sequencing software, and compared to sequences in GenBank to determine if the correct gene had been amplified. Of the primers tested we were only able to successfully obtain fragments matching $\mathrm{Cu}, \mathrm{Zn}$-SOD sequences contained in GenBank. The successful primers are as follows ( $5^{\prime}$ to $\left.3^{\prime}\right)$ : CuZnSOD_1f ACT TCA ACC CYC AYR RYA AR and CuZnSOD_1r WCC TTC 
TCR TGR ATC ACC AT. A 236bp per product was obtained by combining $2 \mu \mathrm{L}$ template, $5 \mathrm{mM} \mathrm{MgCl}, 1 \mathrm{x}$ buffer, $0.1 \mathrm{mM}$ dNTPs, $0.5 \mu \mathrm{M}$ each of forward and reverse primer and 2.5 units Promega Flexi Taq in a $25 \mu \mathrm{L}$ reaction. A touchdown PCR was utilized as follows: an initial denaturation of 2 minutes at $94^{\circ} \mathrm{C}$ was followed by 14 cycles of 45 secs at $94^{\circ} \mathrm{C}, 45$ secs of a $-0.5^{\circ} \mathrm{C}$ decrease per cycle beginning at $55^{\circ} \mathrm{C}$, and 1 min at $72^{\circ} \mathrm{C}$; then 26 cycles of $45 \operatorname{secs}$ at $94^{\circ} \mathrm{C}, 45 \operatorname{secs}$ at $48^{\circ} \mathrm{C}$ and $1 \mathrm{~min}$ at $72^{\circ} \mathrm{C}$ with a final extension period of 5 min at $72^{\circ} \mathrm{C}$. Standard $18 \mathrm{~h}$ (AGG GTT CGA TTC CGG AGA GGG AGC CTG AGA AA) and 18k (CCC GTG TTG AGT CAA ATT AAG CCG CAG GC) primers (Hillis \& Dixon, 1991) were utilized to obtain a 632bp fragment of the $18 \mathrm{~s}$ small ribosomal subunit under the following pcr conditions: $94^{\circ} \mathrm{C}$ initial $2 \mathrm{~min}$ denaturation followed by 30 cycles of $94^{\circ} \mathrm{C}$ for 1 minute, $50^{\circ} \mathrm{C}$ for 45 seconds, $72^{\circ} \mathrm{C}$ for one minute with a final $72^{\circ} \mathrm{C}$ extension for 5 minutes. Thermichthys hollisi specific SOD and 18s primers were designed from the resultant sequences and are presented in Table 4.2. $2 \mathrm{ul}$ of cDNA was used for all subsequent PCR reactions. Semi-quantitative PCR was performed in order to compare expression levels of $\mathrm{Cu}, \mathrm{Zn}$-SOD between tissues (liver, gill, and muscle) within the same individual and between individuals from the same location using the same components as above. An initial $2 \mathrm{~min}$ denaturization at $94^{\circ} \mathrm{C}$ was followed by 35 cycles of $45 \mathrm{sec}$ at $94^{\circ} \mathrm{C}, 30 \mathrm{sec}$ at $56^{\circ} \mathrm{C}$, and $45 \mathrm{sec}$ at $72^{\circ} \mathrm{C}$ with a final extension period of 2 minutes at $72^{\circ} \mathrm{C}$. The pcr products were imaged on a $1.5 \%$ agarose gel stained with ethidium bromide and quantified using Kodak Imager software. All no-RT and negative controls were negative, indicating no DNA contamination. SOD levels were normalized to that of $18 \mathrm{~s}$ with the assumption that $18 \mathrm{~s}$ 
is expressed equally across all tissue types and are reported as relative fluorescent units. The SOD fragment was compared to other teleost nucleotide and amino acid sequences available from GenBank, and neighbor-joining trees (distance: total character difference, bootstrap x100) for both nucleotide and amino acids sequences were constructed using PAUP (ver. 4, Sinauer Associates), with an oyster (Crassostrea ariakensis) sequence utilized as an outgroup taxon.

Table 4.1 All primers tested. Forward primers are indicated by (F) preceding the primer sequence. Closest or most common matches are indicated, though it should be noted that most blast matches were less than 150bp sequence length and non-specific. Italicized matches are from unidirectional sequences (only one primer of the pair successfully sequenced) or single occurrence BLAST (Basic Local Alignment Search Tool, NCBI) search matches. Normal text indicates BLAST matches that occurred more than once.

\begin{tabular}{|c|c|c|}
\hline Predicted Gene Region & Primer sequence $5^{\prime}-3^{\prime}$ & Results \\
\hline \multirow[t]{13}{*}{ Metallothionein 1/A } & Met $12 \mathrm{f}(\mathrm{F})$ TCCATCTGGCTTTCTCTCGT & \multirow{5}{*}{$\begin{array}{l}\text { no amplification } \\
\text { random clones } \\
\text { putative CPSF-domain } \\
\text { protein } \\
\text { NADH dehydrogenase }\end{array}$} \\
\hline & met1 1f (F) CCCTTGGGTCCATTGTCTC & \\
\hline & met 1 3f (F) GCATCACCTGAGAACATGGA & \\
\hline & met 1 4r TTTTGCAGGAGCAGTTTGTG & \\
\hline & met 1 5r KAAMTKMATTTATTTCVACATYG & \\
\hline & met A 1f(F) TGGGTAGCCATATTTGAATGA & \multirow{3}{*}{$\begin{array}{l}\text { subunit } \\
\text { myosin light chain } \\
\text { Wee1-like protein }\end{array}$} \\
\hline & metA 2f (F) ATCCTGCAAGTGCTCCAACT & \\
\hline & metA 3r AGTTGGAGCACTTGCAGGAT & \\
\hline & met A 4r AGGGAATGGACTGCATTGTG & \multirow{2}{*}{$\begin{array}{l}\text { locus } \\
\text { isotocin and vasotocin }\end{array}$} \\
\hline & MT1.1f(F) MTGCAMKTGCACWAAYYGMY & \\
\hline & MT1.3f (F) GCGTGAAAGGGTCATGTTTT & \multirow{3}{*}{$\begin{array}{l}\text { major } \\
\text { histocompatability } \\
\text { complex } 2 \\
\text { poor sequence quality }\end{array}$} \\
\hline & Mt1.2r RYCRCARGWMTTSCCYWTRC & \\
\hline & Mt1.4f (F) AWKASTGGRMHHYGYAAYWG & \\
\hline \multirow[t]{4}{*}{ Metallothionein 2/B } & Met 2 1f (F) TGCACCTACTCACGAGGACA & \multirow{4}{*}{$\begin{array}{l}\text { random clones } \\
\text { myosin light chain } \\
\text { putatative } \\
\text { neurotransmitter }\end{array}$} \\
\hline & met $22 \mathrm{f}(\mathrm{F})$ AAAAGTGGGACCTGCAACTG & \\
\hline & met 2 3r CAAGKAASTGYATTTATTTCAA & \\
\hline & met B 1f(F) ATGGATCCKTGTGAATGCTCT & \\
\hline
\end{tabular}




\begin{tabular}{|c|c|c|}
\hline & met B 2f (F) TCCTGCAAGTGCTCAAACTG & \multirow{6}{*}{$\begin{array}{l}\text { receptor } \\
\text { Sphingosine-1- } \\
\text { phosphate receptor } 2 \\
\text { HLA-B associated } \\
\text { transcript } 5 \\
\text { cyclic nucleotide gated } \\
\text { channel alphas } \\
\text { EDG-S receptor } \\
\text { protein } \\
\text { poor sequence quality }\end{array}$} \\
\hline & met B 3f (F) TCTCTCTCATGCTGGCTTCA & \\
\hline & met B 4r AGCAACCTGATGGGACAAAA & \\
\hline & met B 5r AGGGAATCGACTGCATTGTC & \\
\hline & met2.1f (F) WRASTGGRRBYTGYMYTG & \\
\hline & met2.2r CAMWGGYKCCATYMCRMGRK & \\
\hline \multirow{6}{*}{$\begin{array}{l}\text { generic } \\
\text { metallothionein }\end{array}$} & MetX1 (F) aTGGAYCCITGYGARTGYWSIAARAC & \multirow{6}{*}{$\begin{array}{l}\text { no amplification } \\
\text { random clones } \\
\text { zinc fingers } \\
\text { protease } \\
\text { poor sequence quality }\end{array}$} \\
\hline & ${\text { MetX2a }{ }^{\mathrm{a}} \text { TTYTGIACRCTRTGIWSIACRACRGTYAY }}$ & \\
\hline & MetX3 $^{\text {a }}$ (F) GARTGYWSIAARACIGGIWSITGYAA & \\
\hline & MetX4 $4^{\mathrm{a}}$ ACRTTYCCITTYTGIACRCTRTGIW & \\
\hline & FishMTFW $^{\mathrm{b}}$ TGCYACCTGCAAGTGYACCAA & \\
\hline & Metx.1r CRCAKGWMTTSCCYTTRC & \\
\hline \multirow[t]{4}{*}{ Superoxide dismutase } & CuZnSOD1_f (F) ACTTCAACCCYCAYRRYAAR & \multirow{4}{*}{$\begin{array}{l}\text { random clones } \\
\mathrm{Cu}, \mathrm{Zn} \text { SOD } \\
\text { protein phosphatase } 2 \\
\text { regulatory subunit B }\end{array}$} \\
\hline & CuZnSOD1_r WCCTTCTCRTGRATCACCAT & \\
\hline & UniSOD1 $^{\mathrm{c}}(\overline{\mathrm{F}})$ CAYGGHTTCCATRTCCA & \\
\hline & UniSOD1r ${ }^{\mathrm{c}}$ ATGCCRATVACDCCRCAGGCC & \\
\hline \multirow{4}{*}{$\begin{array}{l}\text { Glutathione } \mathrm{S} \\
\text { transferase }\end{array}$} & GSTpi1 f (F) AAGAYGGTGACCTGGTSCTG & \multirow{4}{*}{$\begin{array}{l}\text { guanine nucleotide } \\
\text { binding protein }\end{array}$} \\
\hline & GSTpi1 r CCRTTGATGGGCAGTTTCTT & \\
\hline & GST theta (F) YATGMTSTACCTGGCTGASA & \\
\hline & GST theta CAYGCCTTGAGYTTGGGTCT & \\
\hline \multirow{4}{*}{$\begin{array}{l}\text { Hypoxia inducible } \\
\text { factor alpha }\end{array}$} & Hifla f(F) GYHTSGGBCTDRCWCAGWTY & \multirow{4}{*}{$\begin{array}{l}\text { no amplification } \\
\text { random clones }\end{array}$} \\
\hline & Hifla r YTGHGTYTCMASCCAMACAAS & \\
\hline & HIF4f $^{\mathrm{d}}(\mathrm{F})$ GTSCTSCACTGYACNGG & \\
\hline & HIF7r ${ }^{\mathrm{d}}$ CATNGCGAASAGCTTCTC & \\
\hline \multirow[t]{2}{*}{ Heat Shock Protein 70} & HSP70f (F) GGCACCACCTACTCCTGTGT & \multirow[t]{2}{*}{ no amplification } \\
\hline & HSP70r TTCCCTCCGTCTGAAATCAC & \\
\hline
\end{tabular}

a. Cousinou et al., 1999 b. Cho et al., 2008 c. Cho et al., 2006 d. Powell \& Hahn, 2002

Table 4.2 Thermichthys hollisi specific primers used for semi-quantitative RT-PCR.

\begin{tabular}{|l|l|l|}
\hline Target Gene & primer name & 5' $-3^{\prime}$ sequence \\
\hline $\mathrm{Cu}, \mathrm{Zn}$ SOD & ThSOD_f & AGACCTGGGGAATGTGACTG \\
\hline $\mathrm{Cu}, \mathrm{Zn}$ SOD & ThSOD_r & TCTGCCGATGATGGAGTAGG \\
\hline $18 \mathrm{~s}$ & Th18f & CCGCAGCTAGGAATAATGGA \\
\hline $18 \mathrm{~s}$ & Th18r & GATCGCTAGTTGGCATCGTT \\
\hline
\end{tabular}




\subsection{Results}

\subsubsection{Electrochemical measurements}

Fish hole chemical measurements indicated that these environments are chemically distinct from the surrounding ambient water. Within fish holes, the measured temperatures (Figure 4.4) ranged from $6-15^{\circ} \mathrm{C}\left(\right.$ mean $\left.10.54 \pm 2.3^{\circ} \mathrm{C}\right)$. Free sulfide (Figure 4.5) ranged from non-detectable to $53.5 \mu \mathrm{M}$ (mean $25.2 \pm 8.4 \mu \mathrm{M}$ ) and oxygen (Figure 4.6) ranged from non-detectable to $159 \mu \mathrm{M}$ (mean $35.8 \pm 23.1 \mu \mathrm{M}$ ). Electrochemical measurements taken on bare basalt outside of a fish hole averaged $4.2 \pm$ $6.3^{\circ} \mathrm{C}$, non-detectable sulfide, and $55.8 \pm 35.1 \mu \mathrm{M}$ dissolved oxygen, with all measurements for the "edge" of fish hole intermediate to those "within" and "adjacent". ANOVA with Bonferronni post-hoc test indicated significant differences $(p<0.001)$ between "within" and "edge"; and "within" and "adjacent"; but not between "edge" and "adjacent" measurements for both temperature and free sulfide. Due to the high variation within oxygen values, there were no significant differences found between the different sampling areas. With the exception of one set of scans, oxygen appears lower within fish holes than outside of them. 


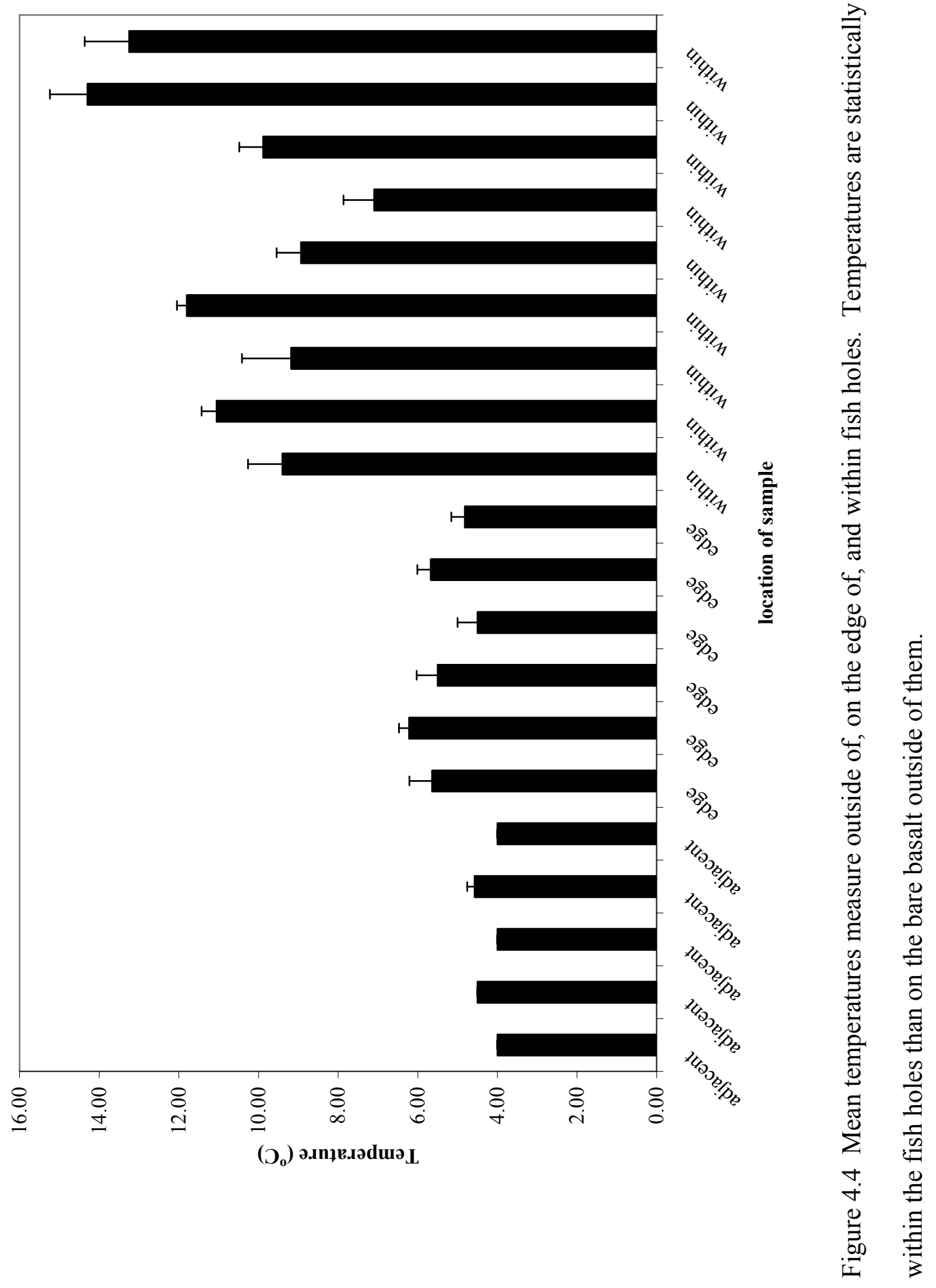




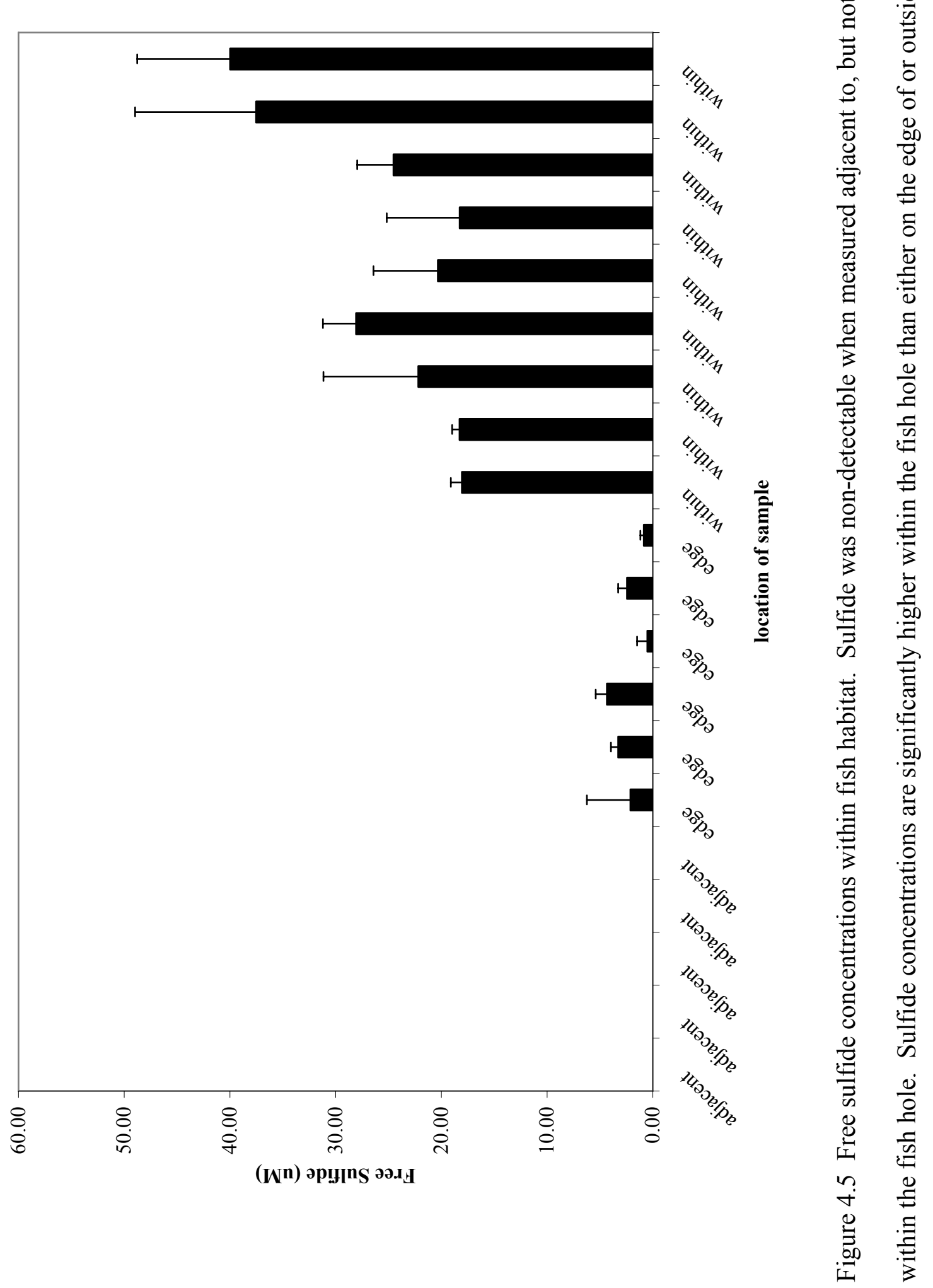




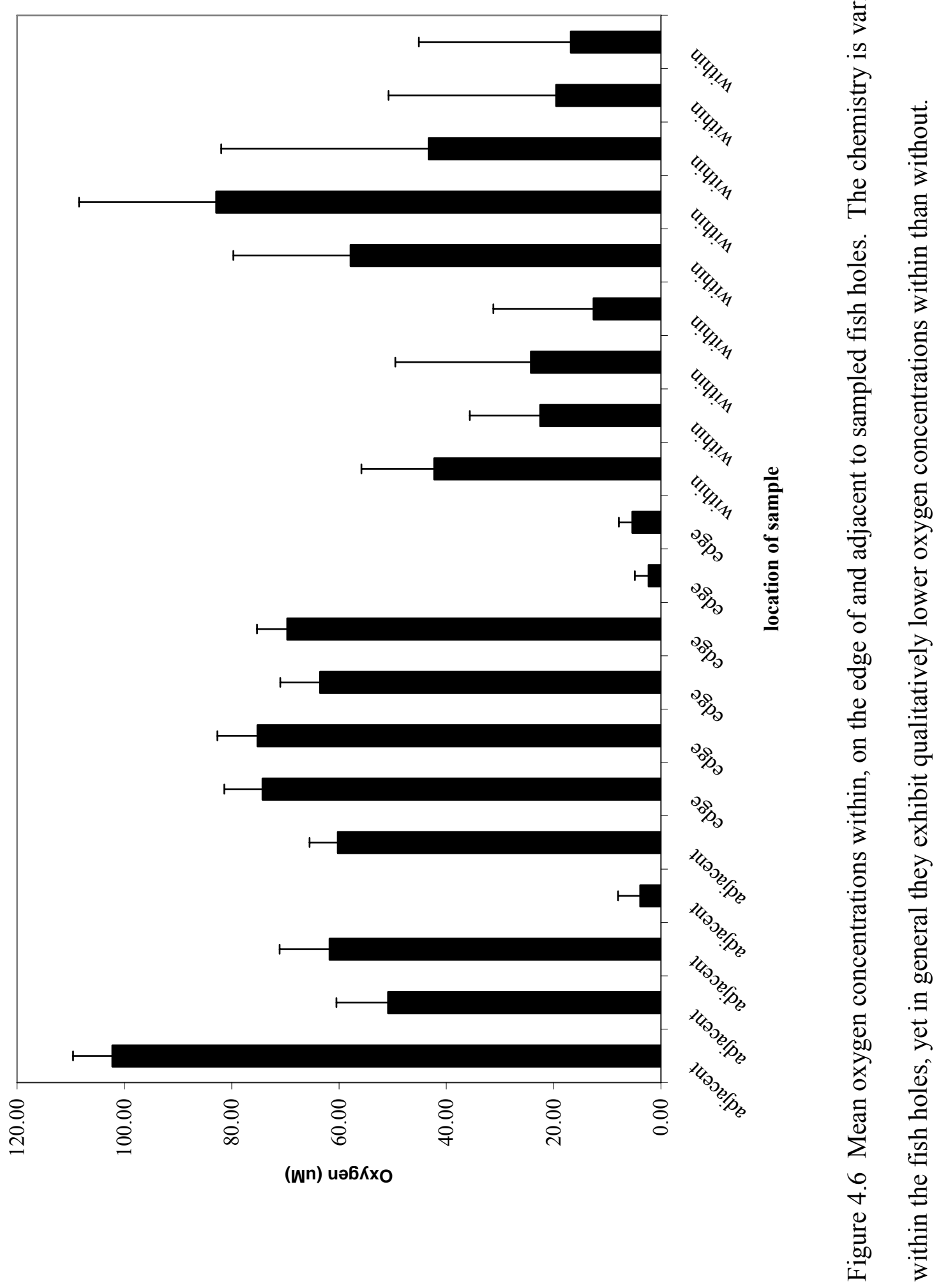




\subsubsection{Image analysis}

The time-lapse camera successfully imaged the central fish hole for approximately 2 days and 16 hours with a total of 1,024 images analyzed. During this time period there were on average significantly (t-test, $\mathrm{p}<0.001)$ more fish inside of the central hole (mean 3.7 fish/image) than outside of it (mean 2.7 fish/image) with a mean of 6.4 fish per image total (Figure 4.7). Other fauna observed included numerous bythograeid crabs (mean 4.1 per image) and the occasional octopod.

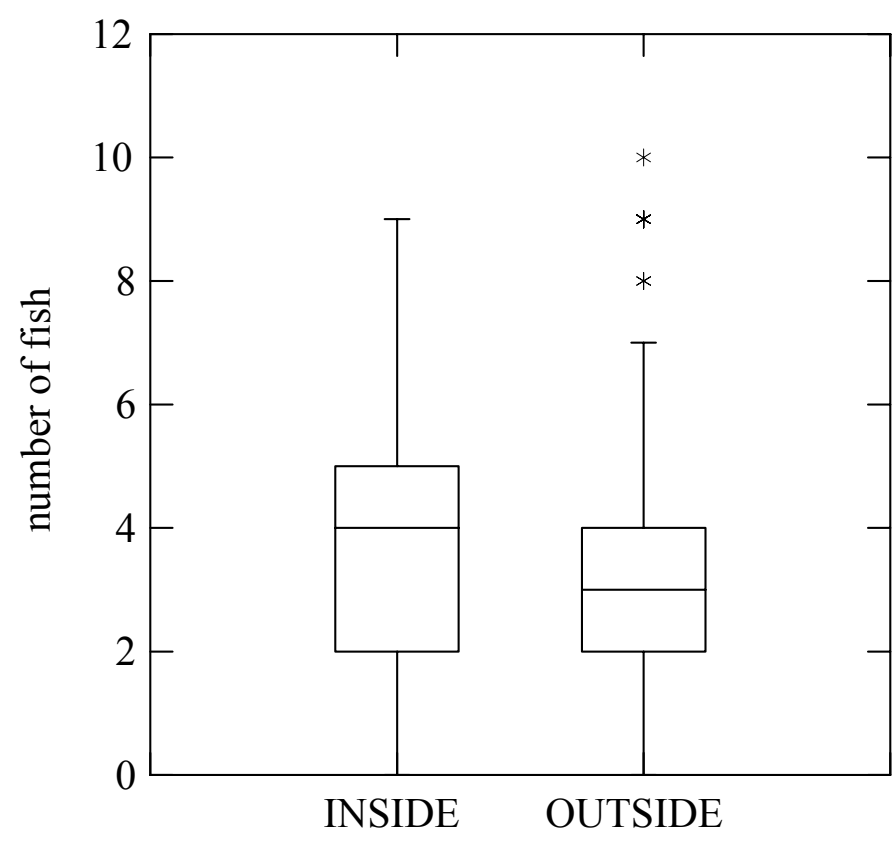

Fish Location

Figure 4.7 Median and range of Thermichthys hollisi individuals imaged inside of and outside of the central fish hole using the RatCam. "Inside" fish have all or part of their body below the level of the basalt crust at the edges of the fish hole. Asterisks are considered outliers. 


\subsubsection{Gene expression and relationship}

Primers were designed to amplify fragments of genes encoding for metallothioneins, superoxide dismutase, hypoxia inducible factor, heat shock proteins, and glutathione s transferase (Table 4.1). 17 forward and 12 reverse primers were tested for metallothioneins with some expected to be specific to a particular metallothionein isoform and others more generic. Numerous bands up to $900 \mathrm{bp}$ successfully amplified utilizing annealing temperatures ranging from $45-58^{\circ} \mathrm{C}$ with most amplification occurring near $50^{\circ} \mathrm{C}$. Over 20 bands were subsequently sequenced with most exhibiting nonspecific, short-sequence length matches to sequences in GenBank. Matches to vertebrate zinc fingers, HLA-B associated transcripts, and myosin light chain occurred more than once with $80 \%$ or less sequence similarity. Two sets of primers were tested for superoxide dismutase, one universal set and one specific to $\mathrm{Cu}, \mathrm{Zn} \mathrm{SOD}$. Numerous bands less than $600 \mathrm{bp}$ in length were obtained and 12 bands sequenced. Again most matches were non-specific, but a fragment of $\mathrm{Cu}, \mathrm{Zn} \mathrm{SOD}$ was obtained. One set of primers were tested for heat shock protein 70. At an annealing temperature of $50^{\circ} \mathrm{C}$ there was no amplification of T. hollisi, but there were non-specific bands amplified for T. cerberus. Two primer sets were tested specific to hypoxia inducible factor, only one of which yielded products (multiple bands $<500 \mathrm{bp}$ ) when annealing temperatures ranging from $48-55^{\circ} \mathrm{C}$ were utilized. Two of these bands were successfully sequenced but again yielded non-specific matches. Two primer sets targeting glutathione $\mathrm{S}$ transferase (GSTpi and GSTtheta respectively) were tested with only GSTpi primers amplifying under similar conditions to those outlined above. Multiple bands less than 700bp length 
were amplified, one of which when sequenced matched a guanine nucleotide binding protein with $>85 \%$ sequence similarity. RNA quality was not specifically assessed, and thus it is difficult to evaluate whether the number of short sequences obtained was due to partial RNA degradation or not.

Of the primers tested, we were only able to successfully obtain fragments for the target gene for $\mathrm{Cu}, \mathrm{Zn}$-SOD. T. hollisi partial SOD gene sequence shares an $81 \%$ pairwise similarity (51\% identical) in amino acid composition when compared with 15 other teleost, a shark, and an oyster $\mathrm{Cu}, \mathrm{Zn}-\mathrm{SOD}$ amino acid sequences (Figure 4.8). The nucleotide neighbor-joining tree generated from the SOD fragment indicates that the closest related SOD analyzed is that of Oreochromis mossambicus (Figure 4.9). The amino acid neighbor-joining tree (Figure 4.10) showed even less definition with no distinguishable relationship between $T$. hollisi, the other teleosts and the oyster outgroup. $\mathrm{Cu}, \mathrm{Zn}$ SOD gene expression was similar in all tissue types within an individual fish (Figure 4.11). There are no clear expression patterns among individuals (Figure 4.12). Although gill relative expression appears slightly elevated in comparison to that of the liver and muscle for two of the individuals, the difference is not significant, though small sample size diminishes the power of statistical tests. A larger sample size is necessary to assess the presence of significant expression patterns within the collected population. 


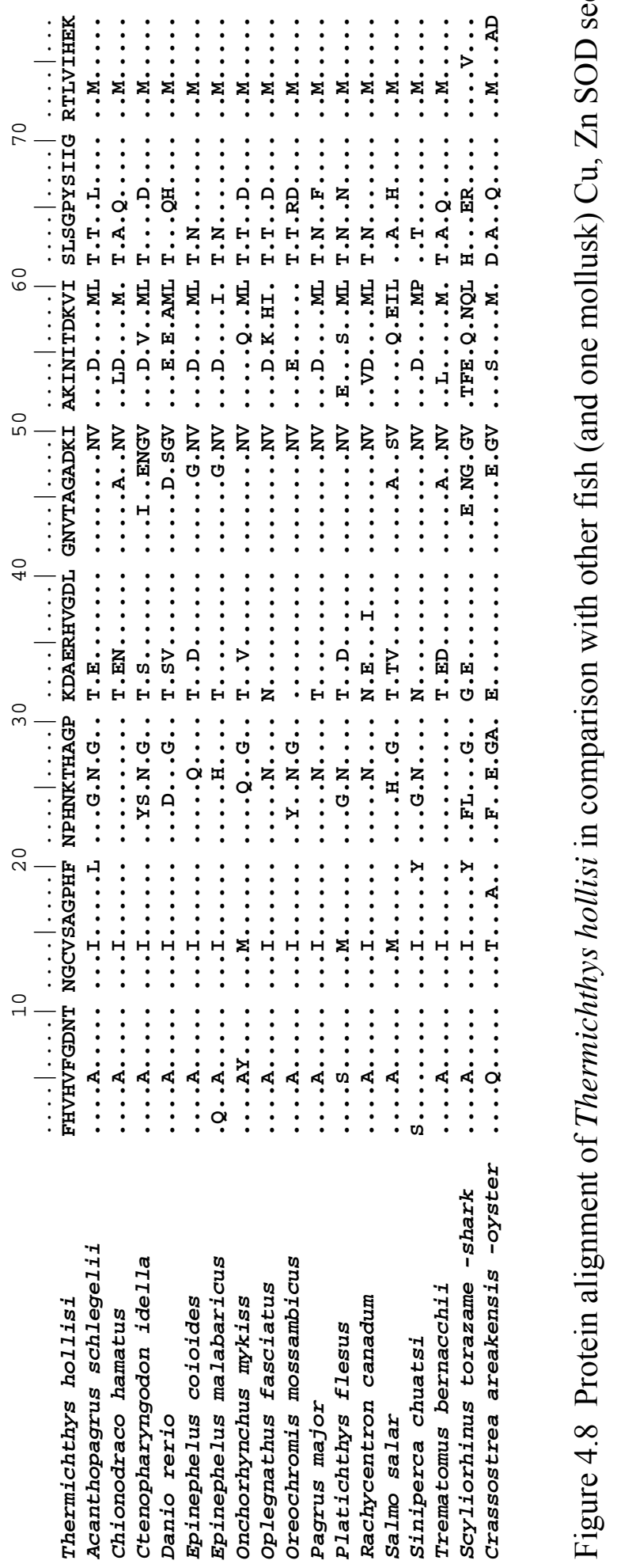




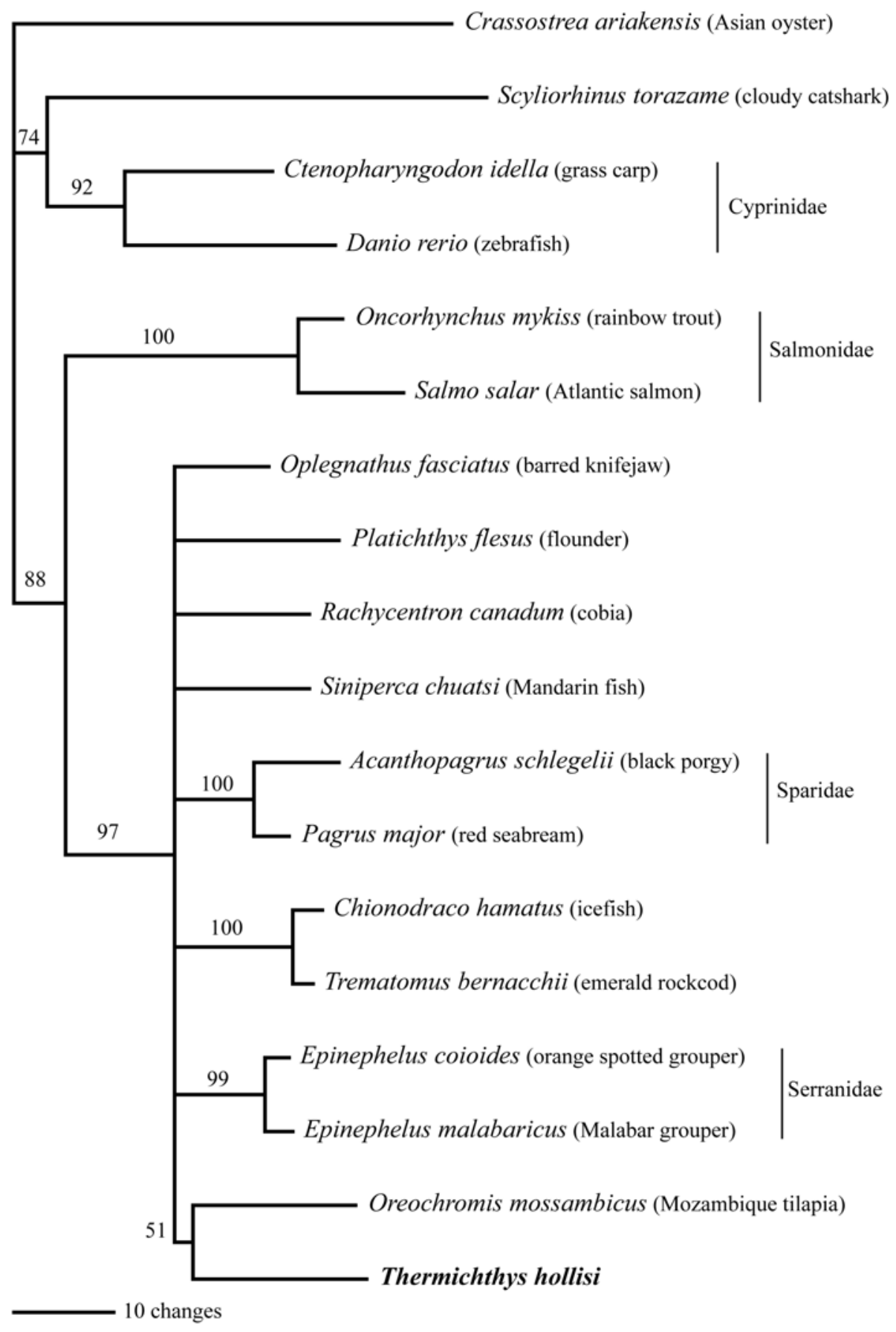

Figure 4.9 Neighbor-joining tree for fish $\mathrm{Cu}, \mathrm{Zn}$ superoxide dismutase nucleotide alignment (oyster outgroup). Bootstrap values are indicated at the nodes and branches occupied by individuals from the same family are marked on the right. 


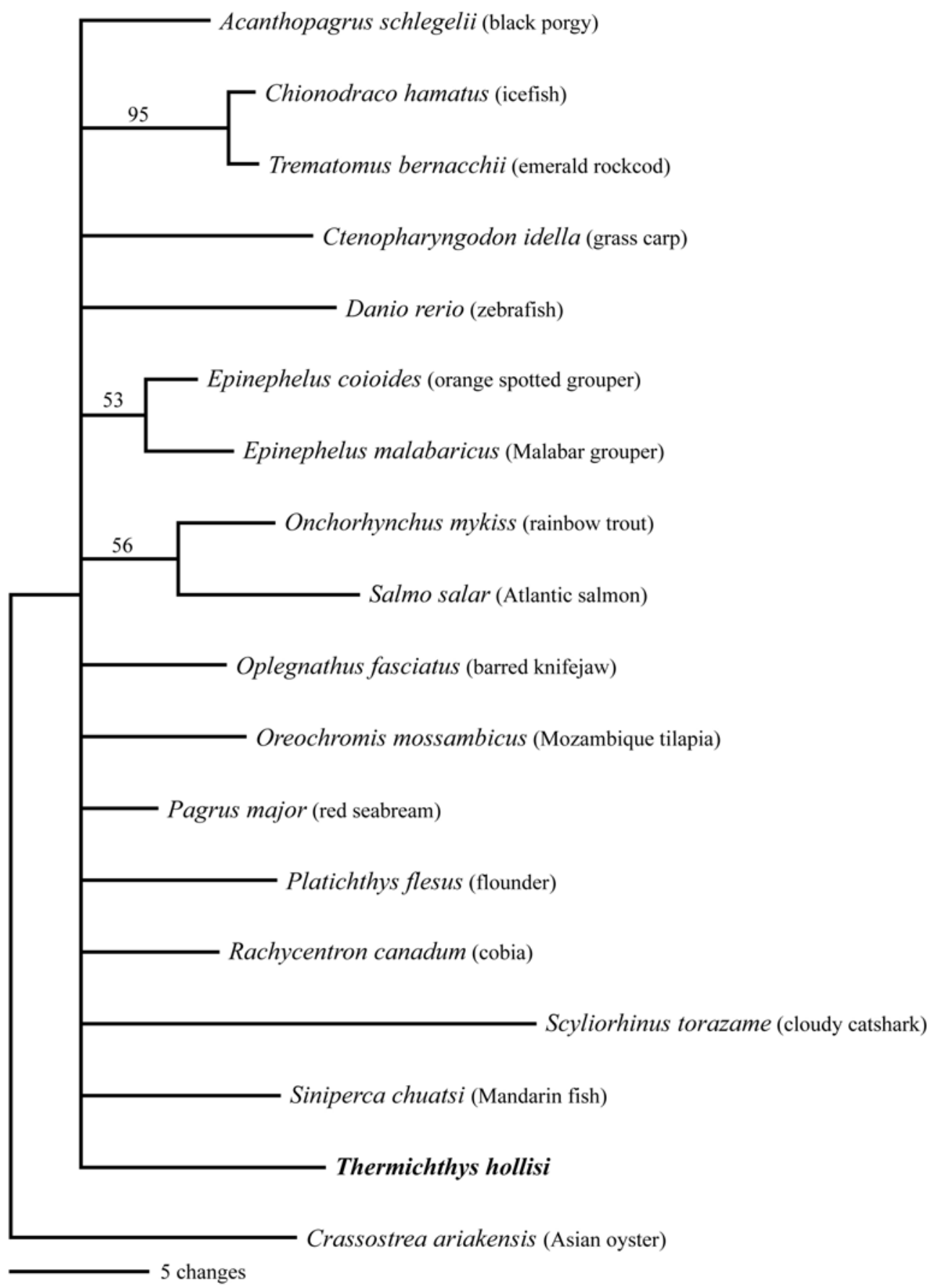

Figure 4.10 Neighbor-joining tree constructed from partial $\mathrm{Cu}, \mathrm{Zn}$-SOD amino acid fish sequences (oyster outgroup). Bootstrap values are indicated at the nodes. 
liver gill muscle

$\mathrm{Cu}, \mathrm{Zn} \mathrm{SOD}$

Figure 4.11 Example of pcr gel image. The upper panel indicates 18 s expression from Th5 and the lower panel indicates SOD expression. The levels of expression of both genes are similar over all tissue types.

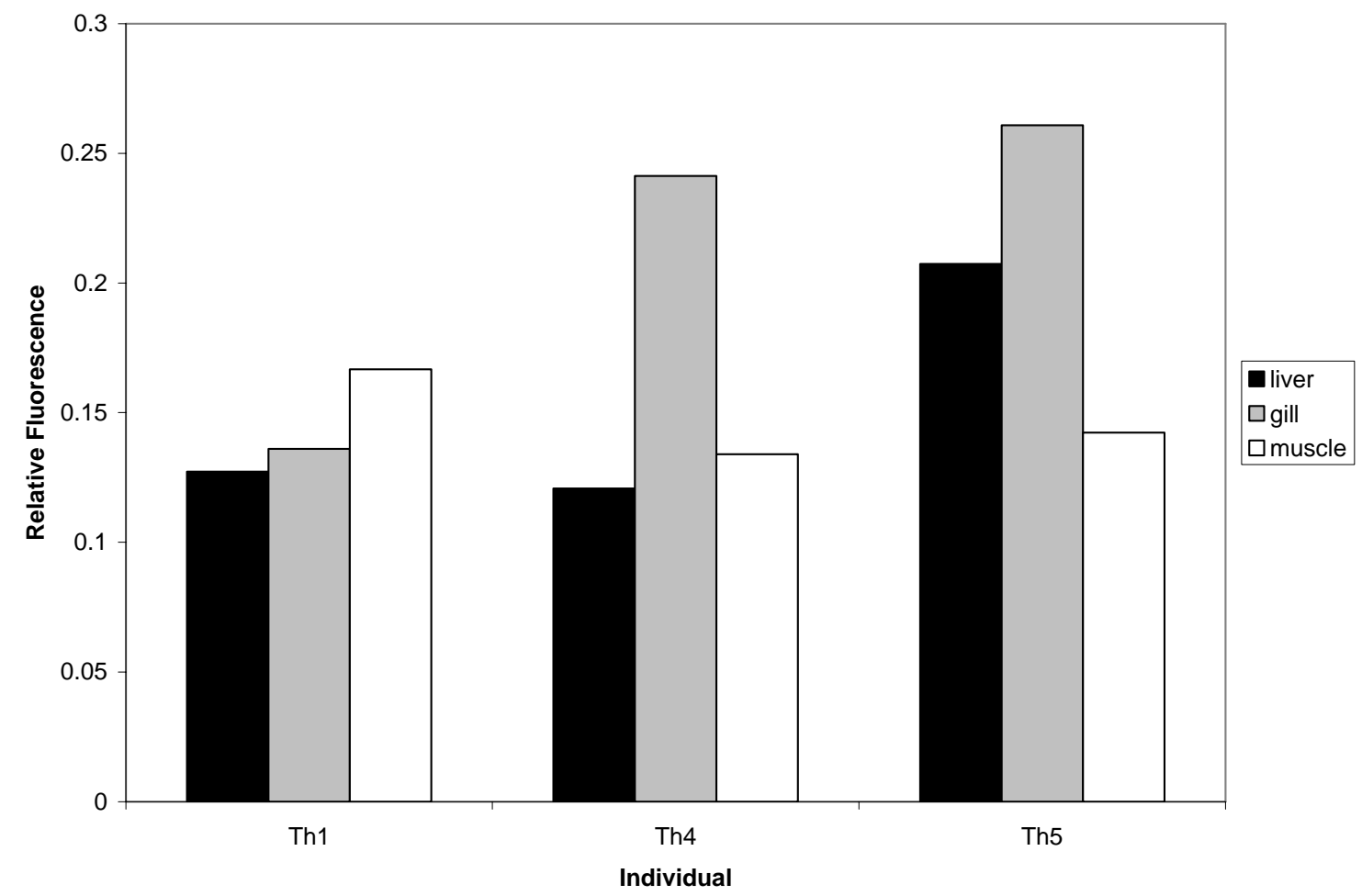

Figure 4.12 Relative SOD expression in liver gill and muscle tissue in three Thermichthys hollisi individuals, illustrating the lack of consistent differences among tissue types or between individuals. 


\subsection{Discussion}

The vent fish Thermichthys hollisi has been observed to live in the periphery of Eastern Pacific vent fields and in enigmatic aggregations in collapse pits and cracks termed "fish holes", where they had previously been considered relatively unexposed to hydrothermal fluid influence. A study of enzyme Tm on a single T. hollisi individual found the lactate dehydrogenase of $T$. hollisi is less functionally tolerant of elevated temperatures than that of Thermarces andersoni/cerberus, the other species of ventendemic fish on the East Pacific Rise, leading the investigators to hypothesize that $T$. hollisi is less well-adapted to live at vents (Dahlhoff et al., 1990). Despite this assumption, it has been shown through otolith chemistry (Buckman et al., in prep) that $T$. hollisi experiences a habitat with different chemical composition than would be considered typical for a deep-sea fish, and that the influence of hydrothermal fluids is evident throughout the majority of their lifespan.

These findings are supported by the current study. Electrochemical measurements indicated that fish holes are elevated in temperature and free sulfide concentration, and generally depleted in dissolved oxygen (at times near hypoxic levels) relative to water outside of the fish-hole, suggesting a greater influence of hydrothermal activity within the habitat than previously suspected. T. hollisi individuals are more likely to be found in association with fish holes than not. Time-lapse camera images indicated that mean numbers of fish were greater within the imaged fish hole than outside of it for the period of observation. These data may actually underestimate the number of fish associated with "fish holes" as imaged fish that were counted as outside of the fish 
hole may have been associated with nearby fissures or collapses and not the central hole. The combined chemistry and image data indicated that $T$. hollisi are preferentially choosing habitats and thus experiencing environmental conditions associated with exposure to hydrothermal fluid (elevated temperatures, levels of metals and sulfides, and decreased oxygen). As such, they are likely to harbor behavioral and/or gene level adaptations to their habitat conditions.

The amplified fragment of SOD from Thermichthys hollisi shares amino acid sequence similarities with characterized SOD from other teleosts (Figure 4.6), in accordance with previous work suggesting that this gene is well conserved (Cho et al., 2006; Nam et al., 2006). A neighbor-joining tree derived from the 236bp nucleotide fragment and available GenBank sequences indicated that $T$. hollisi $\mathrm{Cu}, \mathrm{Zn}-\mathrm{SOD}$ is most similar to that of Oreochromis mossambicus, a freshwater tilapia. Though some individuals from the same families (serranids, salmonids, sparids) clustered well together, the relationship between $T$. hollisi SOD and that of other fish species is not well resolved (see bootstrap values). Surprisingly, the cyprinids' SOD was found to be most closely related to that of a shark, and not to the other teleosts as would have been expected. The amino acid neighbor-joining tree is even less well-resolved; however, groups consisting of serranids, salmonids, and Antarctic fish continue to be present. The grouping of the Antarctic fish Trematonus bernacchii and Chionodraco hamatus is interesting in that it suggests that SOD may be evolving to suit the environment or habitat characteristics rather than along taxonomic lines. The current study is the first example of SOD from a 
deep-sea fish, and further investigation of the evolutionary relationships and conservation of teleost $\mathrm{Cu}, \mathrm{Zn}-\mathrm{SOD}$ with better taxonomic representation remains.

The results of the current exploration of $\mathrm{Cu}, \mathrm{Zn}$ SOD gene expression within Thermichthys hollisi tissues were inconclusive, yet they highlighted a number of conditions to consider when conducting future gene expression studies of vent fauna. Despite its use in the current study (due to the lack of consistent and correct amplification of other genes), SOD may not be an ideal gene with which to examine environmental stress, particularly when considered independent of other stress response genes. SOD is an integral component of the regulation of cellular ROS levels, catalyzing the transformation of the super oxide anion to $\mathrm{H}_{2} \mathrm{O}_{2}$ and $\mathrm{O}_{2}$, and through this process helping to decrease cell stress and damage (Fridovich, 1995). Yet SOD has been shown to actually decrease its activity upon initial exposure to heavy metals (whose presence facilitates the generation of ROS and oxidative stress) (Company et al., 2006; Lushchak et al., 2009). Organisms with chronic metal exposure in contrast may have elevated levels of SOD activity and transcription in comparison to unexposed individuals (Cho et al., 2006; Ruas et al., 2008). For oxidative stress response genes, a traditional assay of enzyme activity in combination with gene expression may prove to be more informative of levels of oxidative stress in vent fauna.

In addition, a different method of collection and preservation of vent fauna would greatly improve expression studies. Though we were able to successfully preserve, extract, reverse-transcribe and amplify RNA from specimens after their recovery from the seafloor, this method may confound future gene expression studies as it will be difficult 
to distinguish expression patterns related to the stresses from recovery to the surface from those caused by habitat conditions, especially for genes with rapid response times. Additionally, extended periods of time between collection and processing may lead not only to altered expression patterns, but also to RNA degradation, which will limit the methods that can be successfully utilized to analyze expression patterns. A mechanism for preserving fauna in situ would eliminate these problems, and would allow for better correlation of individual expression profiles with measured environmental variables. Such mechanisms have been developed for use with small vent invertebrates (Shank et al., in prep), but their use with vent fish may be currently unrealistic.

Of equal importance is the need to establish a comparative framework in order to assess organism response to variable conditions, and whether these responses are actually adaptive to the vent environment. Individuals of the same species should be collected from multiple sites, preferably with different habitat chemistry at each site, and gene expression and/or enzyme activity levels measured to assess between site differences. Comparisons can be made to expression levels and enzyme acitivities within and among other vent-endemic fish species in similar habitats to examine between species differences within the vent environment. It has been suggested that Thermarces cerberus may be better adapted to hydrothermal vent conditions than Thermichthys hollisi, and examining differences and similarities between gene nucleotide sequences as well as gene expression levels and enzyme activities is a first step towards examining this hypothesis. Enzyme sensitivity to changing conditions (temperature, pressure) can be measured within vent and non-ventfish tissues as in Dalhoff et al. (1990) to assess 
functionality under conditions that the fish may experience in disparate habitats. Ideally, controlled experiments comparing transcription-level responses of vent-endemic fish to those of closely related non-vent species in response to specific environmental parameters (hypoxia or controlled additions of cadmium) could be conducted. Though the current expenses and difficulties involved in capturing and maintaining live deep-sea fish for laboratory experiments may be prohibitive, a good initial step in addressing adaptation of vent vertebrates would be to compare and contrast enzyme functionality between closely related species and from there move on to an examination of in situ expression profiles.

\section{Summary and Future Work}

This study provided the first characterization of Thermichthys hollisi abundance, habitat use and environmental parameters. It was found that $T$. hollisi are significantly and preferentially associated with habitats featuring elevated temperatures and sulfide levels, and decreased oxygen concentration in contrast to the ambient bottom water, which may influence their physiological adaptations. $\mathrm{Cu}, \mathrm{Zn}$ SOD protein is similar to that of other organisms, and expression of this gene was observed in all tissue types. Further exploration and controlled experimentation of Thermichthys hollisi temperature tolerances and exposure to metals with coincident measurements of gene expression and enzyme activity will provide greater understanding of the physiological constraints and stresses experienced by vent endemic fish. 


\section{Chapter 4 References}

Arp AJ, Childress JJ (1983) Sulfide binding by the blood of the hydrothermal vent tube worm Riftia pachyptila. Science 219: 295-297.

Aruoma OI (1998) Free radicals, oxidative stress, and antioxidants in human health and disease. J Amer Oil Chem Soc 75(2): 199-212.

Bebbiano MJ, Company R, Serafim A, Camus L, Cosson RP, Fiala-Medoni A (2005) Antioxidant systems and lipid peroxidation in Bathymodiolus azoricus from MidAtlantic Ridge hydrothermal vent fields. Aquat Tox 75: 354-373.

Brendel PJ, Luther III GW (1995) Development of a gold amalgam voltammetric microelectrode for the determination of dissolved Fe, Mn, $\mathrm{O}_{2}$, and $\mathrm{S}$ (-II) in porewaters of marine and freshwater sediments. Environ Sci Technol 29: 751761.

Buckman KL, Thorrold SR, Shank TM (in prep) Otolith chemistry of hydrothermal ventendemic fish from the East Pacific Rise.

Capasso C, Carginale V, Scudiero R, Crescenzi O, Spadaccini R, Temussi PA, Parisi E (2003) Phylogenetic divergence of fish and mammalian metallothionein:

Relationships with structural diversification and organismal temperature. J Mol Evol 57(S1): s250-s257.

Childress JJ, Fisher CR (1992) The biology of hydrothermal vent animals: physiology, biochemistry, and autotrophic symbiosis. Oceanogr Mar Biol A Rev 30: 337-341.

Cho YS, Choi BN, Kim KH, Kim SK, Kim DS, Band IC, Nam YK (2006) Differential expression of $\mathrm{Cy} / \mathrm{Zn}$ superoxide dismutase mRNA during exposures to heavy metals in rockbream (Oplegnathus fasciatus). Aquaculture 253: 667-679.

Cho YS, Lee SU, Kim K-Y, Bang IC Kim DS, Nam YK (2008) Gene Structure and expression of metallothionein during metal exposures in Hemibarbus mylodon. Ecotox Environ Safety 71: 125-137.

Company R, Serafim A, Cosson R, Fiala-Médioni A, Dixon DR, Bebbiano MJ (2007) Adaptation of the antioxidant defence system in hydrothermal-vent mussels (Bathymodiolus azoricus) transplantedbetween two Mid-Atlantic Ridge sites. Mar Ecol 28: 93-99.

Company R, Serrafim A, Cosson R, Camus L, Shilito B, Fiala-Médioni A, Bebianno MJ. (2006) The effect of cadmium on antioxidant responses and the susceptibility to oxidative stress in the hydrothermal vent mussel Bathymodiolus azoricus. Mar Biol 148: 817-825.

Cousinou M, Dorado G, López-Barea J (1999) Amplification and cloning of cDNAS of cytochrome P4501A1 and metallothionein genes from Sparus aurata Linnaeus, 1758 and Liza aurata (Risso, 1810) by Race-PCR. Bol Inst Exp Oceanogr 15(14): 473-484.

Dahlhoff E, Schneidemann S, Somero GN (1990) Pressure-Temperature Interactions on $\mathrm{M}_{4}$-Lactate Dehydrogenases From Hydrothermal Vent Fishes: Evidence for Adaptation to Elevated Temperatures by the Zoarcid Thermarces andersoni, but not by the Bythitid, Bythites hollisi. Biol Bull 179: 134-139. 
Dahlhoff E, Somero GN (1991) Pressure and temperature adaptation of cytosolic malate dehydrogenases of shallow- and deep-living marine invertebrates: Evidence for high body temperatures in hydrothermal vent animals. J Exp Biol 159: 473-487.

Demina LL, Galkin SV (2008) On the Role of Abioginic Factors in the Bioaccumulation of Heavy Metals by the Hydrothermal Fauna of the Mid-Atlantic Ridge. Oceanology 48(6): 784-797.

Denis F, Vachoux C, Gauvry L, Salin C, Hardivillier Y, Cosson R, Laulier M (2002) Characterization and expression of a Bathymodiolus sp. metallothionein gene. Proceedings of the second international symposium on deep-sea hydrothermal vent biology. Cah Biol Mar 43(3-4): 329-332.

Di Giulio RT, Washburn PC, Wenning RJ, Winston GW, Jewell CS (1989) Biochemical responses in aquatic animal: A review of determinants of oxidative stress. Environ Toxicol Chem 8:1103-1112.

Faure B, Tanguy A, shillitio B, Jollivet D (2005) Adaptive polymorphisms and genes coalesce in the deep-sea hydrothermal mussel Bathymodiolus spp. Third International Symposium on Hydrothermal Vent and Seep Biology. p. 136.

Fisher CR, Kennicutt II MC, Brooks JM (1990) Stable Carbon Isotopic Evidence for Carbon Limitation in Hydrothermal Vent Vestimentiferans. Science 247(4946):1094-1096.

Fridovich I (1995) Superoxide radical and superoxide dismutases. Annu Rev Biochem 64: 97-112.

Gonzalez-Rey M, Serafin A, Company R, Bebianno MJ (2007) Adaptation to metal toxicity: a comparison of hydrothermal vent and coastal shrimps. Mar Ecol 28: 100-107.

Grieshaber MK, Hardewig I, Kreutzer U, Portner H-O (1994) Physiological and Metabolic Responses to Hypoxia in Invertebrates. Rev Physiol Biochem Pharmacol 125: 43-115.

Grieshaber MK, Völkel S (1998) Animal Adaptations for Tolerance and Exploitation of Poisonous Sulfide. Annu Rev Physiol 60: 33-53.

Hagerman (1998) Physiological flexibility; a necessity for life in anoxic and sulphidic habitats. Hydrobiologia 375/376: 241-254.

Hardivillier Y, Denis F, Demattei M-V, Bustamante P, Laulier M, Cosson R (2006) Metal influence on metallothionein synthesis in the hydrothermal vent mussel Bathymodiolus thermophilus. Comp Biochem Physiol C 143: 321-332.

Hardivillier Y, Leignel V, Denis F, Uguen G, Cosson R, Laulier M (2004) Do organisms living around hydrothermal vent sites contain specific metallothioneins? The case of the gunus Bathymodiolus (Bivalvia, Mytilidae). Comp Biochem Physiol C 139: 111-118.

Kádár E, Costa V, Martins I, Santos RS, Powell JJ (2005) Enrichment in trace metals (Al, $\mathrm{Mn}, \mathrm{Co}, \mathrm{Cu}, \mathrm{Mo}, \mathrm{Cd}, \mathrm{Fe}, \mathrm{Zn}, \mathrm{Pb}$, and $\mathrm{Hg}$ ) of macro-invertebrate habitats at hydrothermal vents along the Mid-Atlantic Ridge. Hydrobiologia 548: 191-205.

Laurie AD (2004) Quantitation of metallothionein mRNA from the New Zealand common bully (Gobiomorphus cotidianus) and its implications for biomonitoring. N Z J Mar Freshwat Res 38(5): 869-877. 
Lushchak OV, Kubrak OI, Lozinsky OV, Storey JM, Storey KB, Lushchak VI (2009) Chromium(III) induces oxidatives stress in goldfish liver and kidney. Aquat Toxicol 93: 45-52.

Luther III GW, Reimers CE, Nuzzio DB, Lovalvo D (1999) In situ deployment of voltammetric, potentiometric, and amperometric microelectrodes from a ROV to determine dissolved $\mathrm{O}_{2}, \mathrm{Mn}, \mathrm{Fe}, \mathrm{S}(-2)$, and $\mathrm{pH}$ in porewaters. Environ Sci Technol 33: 4352-4356.

Luther III GW, Glazer BT, Hohmann L, Popp JI, Taillefert M, Rozan TF, Brendel PJ, Theberge SM, Nuzzio DB (2001b) Sulfur speciation monitored in situ with solid state gold amalgam voltammetric microelectrodes: polysulfides as a special case in sediments, microbial mats and hydrothermal vent waters. J Environ Monit 3: 61-66.

Luther GW, Glazer BT, Ma S, Trouwborst RE, Moore TS, Metzger E, Kraiya C, Waite TJ, Druschel G, Sundby G, Taillefert M, Nuzzio DB, Shank TM, Lewis BL, Brendel PJ (2008) Use of voltammetric solid-state (micro)electrodes for studying biogeochemical processes: Laboratory measurements to real time measurements with an in situ electrochemical analyzer (ISEA) Mar Chem 108: 221-235.

Luther GW, Rozan TF, Taillefert M, Nuzzio DB, Di Meo C, Shank TM, Lutz RA, Cary SC (2001a) Chemical speciation drives hydrothermal vent ecology. Nature 410: 813-816.

Marie B, Genard B, Rees J-F, Zal F (2006) Effect of ambient oxygen concentration on activities of enzymatic antioxidant defences and aerobic metabolism in the hydrothermal vent worm, Paralvinella grasslei. Mar Biol 150: 273-284.

Micheli F, Peterson CH, Mullineaux LS, Fisher CR, Mills SW, Sancho G, Johnson GA, Linihan HS (2002) Predation structures communities at deep-sea hydrothermal vents. Ecol Mono 72(3):365-382.

Mullaugh KM, Luther III GW, Ma S, Moore TS, Yücel M, Becker EL, Podowski EL, Fisher CR, Trouwborst RE, Pierson, BK (2008) Voltammetric (micro)electrodes for the in situ study of $\mathrm{Fe}^{2+}$ oxidation kinetics in hot springs and $\mathrm{S}_{2} \mathrm{O}_{3}{ }^{2-}$ production at hydrothermal vents. Electroanal 20: 280-290.

Nam YK, Cho YS, Kim K-Y, Bang IC, Kim KH, Kim SK, Kim DS (2006) Characterization of copper, zinc superoxide dismutase from a cartilaginous shark species, Scyliorhinus torazame (Carcharhiniformes). Fish Physiol Biochem 32: 305-315.

Nuzzio DB, Taillerfert M, Cary SC, Reysenbach AL, Luther III GW (2002) In situ voltammetry at hydrothermal vents. In: Taillerfert M, Rozan T (Eds) Envrionmental Electrochemistry: Analyses of Trace Element Biogeochemistry, Am Chem Soc Sym Ser vol. 811, ACS, Washington, D. C., pp. 40-53.

Powell MA, Somero GN (1986) Adaptations to Sulfide by the Hydrothermal Vent Animals: Sites and Mechanisms of Detoxification and Metabolism. 171: 274-290.

Powell WH, Hahn ME (2002) Identification and Functional Characterization of HypoxiaInducible Factor $2 \alpha$ From the Estuarine Teleost, Fundulus heteroclitus: Interaction of HIF-2 $\alpha$ With Two ARNT2 Splice Variants. J Exp Zool 294: 17-29. 
Rousse N, Boulegue J, Geret F, Fiala-Medioni A (1998) Bioaccumulation of metals and detoxification processes within hydrothermal vent molluscs: the case of the bivalve Bathymodiolus sp. from the Mid-Atlantic Ridge. Biology of deep-sea hydrothermal vents. Cah Biol Mar 38(2): 137-138.

Ruas CBG, dos Santos Carvalho C, Selistre de Araújo HS, Espíndola ELG, Fernandes MN (2008) Oxidative stress biomarkers of exposure in the blood of cichlid species from a metal-contaminated river. Ecotoxicol Environ Safety 71: 86-93.

Sancho G, Fisher CR, Mills S, Micheli F, Johnson GA, Lenihan HS, Peterson CH, Mullineaux LS (2005) Selective predation by the zoarcid fish Thermarces cerberus at hydrothermal vents. Deep-Sea Res I 52:837-844.

Sato T, Matsuyama K, Miyake, Kitagawa, Kato C, Maruyama T (2005) Gene expression of a vestimentiferan tubeworm, Lamellibranchia Satsuma, under natural and laboratory conditions. Third International Symposium on Hydrothermal Vent and Seep Biology. p. 154.

Shank TM (in prep) A Deep Submergence Tool for the In-Situ Preservation of Living Organisms for Gene Expression Studies. Limnol Oceanogr Methods.

Shin DS, BiDonato M, Barondeau DP, Hura GL, Hitomi C, Berglund JA, Getzoff ED, Cary SC, Tainer JA (2009) Superoxide dismutase fromt eh Eukaryotic Thermophile Alvinella pompejana: Structures, Stability, Mechanism, and Insights into Amyotrophic Lateral Sclerosis. J Mol boil 385: 1534-1555.

Tanguy A, Boutet I, Riso R, Boudry P, Auffret M, Moraga D (2003) Metallothionein genes in the European flat oyster Ostrea edulis: a potential ecological tool for environmental monitoring? Mar. Ecol. Prog. Ser. 257: 87-97.

Valko M, Morris H, Cronin MTD (2005) Metals, Toxicity and Oxidative Stress. Curr Med Chem12(10): 1161 -1208

Van Dover (2000) Van Dover, C.L. 2000. The Ecology of Deep-Sea Hydrothemal Vents. Princeton University Press, Princeton, NJ. 424pp.

Von Damm KL (1995) Controls on the Chemistry and Temporal Variability of Seafloor Hydrothermal Fluids. In: Humphris SE, Zierenberg RA, Mullineaux LS, Thomson RE (eds) Seafloor Hydrothermal Systems Physical, Chemical, Biological, and Geological Interactions. AGU pp 222-247. 


\section{Chapter Five}

\section{Summary of Findings}

This thesis represents the first comprehensive ecological study of a hydrothermal vent-endemic fish. Thermichthys hollisi, a bythitid native to vents in the eastern Pacific, was the focus of this study; undertaken with the goals of elucidating the habitat preferences, trophic interactions, natural history, and potential adaptations to its environment. Gut content and stable isotope analyses provided the first direct evidence that $T$. hollisi feeds almost exclusively on other vent-endemic fauna, including brachyuran crabs, Alvinocaris shrimp, polychaetes, and the zoarcid fish Thermarces cerberus, placing T. hollisi within the upper if not the uppermost level of the trophic network within East Pacific Rise vent communities. As a top predator, T. hollisi may be influencing invertebrate community structure directly through predation on the invertebrates themselves and indirectly through removal of $T$. cerberus which is known to selectively prey upon limpest and amphipods.

Otolith isotope chemistry, in situ electrochemistry and time-lapse imagery all indicated that the preferred habitat of $T$. hollisi is comprised of collapse pits and fissures within the basalt, and that these areas are influenced by diffuse hydrothermal fluids despite being devoid of the vent invertebrate fauna typically associated with diffuse hydrothermal fluid flow. There are differences between the otolith chemistries of $T$. hollisi and T. cerberus which are reflective of their habitat preferences. T. cerberus appeared to experience greater exposure to the vent fluids and to spend the entirety of its 
life within the vent system whereas $T$. hollisi otoliths reflected less direct exposure to vent fluids and showed significantly different elemental signatures within the core of the otolith. T. hollisi core otolith element chemistry was strikingly similar to that of non-vent fish measured, suggesting that $T$. hollisi individuals are spending some portion of their larval or juvenile stages away from vent ecosystems (Figure 5.1). This behavior has implications not only for larval transport and population connectivity, but may also represent a previously unconsidered pathway for carbon exportation away from vents in the form of migrating gravid females.

As T. hollisi is exposed to hydrothermal fluids, it can be expected to harbor adaptations to life within the vent environment that may be analogous to invertebrate adaptations to sulfide exposure, elevated temperatures and metal exposure. In situ electrochemistry indicated that fish holes, where the T. hollisi is typically found, have elevated sulfide levels and temperatures, and decreased oxygen levels in comparison to uninhabited basalt areas outside of the hole, supporting the hypothesis that these fish may be have biochemical adaptations to enable them to exist and thrive in the vent environment. $\mathrm{Cu}, \mathrm{Zn}$ superoxide dismutase was amplified for the first time from a deepsea fish. The protein structure exhibited a number of differences when compared with other shallow-water teleost sequences, but major binding residues were conserved. The evolutionary relationship of $T$. hollisi $\mathrm{Cu}, \mathrm{Zn}$ SOD to other fish remainss unclear, and the addition of other vent and deep-sea fish species SOD sequences is necessary to interpret whether T. hollisi SOD protein structures are unique. Although SOD gene expression was evident in liver, gill, and muscle tissues from all individuals tested, there were no 
differences in expression levels evident that could be related to environmental parameters.

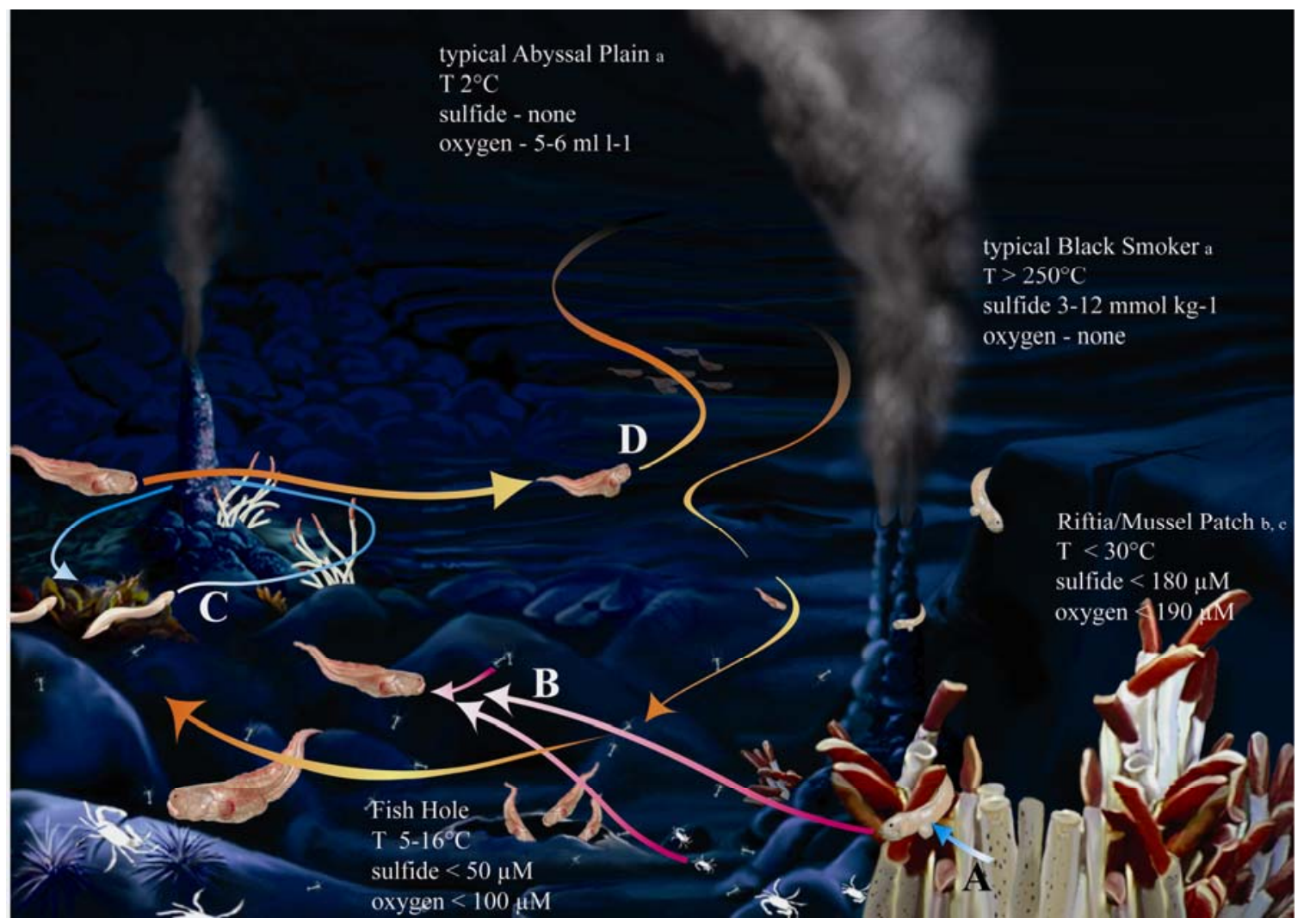

Figure 5.1 Composite illustration indicating generic habitat parameters experienced by vent-endemic fish on the East Pacific Rise as well as prey preference of zoarcids (A. limpets \& small crustaceans (Micheli et al., 2002; Sancho et al., 2005)); prey preferences of bythitids (e.g. B. shrimp, crabs, zoarcids); and proposed life history strategies of zoarcids (C. whole life within venting environment) and bythitids (D. early portion of life away from vent fluid influence).

a. Van Dover, 2000 b. Luther et al., 2008 c. Nees et al., 2008 


\section{Future Directions}

The studies undertaken as part of this thesis have advanced the current state of knowledge regarding East Pacific Rise hydrothermal vent-endemic fish ecological interactions with their habitat and their surrounding community. Yet, ecological knowledge of vent-endemic fish is far from complete, with numerous questions left to be clarified and answered. This work provides a building block for future studies regarding the ecology of vent-endemic vertebrates from all venting environments, not just the East Pacific Rise. Compound specific stable isotope studies are gaining popularity and may prove to be helpful in further elucidating trophic relationships within vent fields. Pond et al. (2008) studied fatty acid signatures within Thermarces cerberus to elucidate trophic interactions predicted from gut content studies. They discussed the hypothesized differences between invertebrate fatty acid acquisition at Atlantic versus Pacific vent sites, and comparative behavioral, feeding and isotopic studies of similar vent vertebrates between these disparate areas could be conducted to address unanswered questions regarding vent community fatty acid origins.

Otolith isotope analyses from the present study have illuminated interesting patterns within both species of vent fish examined. Strontium in particular bears further investigation as discussed in Chapter Three. The Sr:Ca values measured within the vent endemic fish otoliths, particularly within the zoarcids are higher than any previously measured Sr:Ca otolith values. The effects of temperature and environmental strontium concentrations on incorporation into the otolith bear further investigation, the results of 
which may provide further possibilities for studying and understanding the relationships defining otolith chemistry and the utility of vent fish otoliths as environmental proxies. The current otolith study has also provided a basis for vent fish population genetic studies. The similar chemical patterns over the lifetime of the fish examined suggest that they experience similar environmental chemical parameters and thus are perhaps restricted in their dispersal or living in cohorts that maintain "local" lineage groups in association with specific vent fields or sets of neighboring vent fields. Population genetic studies would allow for further investigation of this hypothesis, and would add to the growing body of knowledge regarding vent fauna connectivity, dispersal, and recruitment.

Genetic studies need not be restricted to population genetics. Molecular phylogenetic approaches can also help elucidate evolutionary relationships between vent fauna around the world. The family Zoarcidae, members of which are seemingly ubiquitous in both the non-vent deep-sea and in venting environments may be a good candidate for exploring questions regarding radiation and evolution in the deep-sea. The current work proved that gene expression studies within venting environments are feasible with careful design and improved sampling procedures. As discussed in Chapter Four, in combination with studies of gene sequence similarity and evolution in related species, gene expression studies of vent fish may help to answer questions regarding how vent fauna are adapted to take advantage of their habitat when they do not appear to differ physically from other fish species. Population genomics (reviewed in Neilsen et al., 2009) may provide another tool for learning about adaptation within fish species. 
The presence of fish within hydrothermal venting areas has been noted for as long as vents have been studied. Yet, with a few notable exceptions, the majority of publications regarding vent fish have been restricted to species descriptions or observational notes. Vent fish are integral members of the community, and as such deserve further examination in order to truly understand vent ecosystem function and dynamics. As this thesis has shown, there are ample opportunities for studying hydrothermal vent-endemic fish beyond basic species identification, and the fields of vent vertebrate behavior, ecology, and evolution remain wide open for future study. 


\section{Chapter 5 References}

Luther GW, Glazer BT, Ma S, Trouwborst RE, Moore TS, Metzger E, Kraiya C, Waite TJ, Druschel G, Sundby G, Taillefert M, Nuzzio DB, Shank TM, Lewis BL, Brendel PJ (2008) Use of voltammetric solid-state (micro)electrodes for studying biogeochemical processes: Laboratory measurements to real time measurements with an in situ electrochemical analyzer (ISEA) Mar Chem 108: 221-235.

Micheli F, Peterson CH, Mullineaux LS, Fisher CR, Mills SW, Sancho G, Johnson GA, Linihan HS (2002) Predation structures communities at deep-sea hydrothermal vents. Ecol Mono 72(3):365-382.

Nees HA, Moore TS, Mullaugh KM, Holyoke RR, Janzen CP, Ma S, Metzger E, Waite TJ, Yücel M, Lutz RA, Shank TM, Vetriani C, Nuzzio DB, Luther III GW (2008) Hydrothermal vent mussel habitat chemistry, pre- and post-eruption at $9^{\circ} 50$ ' North on the East Pacific Rise. J Shell Res 27(1): 169-175.

Neilsen EE, Hemmer-Hansen J, Larsen PF, Bekkevold D (2009) Population genomics of marine fishes: identifying adaptive variation in space and time. Mol Ecol 18:3128-3150.

Pond DW, Fallick AE, Stevens CJ, Morrison DJ, Dixon DR (2008) Vertebrate nutrition in a deep-sea hydrothermal vent ecosystem: Fatty acid and stable isotope evidence. Deep-Sea Res I 55(12): 1718-1726.

Sancho G, Fisher CR, Mills S, Micheli F, Johnson GA, Lenihan HS, Peterson CH, Mullineaux LS (2005) Selective predation by the zoarcid fish Thermarces cerberus at hydrothermal vents. Deep-Sea Res I 52:837-844.

Van Dover CL (2000) The Ecology of Deep-Sea Hydrothermal Vents. Princeton University Press, Princeton, NJ. 424pp. 